\title{
Review
}

\section{A Narrative Review of COVID-19 Vaccines}

\author{
Barbaros Eroglu, Rina Fajri Nuwarda (D), Iqbal Ramzan and Veysel Kayser *(D)
}

Sydney Pharmacy School, Faculty of Medicine and Health, The University of Sydney, Sydney 2006, Australia; barbaros.eroglu@sydney.edu.au (B.E.); rnuw0385@uni.sydney.edu.au (R.F.N.); iqbal.ramzan@sydney.edu.au (I.R.)

* Correspondence: veysel.kayser@sydney.edu.au; Tel.: +61-2-9351-3391

\begin{abstract}
The COVID-19 pandemic has shaken the world since early 2020 and its health, social, economic, and societal negative impacts at the global scale have been catastrophic. Since the early days of the pandemic, development of safe and effective vaccines was judged to be the best possible tool to minimize the effects of this pandemic. Drastic public health measures were put into place to stop the spread of the virus, with the hope that vaccines would be available soon. Thanks to the extraordinary commitments of many organizations and individuals from around the globe and the collaborative effort of many international scientists, vaccines against COVID-19 received regulatory approval for emergency human use in many jurisdictions in less than a year after the identification of the viral sequence. Several of these vaccines have been in use for some time; however, the pandemic is still ongoing and likely to persist for the foreseeable future. This is due to many reasons including reduced compliance with public health restrictions, limited vaccine manufacturing/distribution capacity, high rates of vaccine hesitancy, and the emergence of new variants with the capacity to spread more easily and to evade current vaccines. Here we discuss the discovery and availability of COVID-19 vaccines and evolving issues around mass vaccination programs.
\end{abstract}

Keywords: COVID-19; COVID-19 vaccines; SARS-CoV-2; vaccination; vaccine hesitancy

\section{check for}

updates

Citation: Eroglu, B.; Nuwarda, R.F.; Ramzan, I.; Kayser, V. A Narrative Review of COVID-19 Vaccines. Vaccines 2022, 10, 62. https:/ / doi.org/10.3390/vaccines10010062

Academic Editor: Jorge H. Leitão

Received: 29 November 2021

Accepted: 29 December 2021

Published: 31 December 2021

Publisher's Note: MDPI stays neutral with regard to jurisdictional claims in published maps and institutional affiliations.

Copyright: (c) 2021 by the authors. Licensee MDPI, Basel, Switzerland. This article is an open access article distributed under the terms and conditions of the Creative Commons Attribution (CC BY) license (https:// creativecommons.org/licenses/by/ $4.0 /)$.

\section{Introduction}

In December 2019, Chinese authorities notified the World Health Organization (WHO) of a cluster of unusual pneumonia cases in Wuhan, of an unknown viral aetiology. The cause of the cases was subsequently identified as a new type of coronavirus, later named Severe Acute Respiratory Syndrome Coronavirus 2 (SARS-CoV-2), and the disease caused by this virus was named Coronavirus Disease 2019 (COVID-19) [1]. In March 2020, WHO declared the COVID-19 outbreak a pandemic and warned governments globally to take all the necessary measures to prevent its spread [2]. Due to its high transmission rates, governments and public health agencies worldwide adopted public awareness campaigns and enforced social distancing restrictions, to minimize person-to-person transmission of the virus. Despite many efforts to contain the spread of the disease, including mandatory face mask wearing in public places, cancelling or limiting the number of people at gatherings and implementing lockdowns in many countries, the overall number of COVID-19 cases has exceeded 250 million worldwide with over 5.1 million deaths as of 29 November 2021 [3]. The severity of the pandemic led many scientists worldwide to focus on finding ways to treat the disease. Discovering and developing vaccines to fight COVID-19 has been the main objective of researchers and pharmaceutical companies. This review discusses the key elements of the SARS-CoV-2, COVID-19 disease, vaccines that have been developed very rapidly and are now commercially available and the pipeline of new vaccine candidates that are yet to enter the commercial arena. Even after two years, the COVID-19 pandemic continues as a major public health concern. Thus, providing a contemporary review of currently available and emerging COVID-19 vaccines globally would be a useful addition to the literature on the COVID-19 pandemic.

Key topics that are included in this review include: 
Background on COVID-19 pandemic as well as on beta-coronaviruses more generally, clinical overview of COVID-19, traditional and contemporary vaccine discovery platforms, classes of COVID-19 vaccines and key current and emerging COVID-19 vaccination themes like universal availability and affordability, vaccine hesitancy and the outlook for novel COVID-19 vaccines to tackle emerging variants.

This is not the first instance in the 21st century that a new and dangerous coronavirus has made the headlines. The first time that viruses from the coronavirus family shocked the world was in 2003 when a beta-coronavirus (SARS-CoV) caused an outbreak in China and spread to four other countries, causing more than 700 deaths with around $50 \%$ mortality in individuals over the age of 60 [4]. In 2012, another coronavirus, MERS-CoV, was identified causing Middle East respiratory syndrome (MERS), a deadly respiratory infection with a mortality rate of approximately $40 \%$ [5]. Even though SARS-CoV-2 is not as deadly as previous coronaviruses, it spreads far more efficiently than previous coronaviruses and has become a major global public health concern in only a couple of months.

SARS-CoV-2 is a member of the coronavirus family and belongs to the genera, betacoronaviruses. It shares a similar genome sequence with other well-known beta-coronaviruses, SARS-CoV ( 79\%) and MERS-CoV ( 50\%) [6]. It is a single-stranded RNA virus with a genome size of $\sim 30 \mathrm{~kb}$ and expresses 29 proteins including four main SARS-CoV-2 proteins: Spike $(\mathrm{S})$ protein, Envelope $(\mathrm{E})$ protein, Membrane $(\mathrm{M})$ protein and Nucleocapsid (N) protein [7] (Figure 1). S protein is the major surface protein of SARS-CoV-2 and is responsible for cell entry [8]. It is a 1273 amino acid trimeric protein with each monomer consisting of two subunits, S1 and S2 [9]. S1 subunit (aa14-685) consists of N-terminal domain, Receptor Binding Domain (RBD) and receptor-binding motif and facilitates the binding of the virus to the host cell receptor. S2 subunit (aa686-1273) comprises of fusion peptide, heptad repat 1 (HR1), heptad repeat 2 (HR2), transmembrane domain and cytoplasm domain, and mediates membrane fusion and entry into the host cell $[10,11]$. Structurally, S protein is classified as a class 1 viral fusion protein due to its characteristic heptad repeat region and $\mathrm{N}$-terminal or N-proximal fusion peptide and formation of a heterotrimeric six-helix bundle during the membrane fusion process [8]. S protein has also been shown to generate strong immune response and elicit neutralizing antibodies which has led vaccine developers to focus on utilizing not only the $S$ protein itself but also parts of the protein that trigger the immune response [12].

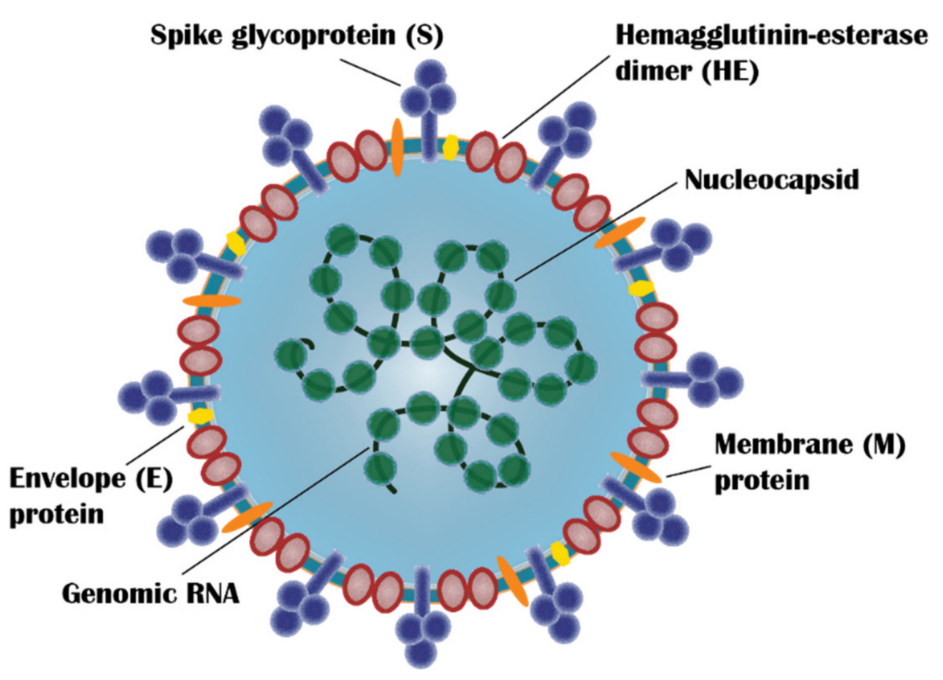

Figure 1. Schematic drawing of SARS-CoV-2 representing the major virus components: spike glycoprotein (S), hemagglutinin-esterase dimer (HE), membrane protein (M), envelope protein (E), nucleocapsid, and genomic RNA. (Redrawn by the authors based on Figure 2 in Ref. [13]). 


\section{SARS-CoV-2 Variants}

Mutation, alterations in one or several amino acids in the virus genome, can arise as a product of viral replication or natural selection. Although most of the amino acid changes are expected to be insignificant, some mutations yield differences in antigenicity, transmissibility, or virulence, resulting in new viral variants [14]. Throughout the COVID-19 pandemic, the emergence of new SARS-CoV-2 variants has been observed. The USA Centers for Disease Control and Prevention (CDC) has classified these as variants of interest, variants of concern, and variants of high consequence [15].

Variants that are predicted to impact the transmission, diagnostics, treatments, or immune evasion and are responsible for an increasing number of outbreaks are classified as variants of interest. Such a variant of interest may necessitate one or more additional public health actions, such as improved laboratory characterization, increased sequence surveillance, or epidemiological investigations to determine how easily the virus spreads to others, the severity of disease, therapeutic efficacy, and whether currently approved vaccines provide protection. A variant of interest (VOI) is classified as a variant of concern (VOC) if there is evidence for surge in transmissibility, increase in disease severity, and decreased efficacy of therapeutics or vaccines, or failure in its diagnosis. Variants of concern may require escalation of one or more public health responses, such as notification to WHO, efforts to control spread, increased testing, or studies to determine the efficacy of vaccines and treatments against the variant. Additional considerations such as developing new diagnostic tools or modifying treatments or vaccines may be necessary depending on the variant's characteristics. Compared to previously circulating variants, a variant of high concern has clear evidence that preventative efforts or medical countermeasures (MCMs) are much less effective [15].

As of November 2021, six previous VOI (Epsilon, Eta, Iota, Kappa, Zeta, and Lambda) and three previous VOC (Alpha, Beta, and Gamma) have been designated as Variants Being Monitored (VBM) by CDC. VOI or VOC may be moved to this list if its national and regional prevalence has decreased significantly and sustainably over time, or if other evidence suggests that the variant does not pose a major risk to public health. Mu variant, which was detected in Columbia in January 2021, was designated as VBM in September 2021; no SARS-CoV-2 variants are currently considered as being of high consequences and variants of interest (Table 1). On 26 November 2021, The Technical Advisory Group on SARS-CoV-2 Virus Evolution (TAG-VE) was convened to evaluate a newly detected the SARS-CoV-2 variant B.1.1.529. This variant was designated as a VOC, named Omicron, first reported in South Africa on 24 November 2021. The first confirmed infection with the Omicron variant was identified in a specimen obtained on 9 November 2021 [16].

Table 1. SARS-CoV-2 Variants Being Monitored (VBM) and Variants of Concern (VOC) $[15,17,18]$.

\begin{tabular}{|c|c|c|c|c|c|}
\hline & $\begin{array}{c}\text { WHO } \\
\text { Terminology }\end{array}$ & Pangolin * & S Protein Mutations of Interest & $\begin{array}{l}\text { Country of First } \\
\text { Detection }\end{array}$ & $\begin{array}{l}\text { Time of First } \\
\text { Detection }\end{array}$ \\
\hline \multirow{7}{*}{$\sum_{\infty}^{\infty}$} & Epsilon & B.1.427/B.1.429 & L452R, D614G, S13I, W152C, L452R, D614G & $\begin{array}{l}\text { United States } \\
\text { (California) }\end{array}$ & September 2020 \\
\hline & Eta & B.1.525 & $\begin{array}{c}\text { A67V, 69del, 70del, 144del, E484K, D614G, } \\
\text { Q677H, F888L }\end{array}$ & $\begin{array}{c}\text { United } \\
\text { Kingdom/Nigeria }\end{array}$ & December 2020 \\
\hline & Iota & B.1.526 & $\begin{array}{l}\text { L5F, }\left(\mathrm{D} 80 \mathrm{G}^{*}\right), \mathrm{T} 95 \mathrm{I},\left(\mathrm{Y} 144-^{*}\right),\left(\mathrm{F} 157 \mathrm{~S}^{*}\right), \\
\text { D253G, }\left(\mathrm{L}^{2} 52 \mathrm{R}^{*}\right),\left(\mathrm{S} 477 \mathrm{~N}^{*}\right), \mathrm{E} 484 \mathrm{~K}, \mathrm{D} 614 \mathrm{G}, \\
\text { A701V, }\left(\mathrm{T} 859 \mathrm{~N}^{*}\right),\left(\mathrm{D} 950 \mathrm{H}^{*}\right),\left(\mathrm{Q} 957 \mathrm{R}^{*}\right)\end{array}$ & $\begin{array}{l}\text { United States } \\
\text { (New York) }\end{array}$ & November 2020 \\
\hline & Kappa & B.1.617.1 & $\begin{array}{l}\text { (T95I), G142D, E154K, L452R, E484Q, } \\
\text { D614G, P681R, Q1071H }\end{array}$ & India & December 2020 \\
\hline & Zeta & P.2 & E484K, (F565L*), D614G, V1176F & Brazil & April 2020 \\
\hline & Lambda & C.37 & $\begin{array}{c}\text { G75V, T76I, 246-252del, L452Q, F490S, } \\
\text { D614G and T859N }\end{array}$ & Peru & December 2020 \\
\hline & $\mathrm{Mu}$ & B.1.621, B.1.621.1 & $\mathrm{N} / \mathrm{A}$ & Colombia & September 2021 \\
\hline
\end{tabular}


Table 1. Cont.

\begin{tabular}{|c|c|c|c|c|c|}
\hline & $\begin{array}{l}\text { WHO } \\
\text { Terminology }\end{array}$ & Pangolin * & S Protein Mutations of Interest & $\begin{array}{l}\text { Country of First } \\
\text { Detection }\end{array}$ & $\begin{array}{l}\text { Time of First } \\
\text { Detection }\end{array}$ \\
\hline & Alpha & B.1.1.7 & $\begin{array}{l}\text { 69del, 70del, 144del, (E484K*), (S494P*), } \\
\text { N501Y, A570D, D614G, P681H, T716I, } \\
\text { S982A, D1118H (K1191N*) }\end{array}$ & United Kingdom & September 2020 \\
\hline & Beta & B.1.351 & $\begin{array}{l}\text { D80A, D215G, 241del, 242del, 243del, } \\
\text { K417N, E484K, N501Y, D614G, A701V }\end{array}$ & South Africa & May 2020 \\
\hline & Gamma & P.1 & $\begin{array}{l}\text { L18F, T20N, P26S, D138Y, R190S, K417T, } \\
\text { E484K, N501Y, D614G, H655Y, T1027I }\end{array}$ & Japan/Brazil & November 2020 \\
\hline \multirow[t]{2}{*}{$\stackrel{y}{>}$} & Delta & B.1.617.2 & $\begin{array}{l}\text { T19R, (V70F*), T95I, G142D, E156-, F157-, } \\
\text { R158G, (A222V*), (W258L*), (K417N), } \\
\text { L452R, T478K, D614G, P681R, D950N }\end{array}$ & India & October 2020 \\
\hline & Omicron & B.1.1.529 & $\mathrm{N} / \mathrm{A}$ & South Africa & November 2021 \\
\hline
\end{tabular}

\section{Clinical Overview of COVID-19}

As with other coronaviruses, SARS-CoV-2 uses its transmembrane $S$ protein to enter host cells (Figure 2). It binds with high affinity to human Angiotensin Converting Enzyme 2 (ACE2), ACE2 receptors, which acts as a cellular doorway for SARS-CoV-2 to fuse and enter the target cells [20]. Once this connection is established between the virus and the ACE2 receptor, an endosomal cysteine protease, Transmembrane Serine Protease 2 (TMPRSS2), is activated, and the virus enters the host cell via endocytosis [21]. After the virus enters the cell, it hijacks the cell's protein machinery and starts making new virus particles which are released from the host cell and infect neighboring healthy cells, causing COVID-19 infection.

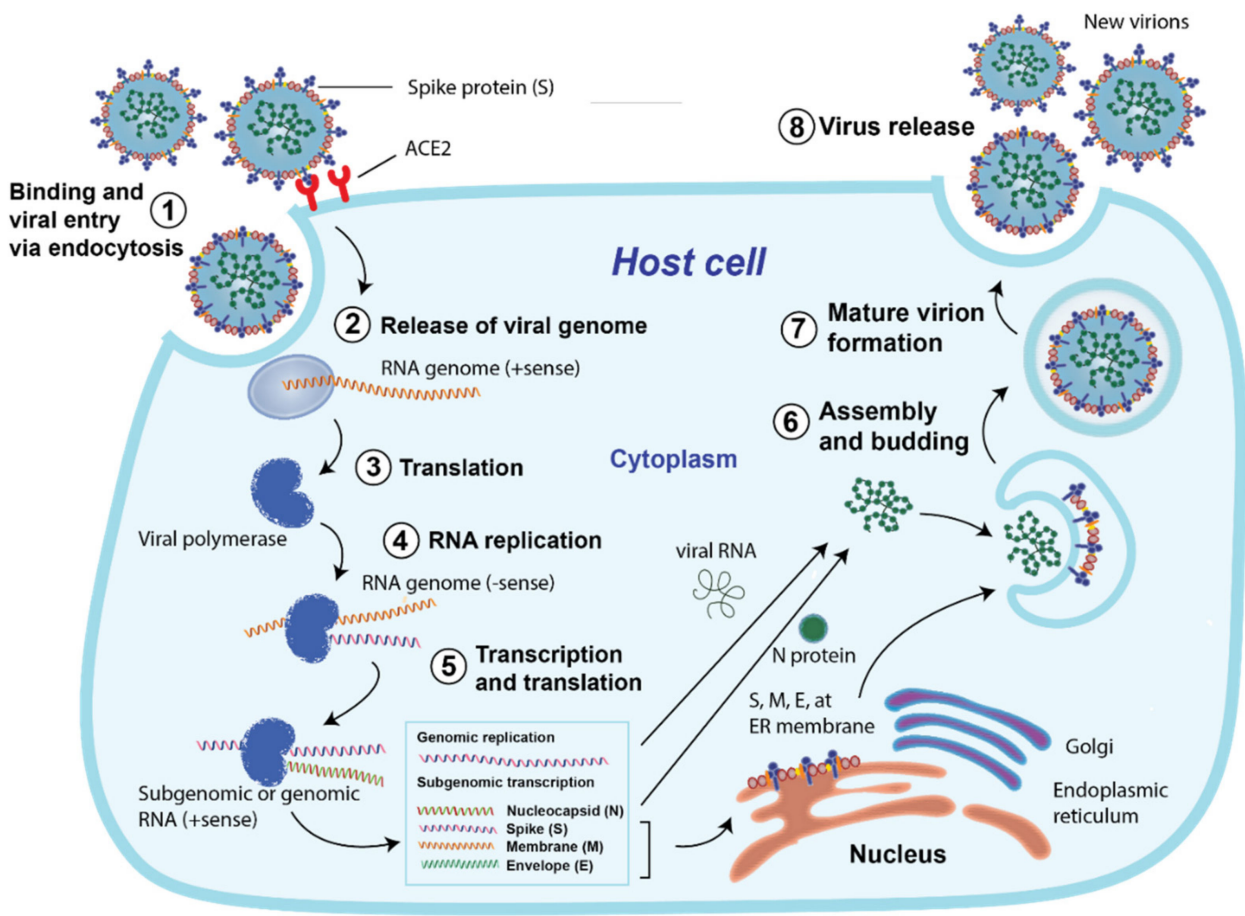

Figure 2. SARS CoV-2 life cycle: (1) Binding and viral entry to the host cell via endocytosis; (2) release of viral genome; (3) translation and (4) replication of RNA genome; (5) transcription and translation of RNA into protein; (6) assembly and budding, followed by (7) mature virion formation; and (8) release of the new virion from the host cell. (Redrawn by the authors based on second figure in Ref. [22]). 
COVID-19 is a highly transmissible disease that represents a severe threat to public health, causing mild or moderate symptoms in most infected individuals; in $\sim 20 \%$ of cases, this can be severe [23]. The virus is primarily transmitted through respiratory droplets (aerosols) from close contact between individuals [24]. The most common method used in the diagnosis of COVID-19 is real-time reverse transcriptase polymerase chain reaction (RT-PCR) of respiratory specimens, including nasal and pharyngeal swab or lung fluids [1]. Common COVID-19 symptoms include cough, shortness of breath, fatigue, fever, and loss of taste and smell, but in some cases it can progress to pneumonia, followed by a critical condition known as acute respiratory distress syndrome (ARDS), which can potentially result in multi-organ failure (MOF) and death [1,25-27]. Frequency of developing severe disease increases with age and comorbidities such as hypertension, obesity, and diabetes [28].

Although COVID-19 infection lasts approximately 2 weeks in most individuals and its acute effects fade by the end of the infection, its long-term effects have been demonstrated in some individuals, mainly health care workers who have had significant exposure to the virus [29]. The most common long-term effect that COVID "Long Haulers" suffer from is dyspnea, observed in $\sim 40 \%$ of individuals [30,31]. Risk of myocardial inflammation is also substantially increased in patients who have recovered from COVID-19 [32,33]. Other residual negative effects from COVID-19 infection include increased fatigue, muscular weakness, chest pain, chronic kidney disease, neuropsychiatric disorders, cognitive disturbances and increased risk of thromboembolism [34].

Some existing small molecule drugs have been tested against COVID-19 clinically. Due to its demonstrated potent in vitro inhibitory activity against $S A R S-C o V$, antimalarial drug, chloroquine, was proposed as an effective treatment against COVID-19 [35]. A much less toxic derivative of chloroquine, hydroxychloroquine, gained wide interest from researchers in the early days of the pandemic; however, several randomized controlled trials and metaanalyses have clearly indicated that hydroxychloroquine and chloroquine are not associated with improved recovery or reduced mortality rates [36,37]. In light of these results, The USA Food and Drug Administration (FDA) revoked the emergency use authorization for hydroxychloroquine and chloroquine on 15 June 2020 [38].

Antiviral, remdesivir, has been effective in shortening the recovery time, decreasing the mortality rate and lowering respiratory tract infections in hospitalized adults with COVID-19 [39], and it is the only currently approved small molecule drug for use by most health regulatory authorities including European Medicines Agency (EMA) and FDA against COVID-19 [40,41]. Dexamethasone, a corticosteroid, has also shown to increase recovery of patients with severe COVID-19; however, the use of corticosteroids is not recommended in people with non-severe COVID-19 because of their potentially serious adverse effects [42]. Other drugs, recommended by The National Institute of Health (NIH) COVID-19 Treatment Guidelines Panel, to be useful depending on the severity of COVID-19, are baricitinib (an anti-inflammatory biologic for rheumatoid arthritis), tocilizumab (an anti-IL-6R monoclonal immunosuppressive antibody used for autoimmune disorders) and neutralizing SARS-CoV-2 combination monoclonal antibodies, bamlanivimab/etesevimab (Eli Lilly), casirivimab/imdevimab (Regeneron Pharmaceuticals) and sotrovimab (GSK/Vir Biotech) [43] for mild to moderate cases, in particular in the early stages of infection.

Clinical trial data released in October by pharmaceutical company Merck demonstrated that molnupiravir, another antiviral, can reduce the risk of hospitalization or death by around 50\% [44]. The UK Medicines and Healthcare Products Regulatory Agency (MHRA) has granted authorization for molnupiravir as the first oral antiviral in treating mild-to-moderate COVID-19 on 4 November 2021 [45].

Pfizer has recently developed an oral small molecule antiviral drug candidate, PF07321332, with coronavirus-specific protease inhibitory activity and the drug has entered clinical trials (ClinicalTrials.gov Identifier: NCT04756531) [46,47]. Clinical trial data published in November 2021 have shown that PAXLOVID ${ }^{\mathrm{TM}}$ (PF-07321332 and ritonavir combination) has been shown to reduce the risk of hospitalization or death by $89 \%$; how- 
ever, as of 29 November 2021, it has not been approved by regulatory authorities yet [48]. Even though the advances in novel drug development are promising, they will not be able to help with the fight to stop the transmission of the virus. COVID-19 has been spreading uncontrollably since the beginning of this pandemic, and the history of infectious diseases has shown that successful vaccines against COVID-19 remain the best weapon.

\section{Traditional Vaccine Discovery}

The beginning of the modern vaccination era is attributed to the English physician Edward Jenner, dating back to 1796, who is considered to have made one of the most significant breakthroughs in public health. Prior to Jenner, however, there was a technique called 'inoculation' or 'engrafting' that was practiced widely in Asia Minor and Far East [49]. Jenner was not the first scientist to determine that individuals who had contracted cowpox did not develop smallpox infection; however, he was the first to demonstrate that using cowpox pus from an infected person, another individual could be immunized, creating the first vaccine [50]. This discovery has led many researchers around the world to focus their research on vaccination, fostering advancements in the immunology field. Smallpox, one of the deadliest infections in human history, was declared eradicated in 1980 by WHO through worldwide vaccination campaigns, and many infectious diseases such as measles, polio, diphtheria and whooping cough, once seen as a significant threat to the community, are not a public health concern anymore in most parts of the world, thanks to the continuous global vaccination efforts for decades [51].

Historically, developing a safe and effective vaccine has required $\sim$ ten years, starting from early preclinical studies and followed by Phase 1-3 human clinical trials and then the arduous authorization process by national and international regulatory bodies [52]. Phase 1 involves determining the efficacy and evaluating the basic safety of the vaccine candidate in a small group (20-200) of healthy individuals [53]. Phase 2 involves a larger sample group with several hundred individuals and aims to collect additional information on safety, immunogenicity, efficacy and appropriate dosing of the vaccine candidate [53]. Phase 3 involves thousands of individuals and assesses the safety and efficacy of the vaccine candidate in larger populations, identifies real-world reactions to the vaccine candidate and determines the effectiveness by comparing vaccinated and unvaccinated groups [53]. If these results collectively demonstrate acceptable safety and efficacy, manufacturers can then submit authorization applications to different regulatory jurisdictions.

\section{Classes of COVID-19 Vaccines}

From the early days of the pandemic, it was clear to vaccine scientists/researchers, public health agencies and political leaders across the globe that the most effective way to fight the pandemic was to develop effective vaccines. Concerted global coordination and collaboration, and injection of significant financial resources from governments as well as philanthropic individuals and institutions (like the Bill \& Melinda Gates Foundation and Wellcome Trust), has led to the first vaccine against COVID-19 being approved for emergency use by MHRA on 2 December 2020 and by FDA on 11 December 2020, less than a year after the pandemic began [54,55]. As of 15 November 2021, 23 vaccines have been authorized or approved for emergency use in at least one country, most receiving Emergency Use Authorization (Table 2 and Appendix A), 122 vaccine candidates are in different phases (1-3) of clinical trials (Appendix B) and 194 vaccine candidates are in pre-clinical development phase [56,57].

COVID-19 vaccines and vaccine candidates may be categorized into four groups based on their development technology. In addition to traditional vaccine development platforms such as inactivated and live attenuated vaccines, novel methods including nucleic acid vaccines and viral vector vaccines are also being used in the development of COVID19 vaccines. The four broad groups of COVID-19 vaccines are summarized in Figure 3 followed by a brief description of these vaccine types. 


\subsection{Whole Virus COVID-19 Vaccines}

\subsubsection{Inactivated Vaccines}

Inactivated vaccines are produced by using heat, radiation or chemicals, such as formaldehyde or $\beta$-propiolactone, to break down the viral structure and/or genetic material [58]. These vaccines still contain all parts of the virus, but in an inactive form making the virus unable to cause human disease. Inactivated vaccines are generally considered safe, easy to develop and manufacture and are less immunogenic; as such, they may not induce a strong enough immune response, which would necessitate addition of adjuvants and/or multiple doses [59].

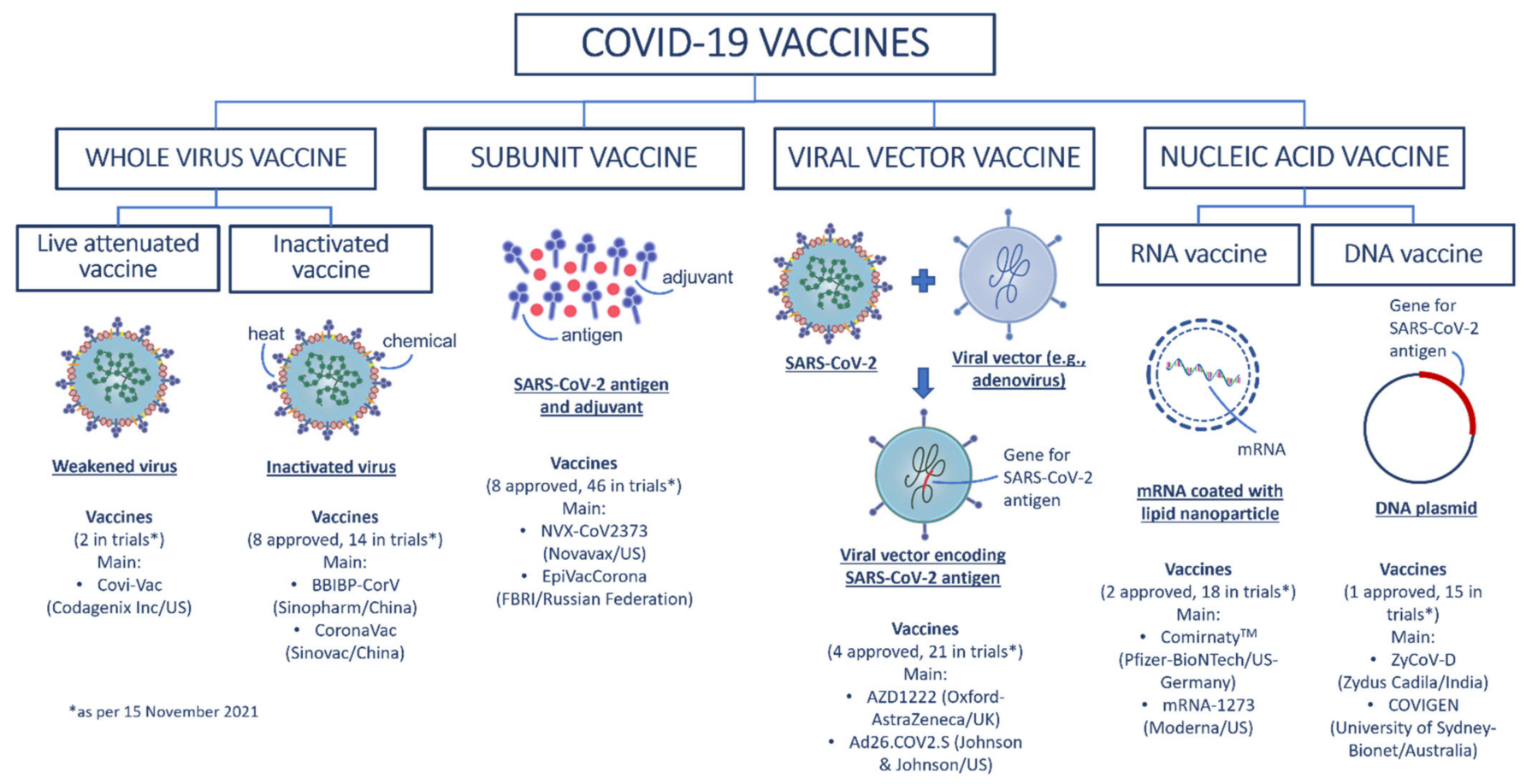

Figure 3. Schematic summary of the four broad groups of COVID-19 vaccines with examples of current COVID-19 vaccines. (Redrawn by the authors based on second figure in Ref. [60]).

Since the start of the COVID-19 pandemic, inactivated vaccine development has been the preferred vaccine development platform by some companies since it is the most established methodology with easy development and manufacturing of vaccines without compromising safety. As of 15 November 2021, there are 17 inactivated COVID-19 vaccines and/or vaccine candidates being tested in different phases of clinical trials. 8 of these 16 vaccines; Sinopharm-BBIBP-CorV (Sinopharm, Beijing, China), CoronaVac (Sinovac, Beijing, China), Covaxin (Bharat Biotech, Hyderabad, India), Sinopharm-WIBP (Sinopharm, Beijing, China), CoviVac (Chumakov Center, Moscow, Russia), QazVac (Research Institute for Biological Safety Problems, Zhambyl, Kazakhstan), COVIran Barakat (Shifa Pharmed Industrial Co, Kordan, Iran) and another vaccine developed by Shenzhen Kangtai Biological Products, China have been granted emergency use authorization in at least one country [57]. However, only three of these vaccines, Sinopharm-BBIBP-CorV, SinopharmWIBP, and CoronaVac, were included in the WHO Emergency Use Listing (EUL) released on 12 November 2021 [61].

Clinical trials of CoronaVac were conducted in more than 10 million individuals from four countries: Chile, Indonesia, Brazil and Turkey. Results from these trials show that the effectiveness of vaccination varies between $50 \%$ and $84 \%$; however, the efficacy of vaccine against hospitalization was superior, $85 \%$ in Chile and $100 \%$ in Brazil and Turkey. Sinopharm-BBIBP-CorV was found to be $78 \%$ effective in phase 3 trials that were conducted in approximately 40,000 participants from the United Arab Emirates and Bahrain [62]. 
According to a survey of 1526 individuals who had CoronaVac, the most common side effect after the vaccination was localized pain at the injection site, which accounted for $\sim 70 \%$ of the total reported side effects, that was experienced by $15 \%$ of the vaccinated group. Other notable side effects were fatigue, muscle pain and dizziness, which were experienced by $8.3 \%, 8.1 \%$ and $6 \%$ of the group, respectively [63]. Of the 35.8 million doses that have been administered since CoronaVac authorization in China by March 2021, the number of severe adverse effects reported was only 49 [64].

\subsubsection{Live Attenuated Vaccines}

Live attenuated virus vaccines are developed by attenuating the viruses, usually by repeated culturing. These vaccines generate a strong immune response and in most attenuated vaccines immunity is produced with a single dose. This strong immune response, however, can cause unwanted effects resulting in limited use of these vaccines in individuals with compromised immune status. This vaccine development method is the least preferred of the existing methods and as of 15 November 2021, only two COVID-19 vaccine candidates, which are in phase 3 and 1 trials, were developed using this method [65].

\subsection{Subunit Vaccines}

Unlike traditional platforms, a subunit vaccine only uses a part of the virus, as antigen, to stimulate immune response. This type of vaccine is developed using recombinant proteins or synthetic peptides targeting specific epitope, therefore eliminating the potential risk of pathogenicity and thus minimizing side-effects [65]. Despite such advantages, the ability of subunit vaccines to trigger immune response are lower than those vaccines that contain the entire virus. Thus, multiple doses and adjuvant(s) are often needed $[66,67]$. Several types of COVID-19 subunit vaccines are being developed: protein subunit vaccines containing specific isolated proteins from virus; polysaccharide vaccines that contain chains of sugar molecules; conjugate subunit vaccines in which a polysaccharide chain is attached to a carrier protein; and virus-like particles (VLPs) which mimic the structure of actual virus particles [68].

The $\mathrm{S}$ protein is used as the pivotal target for developing subunit vaccines against SARS-CoV-2, as it plays a key role in receptor binding and serves as the major antigen that triggers the response of protective neutralizing antibodies [69]. As of 15 November 2021, eight protein subunit vaccines against SARS-CoV-2 have been approved for emergency use at least in one country, such as RBD-Dimer, developed by Anhui Zhifei Longcom Biopharmaceutical, that uses a dimeric form of the S protein RBD. EpiVacCorona, developed by Vektor State Research Center of Virology and Biotechnology in Russia, utilizes a synthetic peptide antigen of SARS-CoV-2 containing a carrier protein and an adjuvant (Table 2).

\subsection{Viral Vector Vaccines}

Viral vectors are viruses that have been genetically engineered to create vaccines. They are completely harmless and are used as carriers to deliver the genetic information which the host cell uses to produce the antigen that initiates the body's immune response [70]. The concept of using a virus as a vector dates back to 1972 [71]; however, it was not until 2019 that the first viral vector vaccine, ERVEBO ${ }^{\circledR}$ vaccine against Ebola virus, was approved for human use [72]. Several viruses such as Retrovirus, Lentivirus, Cytomegalovirus and Adenovirus have been used as carriers. Adenovirus is the most frequently used viral vector due to its well-established safety profile and inflammatory and immune system triggering effects [70].

This vaccine development platform is one of the most common used technologies for the development of COVID-19 vaccines; a number of vaccines developed with this approach are approved for emergency use in several countries and this method will remain a promising vaccine development pathway for ongoing vaccine research [57]. As of 15 November 2021, 21 viral vector vaccines have entered clinical trials and four of these vaccines; ChAdOx1-S (Oxford-AstraZeneca, Cambridge, UK and Stockholm, Sweden), 
Sputnik V (Gamaleya Research Institute, Moscow, Russia), Ad26.COV2.S (Johnson \& Johnson, New Brunswick, NJ, USA) and Convidecia (CanSino Biologics, Shanghai, China) have been approved for either emergency or full use in different countries [65].

ChAdOx1-S by Oxford-AstraZeneca was approved for emergency use against COVID-19 on 30 December 2020 and in the subsequent 6 months it has become the most widely approved COVID-19 vaccine internationally [57]. Clinical trials have demonstrated that the vaccine is $66 \%$ effective after the second dose against COVID-19 infection with no hospital admissions in the vaccinated group [73]. However, it has been associated with venous thromboembolism, coagulation disorders and blood clots. According to a study that examined 280,000 vaccinated individuals, 59 venous thromboembolic events were observed in the vaccinated cohort compared with 30 expected based on the incidence rates in the general population, corresponding to a standardised morbidity ratio of 1.97 . The same study also demonstrated that the standardised morbidity ratio for any thrombocytopenia/coagulation disorders was 1.52, indicating an increased risk of around 50\% [74]. In some cases, these adverse events have led to several deaths, which has prompted nine countries in Europe to suspend emergency use approval of this vaccine [75]. A recent study demonstrated that ChAdOx1 viral vaccine vector binds to platelet factor 4 (PF4), a protein involved in the pathogenesis of heparin-induced thrombocytopenia (HIT), which could be a major step in discovering the mechanism underlying this rare side effect [76].

\subsection{Nucleic Acid COVID-19 Vaccines}

Nucleic acid-based vaccines have received much interest in the field of new vaccines, following studies in the early 1990s that plasmid DNA induces an immune response to the plasmid-encoded antigen and a mRNA vaccine was found to be effective as a result of direct gene transfer $[47,77,78]$.

Nucleic acid vaccines use a part of genetic material in the form of DNA (as plasmids) or RNA (as mRNA) which encode and are translated in cells to a specific protein to stimulate immune responses. They have significant benefits over conventional methods in terms of safety (live virus and adjuvant are not required), effectiveness (expressing antigen in situ and mimicking true infection, thus inducing both B and T-cell responses), and high specificity (inducing immune response to the antigen of interest only) [79]. Additionally, it is relatively cheap and requires a shorter time to develop and manufacture this type of vaccine compared to traditional vaccines.

\subsubsection{DNA Vaccines}

DNA vaccines are formulated in the form of plasmids expressing the specific target protein (antigen). This process requires the intermediary steps of translation of DNA into messenger RNA which carries the specific genetic information (code) to the ribosomes where the protein synthesis takes place [80]. As per 15 November 2021, a DNA vaccine candidate against SARS-CoV-2, ZyCoV-D, has been approved for emergency use in India (Table 2) and several others are being developed and are entering clinical trials (Appendix B), like AG0301-COVID19 (Phase 2/3-AnGes, Tottori, Japan), and Covigenix VAX-001 (Phase 1-Entos Pharmaceuticals Inc, Edmonton, AB, Canada).

\subsubsection{RNA Vaccines}

RNA vaccine in the form of mRNA involves an intermediate process between DNA and protein translation by ribosomes. Currently, there are two main types of mRNA vaccines being studied: non-replicating mRNA, and self-amplifying RNA. The conventional non-replicating mRNA containing $5^{\prime}$ and $3^{\prime}$ untranslated region (UTRs) work by encoding the protein of interest, whereas the self-amplifying RNA encodes not only the protein/antigen, but also the viral replication machinery enabling the intracellular RNA amplification and large amounts of protein expression [81].

Although they work in similar manner, RNA-based vaccines appear to be more effective and safer than DNA vaccines; injection of RNA poses no (or minimal) risk of 
disrupting original DNA sequences in cells since it does not need to enter the cell nucleus [82]. The mRNA vaccines have become one of the leading vaccines to be developed against SARS-CoV-2. Two mRNA vaccines: BNT162b2 (Pfizer/BioNTech, New York, NY, USA/Berlin, Germany) and mRNA-1273 (Moderna, Cambridge, MA, USA) have been approved for emergency use worldwide (Table 2). Recently, BNT162b2 (Pfizer/BioNTech, New York, NY, USA/Berlin, Germany) vaccine received full approval from the FDA.

Table 2. Authorized/approved vaccines in at least one country as per 15 November 2021.

\begin{tabular}{|c|c|c|c|c|c|c|c|c|c|}
\hline No & $\begin{array}{l}\text { Vaccine } \\
\text { Name }\end{array}$ & Status & Developer & $\begin{array}{l}\text { Vaccine } \\
\text { Type }\end{array}$ & Efficacy & Dose & Storage & Price (per Dose) & Source \\
\hline 1 & $\begin{array}{l}\text { Comirnaty } \\
\text { (BNT162b2) }\end{array}$ & $\begin{array}{c}\text { Approved in } \\
\text { several countries, } \\
\text { emergency use in } \\
\text { US, elsewhere }\end{array}$ & $\begin{array}{l}\text { Pfizer-BioNTech } \\
\text { Germany-US }\end{array}$ & $\begin{array}{l}\text { RNA based } \\
\text { vaccine }\end{array}$ & $95 \%[83]$ & $\begin{array}{c}2 \text { dose, } 3 \text { weeks } \\
\text { apart [84] }\end{array}$ & $-70{ }^{\circ} \mathrm{C}[85]$ & $\begin{array}{c}€ 19.50 \\
\text { (US\$23.15) [86] }\end{array}$ & [56] \\
\hline 2 & $\begin{array}{c}\text { Moderna } \\
\text { mRNA-1273 } \\
\text { and mRNA- } \\
1273.351\end{array}$ & $\begin{array}{l}\text { Approved in } \\
\text { Switzerland, } \\
\text { emergency use in } \\
\text { US, elsewhere }\end{array}$ & $\begin{array}{c}\text { ModernaTX, Inc } \\
\text { US }\end{array}$ & $\begin{array}{l}\text { RNA based } \\
\text { vaccine }\end{array}$ & $94.1 \%[87]$ & $\begin{array}{l}2 \text { doses, } \\
4 \text { weeks } \\
\text { apart [88] }\end{array}$ & $-25^{\circ} \mathrm{C}[89]$ & US\$25.50 [86] & {$[56]$} \\
\hline 3 & $\begin{array}{l}\text { AstraZeneca } \\
\text { AZD1222 }\end{array}$ & $\begin{array}{l}\text { Approved in } \\
\text { Brazil, emergency } \\
\text { use in EU, } \\
\text { elsewhere }\end{array}$ & $\begin{array}{c}\text { The University of } \\
\text { Oxford- } \\
\text { AstraZeneca } \\
\text { UK }\end{array}$ & $\begin{array}{l}\text { Viral vector } \\
\text { (non- } \\
\text { replicating) }\end{array}$ & $76 \%[90]$ & $\begin{array}{c}2 \text { doses, } \\
\text { between four } \\
\text { and } 12 \text { weeks } \\
\text { apart [91] }\end{array}$ & $2-8{ }^{\circ} \mathrm{C}[85]$ & $\begin{array}{c}\text { US\$2.15 (EU), } \\
\text { US\$5.25 } \\
\text { (others) [92] }\end{array}$ & [56] \\
\hline 4 & $\begin{array}{l}\text { Convidecia } \\
\text { (Ad5-nCoV) }\end{array}$ & $\begin{array}{l}\text { Approved in } \\
\text { China, emergency } \\
\text { use in other } \\
\text { countries }\end{array}$ & $\begin{array}{l}\text { CanSino } \\
\text { Biologics } \\
\text { China }\end{array}$ & $\begin{array}{l}\text { Viral vector } \\
\text { (non- } \\
\text { replicating) }\end{array}$ & $65.28 \%$ & Single dose & $2-8{ }^{\circ} \mathrm{C}[93]$ & $\begin{array}{c}\text { US\$27.15 } \\
\text { (Pakistan) [94] }\end{array}$ & [56] \\
\hline 5 & Ad26.COV2.S & $\begin{array}{l}\text { Emergency use in } \\
\text { US, elsewhere }\end{array}$ & $\begin{array}{l}\text { Janssen (Johnson } \\
\text { \& Johnson) US }\end{array}$ & $\begin{array}{l}\text { Viral vector } \\
\text { (non- } \\
\text { replicating) }\end{array}$ & $66.9 \%[95]$ & $\begin{array}{c}\text { Single } \\
\text { dose [95] }\end{array}$ & $2-8{ }^{\circ} \mathrm{C}[85]$ & US\$10 [96] & [56] \\
\hline 6 & BBIBP-CorV & $\begin{array}{l}\text { Approved in } \\
\text { China, Bahrain, } \\
\text { UAE, emergency } \\
\text { use in other } \\
\text { countries }\end{array}$ & $\begin{array}{l}\text { Sinopharm } \\
\text { (Beijing) } \\
\text { China }\end{array}$ & $\begin{array}{l}\text { Inactivated } \\
\text { virus }\end{array}$ & $79 \%[97]$ & $\begin{array}{c}2 \text { doses, } \\
3 \text { weeks } \\
\text { apart [98] }\end{array}$ & $2-8{ }^{\circ} \mathrm{C}[99]$ & $\begin{array}{c}\text { US\$37.50 } \\
\text { (Hungary) [100] }\end{array}$ & [56] \\
\hline 7 & $\begin{array}{l}\text { Inactivated } \\
\text { SARS-CoV-2 } \\
\text { (vero cell) }\end{array}$ & $\begin{array}{l}\text { Approved in } \\
\text { China, Limited } \\
\text { use in UAE }\end{array}$ & $\begin{array}{c}\text { Sinopharn }+ \\
\text { Wuhan Institute } \\
\text { of Biological } \\
\text { Products } \\
\text { China }\end{array}$ & $\begin{array}{l}\text { Inactivated } \\
\text { virus }\end{array}$ & $72.8 \%$ & $\begin{array}{c}2 \text { doses, } \\
3 \text { weeks apart }\end{array}$ & $2-8{ }^{\circ} \mathrm{C}$ & $\mathrm{N} / \mathrm{A}$ & {$[56]$} \\
\hline 8 & CoronaVac & $\begin{array}{c}\text { Approved in } \\
\text { China, emergency } \\
\text { use in other } \\
\text { countries }\end{array}$ & $\begin{array}{l}\text { Sinovac } \\
\text { China }\end{array}$ & $\begin{array}{l}\text { Inactivated } \\
\text { virus }\end{array}$ & $\begin{array}{c}51 \% \text { in Brazil } \\
\text { trial, } 84 \% \text { in } \\
\text { Turkey } \\
\text { trial }[99]\end{array}$ & $\begin{array}{l}2 \text { doses, } \\
2 \text { weeks } \\
\text { apart [99] }\end{array}$ & $2-8{ }^{\circ} \mathrm{C}[89]$ & $\begin{array}{l}\text { US\$13.60 (In- } \\
\text { donesia) [101] }\end{array}$ & {$[56]$} \\
\hline 9 & Sputnik V & $\begin{array}{l}\text { Emergency use in } \\
\text { Russia, elsewhere }\end{array}$ & $\begin{array}{l}\text { The Gamaleya } \\
\text { Research } \\
\text { Institute } \\
\text { Russia }\end{array}$ & $\begin{array}{l}\text { Viral vector } \\
\text { (non- } \\
\text { replicating) }\end{array}$ & $91.6 \%$ & $\begin{array}{c}2 \text { doses, } \\
3 \text { weeks apart }\end{array}$ & $-18^{\circ} \mathrm{C}[89]$ & $\begin{array}{l}\text { Less than } \\
\text { US\$10 [102] }\end{array}$ & [103] \\
\hline 10 & EpiVacCorona & $\begin{array}{c}\text { Approved in } \\
\text { Turkmenistan, } \\
\text { early use in Russia }\end{array}$ & $\begin{array}{l}\text { FBRI } \\
\text { Russia }\end{array}$ & $\begin{array}{l}\text { Protein } \\
\text { subunit }\end{array}$ & N/A & $\begin{array}{c}2 \text { doses, } \\
3 \text { weeks apart }\end{array}$ & $2-8{ }^{\circ} \mathrm{C}$ & US\$11 [104] & [103] \\
\hline 11 & $\begin{array}{l}\text { ZF2001/RBD- } \\
\text { Dimer }\end{array}$ & $\begin{array}{l}\text { Emergency use in } \\
\text { China, Uzbekistan }\end{array}$ & $\begin{array}{l}\text { Anhui Zhifei } \\
\text { Longcom } \\
\text { China }\end{array}$ & $\begin{array}{l}\text { Protein } \\
\text { subunit }\end{array}$ & N/A & $\begin{array}{c}3 \text { doses, } \\
4 \text { weeks apart }\end{array}$ & $2-8{ }^{\circ} \mathrm{C}$ & N/A & [103] \\
\hline 12 & $\begin{array}{l}\text { Soberana } \\
\text { 2/Pasteur }\end{array}$ & $\begin{array}{l}\text { Emergency use in } \\
\text { Iran, Cuba }\end{array}$ & $\begin{array}{c}\text { Instituto Finlay } \\
\text { de Vacunas } \\
\text { Cuba }\end{array}$ & $\begin{array}{l}\text { Protein } \\
\text { subunit }\end{array}$ & $\begin{array}{c}62 \% \text { two } \\
\text { doses, } 91.2 \% \\
\text { with } \\
\text { Soberana } \\
\text { Plus }\end{array}$ & $\begin{array}{c}2 \text { doses, } \\
4 \text { weeks apart }\end{array}$ & $2-8{ }^{\circ} \mathrm{C}$ & $\mathrm{N} / \mathrm{A}$ & [103] \\
\hline 13 & $\begin{array}{l}\text { Abdala/CIGB- } \\
\quad 66\end{array}$ & $\begin{array}{c}\text { Emergency use in } \\
\text { Cuba }\end{array}$ & $\begin{array}{c}\text { Center for } \\
\text { Genetic } \\
\text { Engineering and } \\
\text { Biotechnology } \\
\text { (CIGB) } \\
\text { Cuba }\end{array}$ & $\begin{array}{l}\text { Protein } \\
\text { subunit }\end{array}$ & $92.28 \%$ & $\begin{array}{c}3 \text { doses, } \\
2 \text { weeks apart }\end{array}$ & $2-8^{\circ} \mathrm{C}$ & $\mathrm{N} / \mathrm{A}$ & [103] \\
\hline 14 & Medigen & $\begin{array}{c}\text { Emergency use in } \\
\text { Taiwan }\end{array}$ & $\begin{array}{c}\text { Medigen Vaccine } \\
\text { Biologics } \\
\text { Taiwan }\end{array}$ & $\begin{array}{l}\text { Protein } \\
\text { subunit }\end{array}$ & N/A & $\begin{array}{c}2 \text { doses, } \\
4 \text { weeks apart }\end{array}$ & $2-8{ }^{\circ} \mathrm{C}$ & $\mathrm{N} / \mathrm{A}$ & {$[56]$} \\
\hline 15 & Covaxin $^{\circledR}$ & $\begin{array}{l}\text { Emergency use in } \\
\text { India, elsewhere }\end{array}$ & $\begin{array}{l}\text { Bharat Biotech } \\
\text { India }\end{array}$ & $\begin{array}{l}\text { Inactivated } \\
\text { virus }\end{array}$ & $77.8 \%$ & $\begin{array}{c}2 \text { doses, } \\
4 \text { weeks apart }\end{array}$ & $\begin{array}{l}\text { At least a week } \\
\text { at room } \\
\text { temperature }\end{array}$ & $\begin{array}{c}\text { US\$16.42 } \\
\text { (India) [105] }\end{array}$ & [103] \\
\hline
\end{tabular}


Table 2. Cont.

\begin{tabular}{|c|c|c|c|c|c|c|c|c|c|}
\hline No & $\begin{array}{l}\text { Vaccine } \\
\text { Name }\end{array}$ & Status & Developer & $\begin{array}{l}\text { Vaccine } \\
\text { Type }\end{array}$ & Efficacy & Dose & Storage & Price (per Dose) & Source \\
\hline 16 & $\begin{array}{l}\text { QazCovid- } \\
\text { in }^{\circledR}\end{array}$ & $\begin{array}{l}\text { Early use in } \\
\text { Kazakhstan }\end{array}$ & $\begin{array}{c}\text { Research } \\
\text { Institute for } \\
\text { Biological Safety } \\
\text { Problems } \\
\text { Kazakhstan }\end{array}$ & $\begin{array}{l}\text { Inactivated } \\
\text { virus }\end{array}$ & $\mathrm{N} / \mathrm{A}$ & $\begin{array}{c}1 \text { or } 2 \text { doses, } \\
3 \text { weeks apart }\end{array}$ & $2-8^{\circ} \mathrm{C}$ & US\$4.7 [106] & [103] \\
\hline 17 & $\begin{array}{l}\text { Inactivated } \\
\text { (Vero Cells) }\end{array}$ & $\begin{array}{l}\text { Emergency use in } \\
\text { China }\end{array}$ & $\begin{array}{c}\text { Shenzhen } \\
\text { Kangtai } \\
\text { Biological } \\
\text { Products Co., Ltd. } \\
\text { China }\end{array}$ & $\begin{array}{l}\text { Inactivated } \\
\text { virus }\end{array}$ & $\mathrm{N} / \mathrm{A}$ & $\begin{array}{c}2 \text { doses, } \\
4 \text { weeks apart }\end{array}$ & $2-8^{\circ} \mathrm{C}$ & $\mathrm{N} / \mathrm{A}$ & [103] \\
\hline 18 & $\begin{array}{l}\text { COVIran } \\
\text { Barekat }\end{array}$ & $\begin{array}{l}\text { Emergency use in } \\
\text { Iran }\end{array}$ & $\begin{array}{l}\text { Shifa Pharmed } \\
\text { ParsIran }\end{array}$ & $\begin{array}{l}\text { Inactivated } \\
\text { virus }\end{array}$ & $\mathrm{N} / \mathrm{A}$ & 2 doses & $2-8^{\circ} \mathrm{C}$ & $\mathrm{N} / \mathrm{A}$ & [103] \\
\hline 19 & CoviVac & Early use in Russia & $\begin{array}{c}\text { Chumakov Cente } \\
\text { Russia }\end{array}$ & $\begin{array}{l}\text { Inactivated } \\
\text { virus }\end{array}$ & $\mathrm{N} / \mathrm{A}$ & $\mathrm{N} / \mathrm{A}$ & $2-8^{\circ} \mathrm{C}$ & $\mathrm{N} / \mathrm{A}$ & [103] \\
\hline 20 & $\begin{array}{l}\text { NVX- } \\
\text { CoV2373 }\end{array}$ & $\begin{array}{l}\text { Emergency use in } \\
\text { Indonesia }\end{array}$ & Novavax US & $\begin{array}{l}\text { Protein } \\
\text { subunit }\end{array}$ & $89.7 \%$ & $\begin{array}{c}2 \text { doses, } \\
3 \text { weeks apart }\end{array}$ & $2-8{ }^{\circ} \mathrm{C}$ & $\begin{array}{c}\text { US\$20.90 } \\
\text { (Denmark) [86] }\end{array}$ & [103] \\
\hline 21 & ZyCoV-D & $\begin{array}{l}\text { Emergency use in } \\
\text { India }\end{array}$ & $\begin{array}{c}\text { Zydus } \\
\text { CadilaIndia }\end{array}$ & $\begin{array}{l}\text { DNA based } \\
\text { vaccine }\end{array}$ & $66.6 \%$ & $\begin{array}{c}3 \text { doses, } \\
4 \text { weeks apart }\end{array}$ & $2-8^{\circ} \mathrm{C}$ & $\mathrm{N} / \mathrm{A}$ & [103] \\
\hline 22 & COVAX-19 ${ }^{\circledR}$ & $\begin{array}{l}\text { Emergency use in } \\
\text { Iran }\end{array}$ & $\begin{array}{c}\text { Vaxine } \\
\text { Pty.Ltd/Cinnagen } \\
\text { Co. } \\
\text { Australia }\end{array}$ & $\begin{array}{l}\text { Protein } \\
\text { Subunit }\end{array}$ & $\mathrm{N} / \mathrm{A}$ & $\begin{array}{c}2 \text { doses, } \\
3 \text { weeks apart }\end{array}$ & $\mathrm{N} / \mathrm{A}$ & $\mathrm{N} / \mathrm{A}$ & [103] \\
\hline 23 & $\begin{array}{l}\text { Soberana } \\
\text { Plus }\end{array}$ & $\begin{array}{c}\text { Emergency use in } \\
\text { Cuba }\end{array}$ & $\begin{array}{c}\text { Instituto Finlay } \\
\text { de Vacunas } \\
\text { Cuba }\end{array}$ & $\begin{array}{l}\text { Protein } \\
\text { subunit }\end{array}$ & $\mathrm{N} / \mathrm{A}$ & $\mathrm{N} / \mathrm{A}$ & $\mathrm{N} / \mathrm{A}$ & $\mathrm{N} / \mathrm{A}$ & [103] \\
\hline
\end{tabular}

\section{COVID-19 Vaccines-Future Outlook}

\subsection{Combination COVID-19 Vaccines}

When faced with evolving safety issues and variable supply and logistical challenges with current COVID-19 vaccines, combination COVID-19 vaccinations have emerged as superior alternatives for providing individuals with the immune protection required. A tresearch study carried out in March 2021 revealed that combining several distinct COVID-19 vaccines increased immune responses in mice [107]. Consecutive immunization with an adenovirus vector vaccine followed by inactivated/recombinant subunit/mRNA vaccine particularly enhanced neutralizing antibody levels and promoted antibody response to primary neutralizing antibodies. Preliminary results of the CombiVacS trial, which included over 600 patients in Spain, are the first to demonstrate the benefits of mixing different coronavirus vaccines [108]. Other studies also support this concept in that combining the Oxford-AstraZeneca vaccine and the Pfizer-BioNTech vaccine induces a stronger immune response compared to two doses of the same vaccine [109-111]. However, while no serious side effects have been recorded in mix-and-match trials, some safety concerns remain when combining two distinct vaccines, as each vaccine has its own set of adverse events/side effects.

\subsection{Booster COVID-19 Vaccines}

SARS-CoV-2 B.1.617.2 variant, also known as the Delta variant, was first detected in India in late 2020; quickly spreading to many countries and becoming the dominant variant by mid-2021. Due to its higher transmissibility, this new strain caused a resurgence in the number of COVID-19 cases, particularly in regions with lower vaccination rates [112,113]. Although existing vaccines like BNT162b2 and ChAdOx1 are effective against this new Delta variant, $88 \%$ and $67 \%$ respectively, the efficacy of BNT162B2 was reduced from $94 \%$ to $88 \%$ and from $74 \%$ to $67 \%$ for ChAdOx1 compared to their respective effectiveness against the earlier alpha variant [114]. Breakthrough infections caused by the Delta variant among vaccinated healthcare workers have also been reported in several countries $[115,116]$. The resurgence in COVID-19 cases and the possibility of reductions in the protective effects of the vaccines over time [117], combined with the Delta variant's higher transmissibility and 
increased risk of infection among vaccinated individuals have prompted health authorities to consider introducing booster vaccines.

Recent studies demonstrated that BNT162b2 booster shot significantly reduces the risk of COVID-19 infection and severe illness [118]. Another study tested seven different vaccines (BNT162b2, ChAdOx1-S, mRNA-1273, NVX-CoV2373, Ad26.COV2.S, CVnCoV and VLA2001) as boosters and showed that all seven of them boosted the immunity in both older and younger populations [119]. A number of countries, such as Israel, UAE, Russia and Turkey, had already commenced administering booster shots to high-risk individuals and healthcare professionals, even before the data were published, with an effort to counteract the decrease in immunity over time by standard 2-dose vaccination [120-122]. FDA released a statement on 12 August 2021, authorizing booster vaccines for immunocompromised individuals [123]. Both FDA and EMA have recently approved the use of BNT126b2 and mRNA-1273 as booster vaccines, and as of November 2021, many countries from all the continents around the world are offering their citizens booster shots [120]. $\mathrm{WHO}$ on the other hand, is questioning the urgency for booster doses with concerns that such practice would further increase disparities in vaccination rates in many low income countries, and preventing the ultimate international public health goal of high vaccination rates globally [124].

\subsection{Mandatory COVID-19 Vaccinations}

Another strategy being implemented by several countries and organizations to reduce the spread of COVID-19 is the mandatory vaccination of individuals working in certain sectors such as healthcare, transportation, education and retail. Tajikistan has become the first country to make the COVID-19 vaccines mandatory for all its citizens over 18 years of age [125]. Turkmenistan has been reluctant to share data on COVID-19 cases and deaths since the first days of the pandemic; however, it became the second country to make COVID-19 vaccines mandatory for all its citizens over 18 years of age [126]. Saudi Arabia has imposed mandatory vaccination for all individuals wanting to enter any government or private facility and made full vaccination mandatory for participation in Hajj [127]. Italy, France, Greece and the UK are making it mandatory for certain healthcare workers to be fully vaccinated and are imposing vaccination requirements for many social gatherings and venues including cinemas, bars, clubs and other closed spaces [128]. In the United States, California and New York are the only two states so far to impose a vaccine mandate, requiring all government officials to get fully vaccinated [129]. While these measures have resulted in noticeable increases in vaccination rates, they have also sparked protests around the world, mostly by anti-vaccination activists [130].

\section{COVID-19 Vaccination Consideration}

\subsection{Uniform Vaccine Availability and Affordability}

The development, testing and approval of several vaccines in the space of 18 months is an extraordinary scientific achievement and will be remembered as a milestone in the history of pandemics. Within 8 months, nearly 5 billion doses of vaccines have been administered since the authorization of the first vaccine [3]. Although this number is impressive for such a short time-period, it is not an accurate indicator of the global availability of vaccines. The increased movement of individuals globally, the economic and social interdependencies between countries and the ease of travel will make it even harder to contain the spread of the virus unless the global immunity goal is achieved. To reach the global immunization goal, a huge stepwise increase in the number of vaccines is required, in every region, state and country, particularly in areas with low vaccination rates.

COVID-19 Vaccines Global Access (COVAX) is a worldwide initiative co-led by Gavi the Vaccine Alliance, Coalition for Epidemic Preparedness Innovations (CEPI) and WHO, with UNICEF as the delivery partner; COVAX aims to accelerate the development, manufacturing of COVID-19 vaccines and ensure equitable access for every country in the world [131]. High Income Countries such as UAE, Qatar and Israel have been able to 
vaccinate more than $70 \%$ of their population; however, this target declines to below $1 \%$ in Low- and Middle-Income Countries such as DR Congo, South Sudan and Yemen [3]. One of the goals of COVAX is to ensure that at least $20 \%$ of each country's population receives vaccines. As of 24 August 2021, COVAX has delivered 215 million COVID-19 vaccines to nearly 100 countries with the aim of providing 1.9 billion doses by the end of 2021 [132,133].

The currently available COVID-19 vaccines cost in the order of US\$2 to US\$37 per dose (Table 2). Many western countries (like the US, UK and Australia) either offer these vaccines free of charge to their citizens or subsidize such vaccination programs for the public good. Government or third-party payer subsidized vaccination schemes are designed to absorb the cost of COVID-19 vaccines and to encourage greater participation in COVID-19 vaccinations. According to WHO's report released in April 2021, more than 87\% of the of the vaccine doses have gone to either high income or upper-middle income countries [134]. This issue needs to be addressed. From an ethical perspective, regardless of their wealth or economic situation every individual's access to appropriate basic health care needs to be guaranteed, especially from the perspective of infectious diseases during a global pandemic, since at least a certain percentage of each population needs to be vaccinated to confer herd immunity and to combat a pandemic. In addition, western and other high-income countries have much higher drug budgets and are also able to move funds quickly to COVID-19related activities (testing, vaccine administration programs and/or providing/expanding ICU facilities) as the pandemic evolves. This is neither possible or feasible in many lowand middle- income countries where unfortunately drug/health budgets are smaller and government subsidies or third-party insurers do not operate in the health market. It is therefore critical for world agencies (like WHO, COVAX and the UN) to find equitable solutions to not only timely availability of COVID-19 vaccines for all countries but also at an affordable price so that herd immunity to COVID-19 is reached in all countries. This is especially critical as new variants of the virus emerge which will require additional vaccines beyond the initial vaccination cycle.

\subsection{Vaccine Hesitancy}

The Strategic Advisory Group of Experts on Immunization (SAGE) is a working group whose mission is to advise WHO on global policies and strategies concerning all vaccine-preventable diseases and SAGE defines vaccine hesitancy as "delay in acceptance or refusal of vaccination despite availability of vaccination services" [135]. SAGE was established in 1999; however, emergence of vaccine hesitancy and anti-vaccine (anti-vax) movement(s) can be traced to Jenner's time (18th century), with respect to early smallpox vaccination programs. Factors including religious bigotry (injecting a purulent matter from a lower species to humans), substandard methods used in vaccination and the 1853 Compulsory Vaccination Act being seen as an example of class legislation-initiated public mistrust against vaccination have all given rise to anti-vaccine campaigns [136].

Reluctance to vaccination, in particular essential childhood vaccines like measles, has been rising in recent years [137]. Genuine public discourse about vaccine efficacy and side effects and other safety issues has translated to rising levels of global vaccine hesitancy. Safety of vaccines and vaccination programs have become paramount public health issues that need to be addressed urgently. Major public concerns have arisen for political, religious, socio-economic or philosophic reasons and include, for example, questions about use of cell cultures from human or animal embryo, which are used commonly to grow the virus for vaccine preparation $[138,139]$. It is worth emphasizing that vaccines undergo rigorous safety and efficacy evaluation and their benefits far outweigh their risks as part of mass vaccination programs. Some infections like measles require high levels of herd immunity to prevent community spread. Achieving such herd immunity is a prerequisite to protecting immune-compromised individuals or others who cannot be vaccinated. Inadequate herd immunity is probably the major reason why recent measle outbreaks have been observed in some tight-knit communities in the US, such as Ultra-orthodox Jewish populations in New York and other US states [140]. 
The anti-vaccine movement gained significant momentum in the 1990s due mainly to publications that appeared in Lancet that was retracted $\sim 12$ years later. Andrew Wakefield, a UK physician reported that measles, mumps and rubella (MMR) vaccine caused autism in eight children [141]. Even though this was hypothesized in a small number of children, Wakefield's claims attracted widespread interest, first in the UK but then globally, and resulted in parents either refusing or delaying MMR vaccines and sometimes even other vaccines as well. An upsurge in measles in the UK, EU and particularly in the USA coincided with Wakefield's erroneous claims. Large-scale studies subsequently refuted Wakefield's claims and proved that vaccines were not causing autism [142].

With the proliferation of social media and its rapid and immediate influence, and with the involvement of public figures (e.g., prominent politicians and Hollywood actors), the anti-vax movement has gained an even stronger hold in some regions of the world and has garnered new followers or at least empowered many to be highly skeptical about vaccine safety [143-145]. Currently, there are many online anti-vax campaigns, podcasts, blogs, videos, articles and books [146]. Some "anti-vaxxers" are highly 'educated' in non-medical topics and claim that they would like to protect their children from vaccine side-effects. It is unfortunate, from a public health perspective, that many individuals remain skeptical about the effectiveness and safety of vaccines. A more sophisticated education and behaviorchange approach is necessary to educate the public about overall vaccine development, how vaccines work, nature of vaccine clinical trials and their public health utility as well as their shortcomings, so individuals can base their decisions regarding vaccination on objective scientific evidence and clear public health messages. The potential harmful effects of vaccine hesitancy on global public health has become so evident that the WHO has listed vaccine hesitancy as one of the top ten threats to global health in 2019 [147].

As a result, immunization of many politicians and other prominent public figures with COVID-19 vaccines has been highly publicized to highlight their overall safety and to ensure greater COVID-19 vaccine uptake. Based on surveys that were conducted in 2020, the acceptance rates of COVID-19 vaccines differ dramatically across countries around the world with the highest rate seen in Ecuador (97\%) [148] and the lowest rate in Kuwait $(23 \%)$ [149]. In a study in healthcare workers, the highest COVID-19 vaccine acceptance rate $(94 \%)$ was in those working in COVID-19 departments compared to $77 \%$ in healthcare professionals working in non-COVID-19 departments [150]. A systematic review [151] has shown that the population intending to get a vaccine has declined as the pandemic has progressed, which is likely to be attributed to both increased exposure to misinformation and concerns over the safety of the vaccines [152,153]. The same study demonstrated that generally being female, younger, of lower income or education status or belonging to an ethnic minority group were associated with increased vaccine reluctance. A systematic review of COVID-19 vaccine hesitancy in the US population has shown a similar result with the highest hesitancy rate being in Black/African Americans and pregnant or breastfeeding women [154]. In the case of COVID-19 vaccines, public health authorities not only have to deal with existing prejudices of anti-vaxxers such as political, religious or cultural beliefs, they also need to convince the public that, with advanced vaccine development technologies and the substantial funding that have been provided to the scientific community, it is now possible to develop safe and effective COVID-19 vaccines in much shorter timeframes without compromising effectiveness and more importantly safety.

\section{Conclusions}

Despite stepwise technological advancements in public health and medicine, substantial increases in number of well-trained health personnel, facilities and sophisticated medical equipment and increased access to and sharing of up-to-date scientific and medical information in many countries, the COVID-19 pandemic has proven that pandemic preparedness is still a major global issue that needs to be addressed urgently. SARS, MERS, Ebola, and various influenza outbreaks were able to be contained before evolving into global pandemics; however, it is clear from the ongoing COVID-19 pandemic that the world 
needs to revisit its emergency plans and improve its preparedness for potential similar future outbreaks.

One striking shining light during this pandemic has been the timely development and commercial availability of COVID-19 vaccines. This has largely been possible due to targeted international collaborative research and scientific efforts and availability of significant financial resources from governments, individuals, institutions/international organizations and philanthropists. Although developing COVID-19 vaccines in less than a year has been one of the significant breakthroughs in the history of medical science, with the emergence of new COVID-19 variants, future research needs to specifically focus on vaccines that have the potential to act against new variants to either stop transmission or infection.

Nevertheless, many major issues remain, including uneven availability/distribution of such vaccines across the globe, their affordability and the increase in vaccine hesitancy. These issues will require strong political will and leadership and concerted public health initiatives and messaging if the full potential of COVID-19 vaccines is to be realised for all individuals in all countries irrespective of socio-economic status and cultural and/or religious backgrounds. This is the challenge that lies ahead.

Author Contributions: B.E., R.F.N., I.R., and V.K. contributed to writing, editing, and formatting the manuscript. V.K. supervised the study. All authors have read and agreed to the published version of the manuscript.

Funding: This research received no external funding.

Institutional Review Board Statement: Not applicable.

Informed Consent Statement: Not applicable.

Data Availability Statement: Not applicable.

Acknowledgments: R.F.N. acknowledges the Indonesia Endowment Fund for Education (LPDP) for the postgraduate scholarship.

Conflicts of Interest: The authors declare no conflict of interest. 


\section{Appendix A}

Table A1. More information on authorized/approved vaccines in at least one country as per 15 November 2021.

\begin{tabular}{|c|c|c|c|c|}
\hline No & Vaccine Name & Age Group & Common Side Effect(s) & Main User-Country \\
\hline 1 & Comirnaty $^{\mathrm{TM}}$ (BNT162b2) & 5 years of age and older [84] & $\begin{array}{l}\text { Pain at the injection site, tiredness, headache, muscle } \\
\text { pain, chills, joint pain, and fever }\end{array}$ & $\begin{array}{c}\text { US, UK, South Korea, Singapore, Saudi Arabia, } \\
\text { New Zealand, Japan, Israel, Hungary, Germany, } \\
\text { France, Canada, Australia }\end{array}$ \\
\hline 2 & $\begin{array}{l}\text { Moderna COVID-19 } \\
\text { VaccinemRNA-1273 and } \\
\text { mRNA-1273.351 }\end{array}$ & 18 years of age and older [88] & $\begin{array}{l}\text { Pain at the injection site, tiredness, headache, muscle } \\
\text { pain, chills, joint pain, swollen lymph nodes in the same } \\
\text { arm as the injection, nausea and vomiting, and fever }\end{array}$ & US, UK, Singapore, France \\
\hline 3 & $\begin{array}{l}\text { COVID-19 Vaccine AstraZeneca } \\
\text { (AZD1222) }\end{array}$ & 18 years of age and older [91] & $\begin{array}{l}\text { Injection site pain or tenderness, tiredness, } \\
\text { headachemuscle pain, fever and chills }\end{array}$ & $\begin{array}{l}\text { UK, South Korea, Saudi Arabia, Phillipines, India, } \\
\text { Germany, France, Canada, Brazil, Australia }\end{array}$ \\
\hline 4 & Convidecia $^{\mathrm{TM}}$ (Ad5-nCoV) & 18 years of age and older [155] & $\begin{array}{l}\text { Injection site pain, mild to severe fever (up to grade 3), } \\
\text { headache, mild to severe fatigue (up to grade 3), muscle } \\
\text { and joint pain, throat pain and cough. }\end{array}$ & China, Pakistan \\
\hline 5 & Ad26.COV2.S & 18 years of age and older [95] & $\begin{array}{l}\text { Arm (pain, redness, swelling), body (tiredness, } \\
\text { headache, muscle pain, chills, fever, nausea) }\end{array}$ & US, South Africa, The Netherlands \\
\hline 6 & BBIBP-CorV & 18 years of age and older [98] & Headaches, fatigue, injection site reactions & China, Hungary, UAE \\
\hline 7 & Inactivated SARS-CoV-2 (vero cell) & 18 years of age and older & $\begin{array}{l}\text { Injection site pain, followed by fever, which were mild } \\
\text { and self-limiting }\end{array}$ & China, UAE \\
\hline 8 & CoronaVac & 18 years of age and older [99] & $\begin{array}{l}\text { Injection site reactions, fatigue, diarrhea, and muscle } \\
\text { pain }\end{array}$ & China, Brazil, Turkey, Indonesia, Phillipines \\
\hline 9 & Sputnik V & $\mathrm{N} / \mathrm{A}$ & Headaches, pain at injection site & Russia \\
\hline 10 & EpiVacCorona & $\mathrm{N} / \mathrm{A}$ & $\mathrm{N} / \mathrm{A}$ & Turkmenistan, Russia \\
\hline 11 & ZF2001/RBD-Dimer & $\mathrm{N} / \mathrm{A}$ & $\begin{array}{l}\text { Common mild side-effects including injection pain, } \\
\text { redness and swelling }\end{array}$ & China, Uzbekistan \\
\hline 12 & Soberana 2/Pasteur & $\mathrm{N} / \mathrm{A}$ & Pain and redness at the injection site, general malaise & Iran \\
\hline 13 & Abdala/CIGB-66 & $\mathrm{N} / \mathrm{A}$ & No serious adverse side effect & Cuba \\
\hline 14 & Medigen & $\mathrm{N} / \mathrm{A}$ & No vaccine-related serious adverse effects & Taiwan \\
\hline 15 & Covaxin $^{\circledR}$ & 18 years of age and old-er [156] & $\begin{array}{c}\text { Fever, headaches, irritability, pain, swelling, or both at } \\
\text { the site of injection }\end{array}$ & India \\
\hline
\end{tabular}


Table A1. Cont.

\begin{tabular}{|c|c|c|c|c|}
\hline No & Vaccine Name & Age Group & Common Side Effect(s) & Main User-Country \\
\hline 16 & QazCovid-in ${ }^{\circledR}$ & $\mathrm{N} / \mathrm{A}$ & No serious side effects & Kazakhstan \\
\hline 17 & Inactivated (Vero Cells) & $\mathrm{N} / \mathrm{A}$ & $\mathrm{N} / \mathrm{A}$ & China \\
\hline 18 & COVIran Barekat & $\mathrm{N} / \mathrm{A}$ & $\mathrm{N} / \mathrm{A}$ & Iran \\
\hline 19 & CoviVac & $\mathrm{N} / \mathrm{A}$ & $\mathrm{N} / \mathrm{A}$ & Russia \\
\hline 20 & NVX-CoV2373 & $\mathrm{N} / \mathrm{A}$ & $\mathrm{N} / \mathrm{A}$ & Indonesia, Denmark \\
\hline 21 & ZyCoV-D & $\mathrm{N} / \mathrm{A}$ & $\mathrm{N} / \mathrm{A}$ & India \\
\hline 22 & $\operatorname{COVAX}-19^{\circledR}$ & $\mathrm{N} / \mathrm{A}$ & $\mathrm{N} / \mathrm{A}$ & Iran \\
\hline 23 & Soberana Plus & $\mathrm{N} / \mathrm{A}$ & $\mathrm{N} / \mathrm{A}$ & Cuba \\
\hline
\end{tabular}

\section{Appendix B}

Table A2. COVID-19 vaccine candidates in phase 1-3 clinical trial as per 15 November 2021 [56].

\begin{tabular}{|c|c|c|c|c|c|c|c|c|c|c|}
\hline No & $\begin{array}{l}\text { Vaccine } \\
\text { Candidate }\end{array}$ & Developer & Vaccine Type & $\begin{array}{l}\text { Developer } \\
\text { Country }\end{array}$ & $\begin{array}{c}\text { Trial } \\
\text { Phase }\end{array}$ & Clinical Trial ID & Country & $\begin{array}{c}\text { Enrolment } \\
\text { Target }\end{array}$ & $\begin{array}{l}\text { Actual/Estimated } \\
\text { Trial Dates }\end{array}$ & Primary Outcome Measures \\
\hline 1 & $\begin{array}{l}\text { Gam-COVID- } \\
\text { Vac } \\
\text { Sputnik V }\end{array}$ & $\begin{array}{l}\text { Gamaleya } \\
\text { Research } \\
\text { Institute }\end{array}$ & $\begin{array}{l}\text { Viral vector } \\
\text { (non- } \\
\text { replicating) }\end{array}$ & Russia & 3 & NCT04530396 & Russia & 33,758 & $\begin{array}{c}7 \text { September } 2020- \\
1 \text { May } 2021\end{array}$ & $\begin{array}{c}\text { Percentage of trial subjects } \\
\text { with COVID-19 developed } \\
\text { within } 6 \text { months after the first } \\
\text { dose }\end{array}$ \\
\hline 2 & $\begin{array}{l}\text { NVX- } \\
\text { CoV2373 }\end{array}$ & Novavax & $\begin{array}{l}\text { Protein } \\
\text { subunit }\end{array}$ & US & 3 & NCT04611802 & $\begin{array}{l}\text { Mexico, } \\
\text { Puerto Rico, } \\
\text { US }\end{array}$ & 33,000 & $\begin{array}{l}27 \text { December } 2020- \\
30 \text { June } 2023\end{array}$ & $\begin{array}{l}\text { Participants with symptoms, } \\
\text { reactogenicity incidence and } \\
\text { severity; incidence and } \\
\text { severity of MAAEs, } \\
\text { UnSoAEs, SAEs, AESIs; } \\
\text { antibodies to SARS-CoV-2 } \\
\text { Nucleoprotein (NP); deaths } \\
\text { due to any cause }\end{array}$ \\
\hline
\end{tabular}


Table A2. Cont.

\begin{tabular}{|c|c|c|c|c|c|c|c|c|c|c|}
\hline No & $\begin{array}{l}\text { Vaccine } \\
\text { Candidate }\end{array}$ & Developer & Vaccine Type & $\begin{array}{l}\text { Developer } \\
\text { Country }\end{array}$ & $\begin{array}{l}\text { Trial } \\
\text { Phase }\end{array}$ & Clinical Trial ID & Country & $\begin{array}{l}\text { Enrolment } \\
\text { Target }\end{array}$ & $\begin{array}{l}\text { Actual/Estimated } \\
\text { Trial Dates }\end{array}$ & Primary Outcome Measures \\
\hline 3 & $\begin{array}{l}\text { ZF2001/RBD- } \\
\text { Dimer }\end{array}$ & $\begin{array}{l}\text { Anhui Zhifei } \\
\text { Longcom }\end{array}$ & $\begin{array}{l}\text { Protein } \\
\text { subunit }\end{array}$ & China & 3 & NCT04646590 & $\begin{array}{l}\text { China, } \\
\text { Ecuador, } \\
\text { Indonesia, } \\
\text { Pakistan, } \\
\text { Uzbekistan }\end{array}$ & 29,000 & $\begin{array}{l}16 \text { December 2020- } \\
\text { April } 2022\end{array}$ & $\begin{array}{c}\text { Endpoints of efficacy and } \\
\text { safety }\end{array}$ \\
\hline 4 & $\mathrm{CVnCoV}$ & Curevac & $\begin{array}{l}\text { RNA based } \\
\text { vaccine }\end{array}$ & Germany & 3 & NCT04652102 & Germany & 36,500 & $\begin{array}{l}14 \text { December 2020- } \\
15 \text { May } 2022\end{array}$ & $\begin{array}{c}\text { Participants with } \\
\text { virologically confirmed PCR } \\
\text { positive cases of COVID-19 } \\
\text { of any severity; participant } \\
\text { with MAAEs, SAEs, AESIs }\end{array}$ \\
\hline 5 & $\begin{array}{l}\text { Inactivated } \\
\text { (Vero Cells) }\end{array}$ & $\begin{array}{l}\text { Chinese } \\
\text { Academy of } \\
\text { Medical } \\
\text { Sciences }\end{array}$ & $\begin{array}{l}\text { Inactivated } \\
\text { virus }\end{array}$ & China & 3 & NCT04659239 & $\begin{array}{l}\text { Brazil, } \\
\text { Malaysia }\end{array}$ & 34,020 & $\begin{array}{l}28 \text { January } 2021- \\
\text { July } 2022\end{array}$ & $\begin{array}{l}\text { Incidence of COVID-19 cases } \\
\text { after two-doses of } \\
\text { vaccination, the incidence of } \\
\text { SoAEs }\end{array}$ \\
\hline 6 & QazCovid-in ${ }^{\circledR}$ & $\begin{array}{l}\text { Research } \\
\text { Institute for } \\
\text { Biological } \\
\text { Safety } \\
\text { Problems } \\
\text { Kazakhstan }\end{array}$ & $\begin{array}{l}\text { Inactivated } \\
\text { virus }\end{array}$ & Kazakhstan & 3 & NCT04691908 & Kazakhstan & 3000 & $\begin{array}{l}25 \text { December } 2020- \\
30 \text { July } 2021\end{array}$ & $\begin{array}{l}\text { Seroconversion; vaccine } \\
\text { immunogenicity versus } \\
\text { placebo, frequency of } \\
\text { confirmed COVID-19 cases }\end{array}$ \\
\hline 7 & ZyCoV-D & Zydus Cadila & $\begin{array}{l}\text { DNA based } \\
\text { vaccine }\end{array}$ & India & 3 & $\begin{array}{l}\text { CTRI/2021/ } \\
01 / 030416\end{array}$ & India & 28,216 & $\mathrm{~N} / \mathrm{A}$ & $\begin{array}{l}\text { To demonstrate the efficacy } \\
\text { of ZyCoV-D in the prevention } \\
\text { of virologically confirmed } \\
\text { symptomatic COVID-19 } \\
\text { cases as compared to placebo }\end{array}$ \\
\hline 8 & Covaxin & Bharat Biotech & $\begin{array}{l}\text { Inactivated } \\
\text { virus }\end{array}$ & India & 3 & NCT04641481 & India & 25,800 & $\begin{array}{l}16 \text { November 2020- } \\
\text { December } 2022\end{array}$ & $\begin{array}{c}\text { First occurrence of } \\
\text { virologically confirmed } \\
\text { (RT-PCR positive) } \\
\text { symptomatic COVID-19 } \\
\text { cases }\end{array}$ \\
\hline
\end{tabular}


Table A2. Cont.

\begin{tabular}{|c|c|c|c|c|c|c|c|c|c|c|}
\hline No & $\begin{array}{l}\text { Vaccine } \\
\text { Candidate }\end{array}$ & Developer & Vaccine Type & $\begin{array}{l}\text { Developer } \\
\text { Country }\end{array}$ & $\begin{array}{l}\text { Trial } \\
\text { Phase }\end{array}$ & Clinical Trial ID & Country & $\begin{array}{c}\text { Enrolment } \\
\text { Target }\end{array}$ & $\begin{array}{c}\text { Actual/Estimated } \\
\text { Trial Dates }\end{array}$ & Primary Outcome Measures \\
\hline 9 & $\begin{array}{c}\text { VAT00002: } \\
\text { with adjuvant }\end{array}$ & Sanofi/GSK & $\begin{array}{l}\text { Protein } \\
\text { subunit }\end{array}$ & US & 3 & NCT04904549 & US & 37,430 & $\begin{array}{c}26 \text { May 2021- } \\
13 \text { January } 2023\end{array}$ & $\begin{array}{l}\text { Occurrence of symptomatic } \\
\text { COVID-19, presence of } \\
\text { injection site or systemic } \\
\text { reactions, non-serious } \\
\text { UnSoAEs, immediate AEs, } \\
\text { MAAEs, SAEs, AESIs, and } \\
\text { virologically confirmed } \\
\text { SARS-CoV-2 infections } \\
\text { and/or symptomatic } \\
\text { COVID-19 }\end{array}$ \\
\hline 10 & $\begin{array}{l}\text { Inactivated } \\
\text { (Vero Cells) }\end{array}$ & $\begin{array}{l}\text { Shenzhen } \\
\text { Kangtai } \\
\text { Biological } \\
\text { Products Co., } \\
\text { Ltd. }\end{array}$ & $\begin{array}{l}\text { Inactivated } \\
\text { virus }\end{array}$ & China & 3 & NCT04852705 & China & 28,000 & $\begin{array}{c}\text { May 2021- } \\
\text { November } 2022\end{array}$ & $\begin{array}{c}\text { Incidence density of } \\
\text { symptomatic COVID-19 } \\
\text { cases }\end{array}$ \\
\hline 11 & $\begin{array}{l}\text { FINLAY-FR-2 } \\
\text { anti-SARS- } \\
\text { CoV-2 } \\
\text { Vaccine }\end{array}$ & $\begin{array}{l}\text { Instituto } \\
\text { Finlay de } \\
\text { Vacunas }\end{array}$ & $\begin{array}{l}\text { Protein } \\
\text { subunit }\end{array}$ & Cuba & 3 & IFV/COR/09 & Cuba & 44,010 & $\mathrm{~N} / \mathrm{A}$ & $\begin{array}{l}\text { Virologically confirmed } \\
\text { symptomatic COVID-19 } \\
\text { infection }\end{array}$ \\
\hline 12 & EpiVacCorona & FBRI & $\begin{array}{l}\text { Protein } \\
\text { subunit }\end{array}$ & Russia & 3 & NCT04780035 & Russia & 3000 & $\begin{array}{l}18 \text { November } 2020- \\
\text { September } 2021\end{array}$ & $\begin{array}{l}\text { The proportion of vaccinated } \\
\text { volunteers with no laboratory } \\
\text { confirmed symptoms caused } \\
\text { by SARS-CoV-2, within } 6 \\
\text { months post vaccination } \\
\text { versus placebo, the } \\
\text { prophylactic efficacy of the } \\
\text { vaccine }\end{array}$ \\
\hline
\end{tabular}


Table A2. Cont.

\begin{tabular}{|c|c|c|c|c|c|c|c|c|c|c|}
\hline No & $\begin{array}{l}\text { Vaccine } \\
\text { Candidate }\end{array}$ & Developer & Vaccine Type & $\begin{array}{l}\text { Developer } \\
\text { Country }\end{array}$ & $\begin{array}{l}\text { Trial } \\
\text { Phase }\end{array}$ & Clinical Trial ID & Country & $\begin{array}{l}\text { Enrolment } \\
\text { Target }\end{array}$ & $\begin{array}{l}\text { Actual/Estimated } \\
\text { Trial Dates }\end{array}$ & Primary Outcome Measures \\
\hline 13 & $\begin{array}{l}\text { Recombinant } \\
\text { (Sf9 cell) }\end{array}$ & $\begin{array}{l}\text { West China } \\
\text { Hospital }\end{array}$ & $\begin{array}{l}\text { Protein } \\
\text { subunit }\end{array}$ & China & 3 & NCT04904471 & China & 40,000 & $\begin{array}{l}1 \text { June 2021- } \\
31 \text { December } 2022\end{array}$ & $\begin{array}{c}\text { Virologically confirmed } \\
\text { (polymerase chain reaction } \\
\text { [PCR] positive) symptomatic } \\
\text { COVID-19 cases at first } \\
\text { appearance, regardless of } \\
\text { severity; incidence of SAEs, } \\
\text { AESIs, MAAEs, SoAEs, } \\
\text { UnSoAEs }\end{array}$ \\
\hline 14 & $\begin{array}{c}\text { mRNA } \\
\text { vaccine } \\
(\mathrm{ARCoV})\end{array}$ & $\begin{array}{c}\text { Academy of } \\
\text { Military } \\
\text { Science (AMS), } \\
\text { Walvax } \\
\text { Biotechnology }\end{array}$ & $\begin{array}{l}\text { RNA based } \\
\text { vaccine }\end{array}$ & China & 3 & NCT04847102 & $\mathrm{N} / \mathrm{A}$ & 28,000 & $\begin{array}{l}28 \text { May 2021- } \\
30 \text { May } 2023\end{array}$ & $\begin{array}{c}\text { Incidence rate (person-year) } \\
\text { of COVID-19 cases, AEs, and } \\
\text { SAEs }\end{array}$ \\
\hline 15 & CIGB-66 & $\begin{array}{l}\text { Center for } \\
\text { Genetic } \\
\text { Engineering } \\
\text { and } \\
\text { Biotechnology } \\
\text { (CIGB) }\end{array}$ & $\begin{array}{l}\text { Protein } \\
\text { subunit }\end{array}$ & Cuba & 3 & RPCEC00000359 & Cuba & 48,000 & $\mathrm{~N} / \mathrm{A}$ & $\begin{array}{l}\text { Vaccine efficacy (number of } \\
\text { symptomatic COVID-19 } \\
\text { subjects with no evidence of } \\
\text { previous exposure to viral } \\
\text { infection) }\end{array}$ \\
\hline 16 & VLA2001 & Valneva & $\begin{array}{l}\text { Inactivated } \\
\text { virus }\end{array}$ & France & 3 & NCT04864561 & UK & 4000 & $\begin{array}{l}26 \text { April 2021- } \\
30 \text { June } 2022\end{array}$ & $\begin{array}{l}\text { Immune response measured } \\
\text { after completion of a 2-dose } \\
\text { immunization schedule, as } \\
\text { determined by the GMT of } \\
\text { SARS-CoV-2-specific } \\
\text { neutralizing antibodies, } \\
\text { frequency and severity of any } \\
\text { AEs }\end{array}$ \\
\hline
\end{tabular}


Table A2. Cont.

\begin{tabular}{|c|c|c|c|c|c|c|c|c|c|c|}
\hline No & $\begin{array}{l}\text { Vaccine } \\
\text { Candidate }\end{array}$ & Developer & Vaccine Type & $\begin{array}{l}\text { Developer } \\
\text { Country }\end{array}$ & $\begin{array}{l}\text { Trial } \\
\text { Phase }\end{array}$ & Clinical Trial ID & Country & $\begin{array}{l}\text { Enrolment } \\
\text { Target }\end{array}$ & $\begin{array}{l}\text { Actual/Estimated } \\
\text { Trial Dates }\end{array}$ & Primary Outcome Measures \\
\hline 17 & Nanocovax & $\begin{array}{l}\text { Nanogen Phar- } \\
\text { maceutical } \\
\text { Biotechnology }\end{array}$ & $\begin{array}{l}\text { Protein } \\
\text { Subunit }\end{array}$ & Viet Nam & 3 & NCT04922788 & Viet Nam & 13,000 & $\begin{array}{l}7 \text { June 2021- } \\
7 \text { August } 2022\end{array}$ & $\begin{array}{c}\text { Participants who experience } \\
\text { a first episode of virologically } \\
\text { confirmed case of COVID-19; } \\
\text { any severity SAEs, MAAEs; } \\
\text { geometric mean of anti-S IgG } \\
\text { concentrations; geometric } \\
\text { mean of SARS-CoV-2 serum } \\
\text { neutralizing titres by plaque } \\
\text { reduction neutralization test } \\
\text { (PRNT) }\end{array}$ \\
\hline 18 & $\begin{array}{l}\text { ERUCOV- } \\
\text { VAC } \\
\text { (Turkovac) }\end{array}$ & $\begin{array}{l}\text { Erciyes } \\
\text { University }\end{array}$ & $\begin{array}{l}\text { Inactivated } \\
\text { virus }\end{array}$ & Turkey & 3 & NCT04942405 & Turkey & 40,800 & $\begin{array}{l}21 \text { June 2021- } \\
31 \text { March } 2023\end{array}$ & $\begin{array}{c}\text { Protection indexes of two } \\
\text { vaccine doses for } \\
\text { symptomatic COVID-19, } \\
2 \text { weeks after the second dose } \\
\text { of vaccination }\end{array}$ \\
\hline 19 & ARCT-154 & $\begin{array}{c}\text { Arcturus } \\
\text { Therapeutics } \\
\text { Inc }\end{array}$ & $\begin{array}{l}\text { RNA based } \\
\text { vaccine }\end{array}$ & US & 3 & ISRCTN15779782 & Switzerland & $\mathrm{N} / \mathrm{A}$ & $\begin{array}{l}3 \text { August 2021- } \\
1 \text { September } 2023\end{array}$ & $\begin{array}{c}\text { Percentage of participants } \\
\text { with virologically confirmed } \\
\text { COVID-19 }\end{array}$ \\
\hline 20 & INO-4800 & $\begin{array}{l}\text { Inovio Phar- } \\
\text { maceuticals }\end{array}$ & $\begin{array}{l}\text { DNA based } \\
\text { vaccine }\end{array}$ & US & 3 & ISRCTN15779782 & Switzerland & $\mathrm{N} / \mathrm{A}$ & $\begin{array}{l}3 \text { August 2021- } \\
1 \text { September } 2023\end{array}$ & $\begin{array}{c}\text { Percentage of participants } \\
\text { with virologically confirmed } \\
\text { COVID-19 }\end{array}$ \\
\hline 21 & SCB-2019 & $\begin{array}{l}\text { Clover Bio- } \\
\text { pharmaceuti- } \\
\text { cals/GSK/Dynavax }\end{array}$ & $\begin{array}{l}\text { Protein } \\
\text { subunit }\end{array}$ & Australia & 3 & NCT05012787 & $\begin{array}{l}\text { South Africa, } \\
\text { Ukraine }\end{array}$ & 300 & $\begin{array}{l}13 \text { September 2021- } \\
16 \text { December } 2022\end{array}$ & $\begin{array}{l}\text { Participants with AEs, } \\
\text { UnSoAEs, SAEs, MAAEs, } \\
\text { AESIs, any confirmed relapse } \\
\text { of immune-mediated disease }\end{array}$ \\
\hline 22 & CoVLP & Medicago & $\begin{array}{l}\text { Virus like } \\
\text { particle }\end{array}$ & Canada & 3 & NCT04636697 & Canada, US & 900 & $\begin{array}{l}22 \text { November 2021- } \\
31 \text { May } 2022\end{array}$ & $\begin{array}{c}\text { GMTs of the three vaccine } \\
\text { lots }\end{array}$ \\
\hline 23 & COVAX-19 ${ }^{\circledR}$ & $\begin{array}{c}\text { Vaxine } \\
\text { Pty.Ltd/Cinnagen } \\
\text { Co. }\end{array}$ & $\begin{array}{l}\text { Protein } \\
\text { Subunit }\end{array}$ & Australia & 2 & $\begin{array}{l}\text { IRCT201503030- } \\
\text { 21315N24 }\end{array}$ & Iran & 16,876 & $\mathrm{~N} / \mathrm{A}$ & $\begin{array}{c}\text { Evaluation of COVID-19 } \\
\text { incidence }\end{array}$ \\
\hline
\end{tabular}


Table A2. Cont.

\begin{tabular}{|c|c|c|c|c|c|c|c|c|c|c|}
\hline No & $\begin{array}{l}\text { Vaccine } \\
\text { Candidate }\end{array}$ & Developer & Vaccine Type & $\begin{array}{l}\text { Developer } \\
\text { Country }\end{array}$ & $\begin{array}{l}\text { Trial } \\
\text { Phase }\end{array}$ & Clinical Trial ID & Country & $\begin{array}{l}\text { Enrolment } \\
\text { Target }\end{array}$ & $\begin{array}{l}\text { Actual/Estimated } \\
\text { Trial Dates }\end{array}$ & Primary Outcome Measures \\
\hline 24 & $\begin{array}{l}\text { DelNS1-2019- } \\
\text { nCoV-RBD- } \\
\text { OPT1 }\end{array}$ & $\begin{array}{l}\text { The University } \\
\text { of Hong Kong } \\
\text { and Xiamen } \\
\text { University }\end{array}$ & $\begin{array}{l}\text { Viral vector } \\
\text { (Replicating) }\end{array}$ & Hong Kong & 2 & ChiCTR2100051391 & Hong Kong & $\mathrm{N} / \mathrm{A}$ & $\mathrm{N} / \mathrm{A}$ & $\mathrm{N} / \mathrm{A}$ \\
\hline 25 & BECOV2 & $\begin{array}{l}\text { Biological E } \\
\text { Limited }\end{array}$ & $\begin{array}{l}\text { Protein } \\
\text { subunit }\end{array}$ & India & 3 & $\begin{array}{l}\text { CTRI/2021/ } \\
08 / 036074\end{array}$ & India & 2140 & $\mathrm{~N} / \mathrm{A}$ & $\begin{array}{l}\text { Immune response measured } \\
\text { after completion of 2-dose } \\
\text { immunization schedule, as } \\
\text { determined by GMT/C }\end{array}$ \\
\hline 26 & GBP510 & $\begin{array}{l}\text { SK Bioscience } \\
\text { Co., Ltd. and } \\
\text { CEPI }\end{array}$ & $\begin{array}{l}\text { Protein } \\
\text { subunit }\end{array}$ & South Korea & 3 & NCT05007951 & South Korea & 3990 & $\begin{array}{l}30 \text { August 2021- } \\
\text { September } 2022\end{array}$ & $\begin{array}{l}\text { GMT of SARS-CoV-2 } \\
\text { neutralizing antibody }\end{array}$ \\
\hline 27 & COVI-VAC & Codagenix Inc & $\begin{array}{c}\text { Live- } \\
\text { Attenuated }\end{array}$ & US & 3 & ISRCTN15779782 & Switzerland & $\mathrm{N} / \mathrm{A}$ & $\begin{array}{l}3 \text { August 2021- } \\
1 \text { September } 2023\end{array}$ & $\begin{array}{l}\text { Percentage of participants } \\
\text { with virologically confirmed } \\
\text { COVID-19 }\end{array}$ \\
\hline 28 & Razi Cov Pars & $\begin{array}{l}\text { Razi Vaccine } \\
\text { and Serum } \\
\text { Research } \\
\text { Institute }\end{array}$ & $\begin{array}{l}\text { Protein } \\
\text { subunit }\end{array}$ & Iran & 2 & $\begin{array}{l}\text { IRCT202102060- } \\
\text { 50259N3 }\end{array}$ & Iran & 41,128 & $\mathrm{~N} / \mathrm{A}$ & $\begin{array}{l}\text { Occurrence of confirmed } \\
\text { symptomatic COVID-19 } \\
\text { disease two weeks after the } \\
\text { second vaccine dose }\end{array}$ \\
\hline 29 & $\begin{array}{l}\text { AG0301- } \\
\text { COVID19 }\end{array}$ & $\begin{array}{c}\text { AnGes + } \\
\text { Takarabio + } \\
\text { Osaka } \\
\text { University }\end{array}$ & $\begin{array}{l}\text { DNA based } \\
\text { vaccine }\end{array}$ & Japan & $2 / 3$ & NCT04655625 & Japan & 500 & $\begin{array}{l}23 \text { November } 2020- \\
31 \text { March } 2022\end{array}$ & $\begin{array}{l}\text { Incidence of } \\
\text { treatment-emergent AEs; } \\
\text { Immunogenicity }\end{array}$ \\
\hline 30 & GRAd-COV2 & ReiThera & $\begin{array}{l}\text { Viral vector } \\
\quad \text { (non- } \\
\text { replicating) }\end{array}$ & Italy & $2 / 3$ & NCT04791423 & Italy & 10,300 & $\begin{array}{l}15 \text { March 2021- } \\
30 \text { April } 2022\end{array}$ & $\begin{array}{c}\text { Participants with } \\
\text { symptomatic laboratory } \\
\text { confirmed COVID-19, } \\
\text { incidence of AEs, SAEs, } \\
\text { MAAEs, and AESIs, local and } \\
\text { systemic SoAEs, } \\
\text { post-treatment GMTs and } \\
\text { GMFRs in SARS-CoV-2 S } \\
\text { and/or RBD antibodies }\end{array}$ \\
\hline
\end{tabular}


Table A2. Cont.

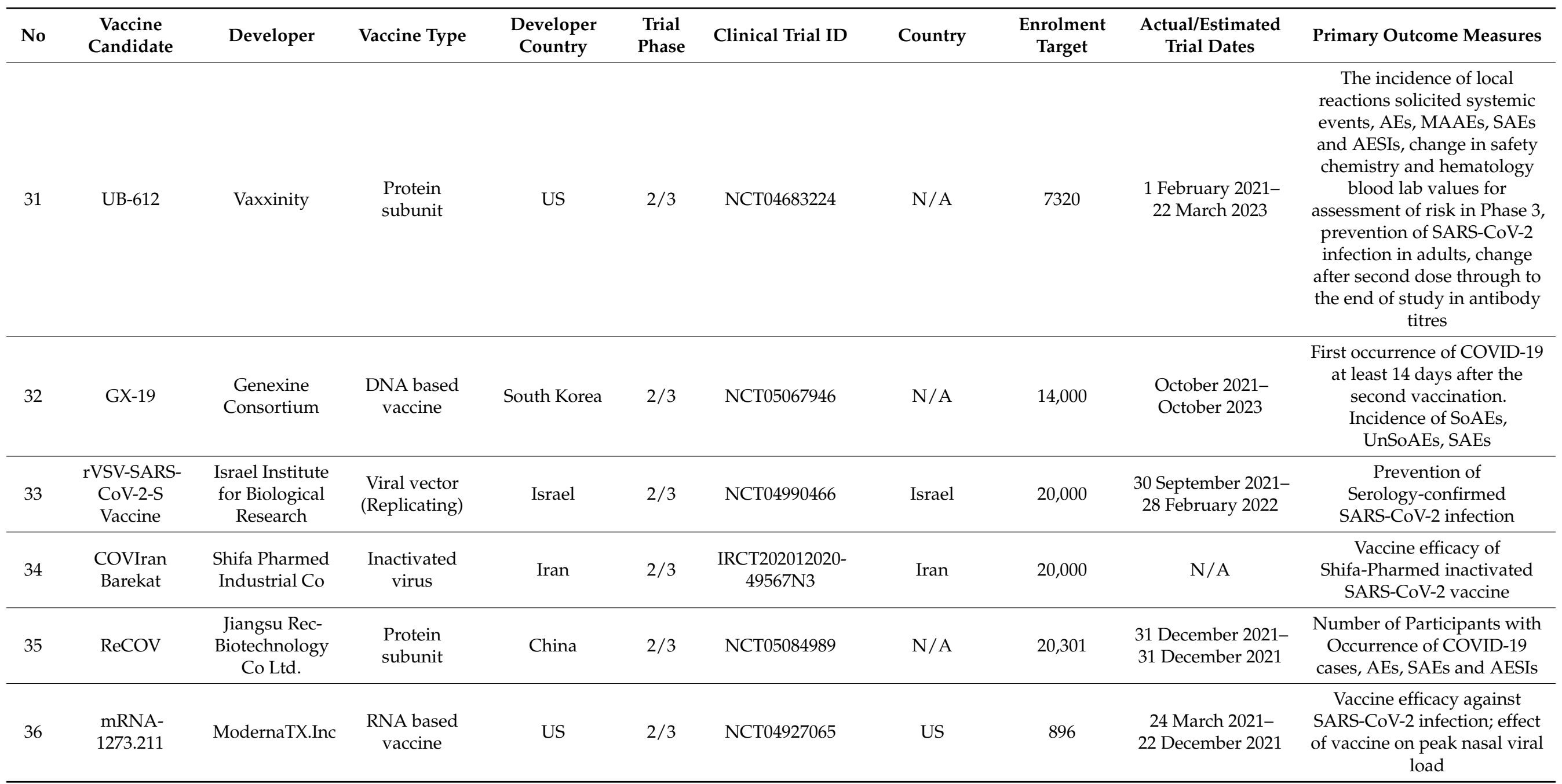


Table A2. Cont.

\begin{tabular}{|c|c|c|c|c|c|c|c|c|c|c|}
\hline No & $\begin{array}{l}\text { Vaccine } \\
\text { Candidate }\end{array}$ & Developer & Vaccine Type & $\begin{array}{l}\text { Developer } \\
\text { Country }\end{array}$ & $\begin{array}{l}\text { Trial } \\
\text { Phase }\end{array}$ & Clinical Trial ID & Country & $\begin{array}{l}\text { Enrolment } \\
\text { Target }\end{array}$ & $\begin{array}{l}\text { Actual/Estimated } \\
\text { Trial Dates }\end{array}$ & Primary Outcome Measures \\
\hline 37 & AZD2816 & $\begin{array}{l}\text { AstraZeneca } \\
\text { and The } \\
\text { University of } \\
\text { Oxford }\end{array}$ & $\begin{array}{l}\text { Viral vector } \\
\text { (non- } \\
\text { replicating) }\end{array}$ & UK & $2 / 3$ & NCT04973449 & UK & 2475 & $\begin{array}{l}27 \text { June } 2021- \\
15 \text { June } 2022\end{array}$ & $\begin{array}{c}\text { Safety and tolerability of } \\
1 \text { dose of AZD2816 in } \\
\text { seronegative participants } \\
\text { previously vaccinated with } \\
\text { AZD1222, and } 2 \text { doses in } \\
\text { unvaccinated seronegative } \\
\text { participants }\end{array}$ \\
\hline 38 & SCTV01C & $\begin{array}{l}\text { Sinocelltech } \\
\text { Ltd. }\end{array}$ & $\begin{array}{l}\text { Protein } \\
\text { Subunit }\end{array}$ & China & $2 / 3$ & NCT05043311 & $\mathrm{N} / \mathrm{A}$ & 12,420 & $\begin{array}{c}30 \text { October 2021- } \\
1 \text { October } 2022\end{array}$ & $\begin{array}{l}\text { The incidence of COVID-19 } \\
\text { infections }\end{array}$ \\
\hline 39 & FINLAY-FR-1 & $\begin{array}{c}\text { Instituto } \\
\text { Finlay de } \\
\text { Vacunas Cuba }\end{array}$ & $\begin{array}{l}\text { Protein } \\
\text { subunit }\end{array}$ & Cuba & 2 & IFV/COR/04 & Cuba & 676 & $\begin{array}{l}13 \text { August 2020- } \\
11 \text { January } 2021\end{array}$ & $\begin{array}{c}\text { SAEs, titre of specific } \\
\text { anti-RBD IgG antibodies at } \\
\text { baseline and 14, } 28 \text { and } \\
56 \text { days }\end{array}$ \\
\hline 40 & $\begin{array}{l}\text { LUNAR- } \\
\text { COV19/ARCT- } \\
021\end{array}$ & $\begin{array}{c}\text { Arcturus } \\
\text { Therapeutics } \\
\text { Inc }\end{array}$ & $\begin{array}{l}\text { RNA based } \\
\text { vaccine }\end{array}$ & US & 2 & NCT04668339 & Singapore, US & 600 & $\begin{array}{l}7 \text { January 2021- } \\
30 \text { April } 2022\end{array}$ & $\begin{array}{l}\text { Local and systemic SoAEs, } \\
\text { AEs, SAEs, MAAEs, new } \\
\text { onset of chronic disease, } \\
\text { abnormal chemistry and } \\
\text { hematology values; GMT and } \\
\text { GMFR of neutralizing } \\
\text { antibody }\end{array}$ \\
\hline 41 & VXA-CoV2-1 & Vaxart & $\begin{array}{l}\text { Viral vector } \\
\text { (non- } \\
\text { replicating) }\end{array}$ & US & 2 & NCT05067933 & US & 896 & $\begin{array}{l}\text { October 2020- } \\
\text { June } 2023\end{array}$ & $\begin{array}{c}\text { Rate of UnSoAEs, frequency } \\
\text { of SAEs and MAAEs }\end{array}$ \\
\hline 42 & $\begin{array}{l}\text { Dendritic cell } \\
\text { vaccine } \\
\text { AV-COVID-19 }\end{array}$ & $\begin{array}{c}\text { Aivita } \\
\text { Biomedical, } \\
\text { Inc + Ministry } \\
\text { of Health } \\
\text { Republic of } \\
\text { Indonesia }\end{array}$ & $\begin{array}{l}\text { Viral vector } \\
\text { (Replicating) }+ \\
\text { APC }\end{array}$ & US & 2 & NCT05007496 & Indonesia & 145 & $\begin{array}{l}\text { April 2021-May } \\
2021\end{array}$ & $\begin{array}{l}\text { Efficacy based on } \\
\text { T-cell-induced immune } \\
\text { response }\end{array}$ \\
\hline
\end{tabular}


Table A2. Cont.

\begin{tabular}{|c|c|c|c|c|c|c|c|c|c|c|}
\hline No & $\begin{array}{l}\text { Vaccine } \\
\text { Candidate }\end{array}$ & Developer & Vaccine Type & $\begin{array}{l}\text { Developer } \\
\text { Country }\end{array}$ & $\begin{array}{l}\text { Trial } \\
\text { Phase }\end{array}$ & Clinical Trial ID & Country & $\begin{array}{l}\text { Enrolment } \\
\text { Target }\end{array}$ & $\begin{array}{c}\text { Actual/Estimated } \\
\text { Trial Dates }\end{array}$ & Primary Outcome Measures \\
\hline 43 & MRT5500 & Sanofi Pasteur & $\begin{array}{l}\text { RNA based } \\
\text { vaccine }\end{array}$ & US & 2 & NCT04798027 & US & 333 & $\begin{array}{l}12 \text { March 2021- } \\
\text { July } 2022\end{array}$ & $\begin{array}{l}\text { Presence of immediate AEs, } \\
\text { solicited injection site } \\
\text { reactions and systemic } \\
\text { reactions, UnSoAEs, MAAEs, } \\
\text { and AESIs; Presence of } \\
\text { out-of-range biological test } \\
\text { results, neutralizing antibody } \\
\text { titre, seroconversion }\end{array}$ \\
\hline 44 & $\begin{array}{l}\text { SARS-CoV-2 } \\
\text { VLP Vaccine }\end{array}$ & $\begin{array}{c}\text { The Scientific } \\
\text { and } \\
\text { Technological } \\
\text { Research } \\
\text { Council of } \\
\text { Turkey }\end{array}$ & $\begin{array}{l}\text { Virus like } \\
\text { particle }\end{array}$ & Turkey & 2 & NCT04962893 & Turkey & 330 & $\begin{array}{l}26 \text { June 2021- } \\
\text { September } 2022\end{array}$ & $\begin{array}{l}\text { Comparison of efficacy, } \\
\text { specific IgG, neutralizing } \\
\text { antibody, and cellular } \\
\text { immune response }\end{array}$ \\
\hline 45 & $\begin{array}{l}\text { Recombinant } \\
\text { SARS-CoV-2 } \\
\text { Fusion Protein } \\
\text { Vaccine (V-01) }\end{array}$ & $\begin{array}{l}\text { Guangdong } \\
\text { Provincial } \\
\text { Center for } \\
\text { Disease } \\
\text { Control and } \\
\text { Prevention }\end{array}$ & $\begin{array}{l}\text { Protein } \\
\text { subunit }\end{array}$ & China & 2 & $\begin{array}{l}\text { ChiCTR21000- } \\
\quad 45107\end{array}$ & China & 880 & $\begin{array}{l}28 \text { March 2021- } \\
30 \text { July } 2022\end{array}$ & $\begin{array}{l}\text { Positive conversion rate of } \\
\text { serum anti-SARS-CoV-2 RBD } \\
\text { protein antibody, and its } \\
\text { GMT and GMI; positive } \\
\text { conversion rate of serum } \\
\text { anti-SARS-CoV-2 } \\
\text { neutralizing antibody, and its } \\
\text { GMI }\end{array}$ \\
\hline 46 & SCB-2020S & $\begin{array}{l}\text { Clover } \\
\text { Biopharma- } \\
\text { ceuticals AUS } \\
\text { Pty Ltd. }\end{array}$ & $\begin{array}{l}\text { Protein } \\
\text { subunit }\end{array}$ & Australia & 2 & NCT04950751 & $\mathrm{N} / \mathrm{A}$ & 150 & $\begin{array}{l}\text { August 2021- } \\
\text { April } 2020\end{array}$ & $\begin{array}{l}\text { GMT and GMFR of } \\
\text { SARS-CoV-2 neutralising } \\
\text { antibodies to B.1.351 variant, } \\
\text { proportion of subjects } \\
\text { achieving seroconversion of } \\
\text { SARS-CoV-2 neutralising } \\
\text { antibodies to B.1.351 variant }\end{array}$ \\
\hline 47 & SC-Ad6-1 & $\begin{array}{l}\text { Tetherex Phar- } \\
\text { maceuticals } \\
\text { Corporation }\end{array}$ & $\begin{array}{l}\text { Viral vector } \\
\text { (non- } \\
\text { replicating) }\end{array}$ & US & 2 & NCT05077267 & Germany & 210 & $\begin{array}{l}19 \text { August 2021- } \\
1 \text { February } 2024\end{array}$ & $\begin{array}{l}\text { SARS-CoV-2 neutralizing } \\
\text { antibody titers }\end{array}$ \\
\hline
\end{tabular}


Table A2. Cont.

\begin{tabular}{|c|c|c|c|c|c|c|c|c|c|c|}
\hline No & $\begin{array}{l}\text { Vaccine } \\
\text { Candidate }\end{array}$ & Developer & Vaccine Type & $\begin{array}{l}\text { Developer } \\
\text { Country }\end{array}$ & $\begin{array}{l}\text { Trial } \\
\text { Phase }\end{array}$ & Clinical Trial ID & Country & $\begin{array}{l}\text { Enrolment } \\
\text { Target }\end{array}$ & $\begin{array}{l}\text { Actual/Estimated } \\
\text { Trial Dates }\end{array}$ & Primary Outcome Measures \\
\hline 48 & $\begin{array}{l}\text { Recombinant } \\
\text { RBD Protein } \\
\text { Vaccine }\end{array}$ & $\begin{array}{l}\text { Bagheiat-allah } \\
\text { University of } \\
\text { Medical } \\
\text { Sciences }\end{array}$ & $\begin{array}{l}\text { Protein } \\
\text { subunit }\end{array}$ & Iran & 2 & $\begin{array}{l}\text { IRCT202106200- } \\
\text { 51639N2 }\end{array}$ & Iran & 300 & $\mathrm{~N} / \mathrm{A}$ & $\begin{array}{l}\text { IgG antibody against } \\
\text { Receptor Binding Domain } \\
\text { (RBD) protein }\end{array}$ \\
\hline 49 & KBP-201 & $\begin{array}{c}\text { Kentucky } \\
\text { Bioprocessing }\end{array}$ & $\begin{array}{l}\text { Protein } \\
\text { subunit }\end{array}$ & US & $1 / 2$ & NCT04473690 & US & 180 & $\begin{array}{l}31 \text { July } 2021- \\
31 \text { July } 2022\end{array}$ & $\begin{array}{l}\text { Solicited administration site } \\
\text { reactions and systemic events }\end{array}$ \\
\hline 50 & $\begin{array}{c}\text { RBD } \\
\text { SARS-CoV-2 } \\
\text { HBsAg VLP }\end{array}$ & $\begin{array}{l}\text { SpyBiotech + } \\
\text { Serum } \\
\text { Institute of } \\
\text { India }\end{array}$ & $\begin{array}{l}\text { Virus like } \\
\text { particle }\end{array}$ & UK & $1 / 2$ & $\begin{array}{c}\text { ACTRN1262- } \\
0000817943\end{array}$ & Australia & 280 & $\mathrm{~N} / \mathrm{A}$ & $\begin{array}{l}\text { To assess the immune } \\
\text { response, safety and } \\
\text { reactogenicity, of a two-dose } \\
\text { schedule of two dose } \\
\text { amounts of RBD SARS-CoV-2 } \\
\text { HBsAg VLP vaccine as } \\
\text { compared with two-dose } \\
\text { administration of placebo }\end{array}$ \\
\hline 51 & IMP CoVac-1 & $\begin{array}{l}\text { University } \\
\text { Hospital } \\
\text { Tuebingen }\end{array}$ & $\begin{array}{l}\text { Protein } \\
\text { subunit }\end{array}$ & Germany & $1 / 2$ & NCT04954469 & Germany & 68 & $\begin{array}{l}30 \text { June 2021- } \\
31 \text { March } 2022\end{array}$ & $\begin{array}{l}\text { Safety- Eastern Cooperative } \\
\text { Oncology Group (ECOG) } \\
\text { status, vital signs, blood } \\
\text { chemistry and coagulation, } \\
\text { and hematology }\end{array}$ \\
\hline 52 & $\begin{array}{l}\text { LV-SMENP- } \\
\text { DC }\end{array}$ & $\begin{array}{l}\text { Shenzhen } \\
\text { Geno-Immune } \\
\text { Medical } \\
\text { Institute }\end{array}$ & $\begin{array}{l}\text { Viral vector } \\
\text { (non- } \\
\text { replicating) + } \\
\text { APC }\end{array}$ & China & $1 / 2$ & NCT04276896 & China & 100 & $\begin{array}{l}24 \text { March 2020- } \\
31 \text { December 2024 }\end{array}$ & $\begin{array}{l}\text { Clinical improvement based } \\
\text { on the 7-point scale, lower } \\
\text { Murray lung injury score }\end{array}$ \\
\hline 53 & $\begin{array}{l}\text { hAd5-S+N } \\
\text { bivalent } \\
\text { vaccine }\end{array}$ & $\begin{array}{l}\text { ImmunityBio } \\
\text { Inc }\end{array}$ & $\begin{array}{l}\text { Viral vector } \\
\text { (non- } \\
\text { replicating) }\end{array}$ & US & $1 / 2$ & NCT04843722 & US & 540 & $\begin{array}{l}\text { May 2021- } \\
\text { August } 2022\end{array}$ & $\begin{array}{l}\text { Efficacy: percent of subjects } \\
\text { that show an increase in } \\
\text { N-reactive T cells }\end{array}$ \\
\hline 54 & CIGB-669 & $\begin{array}{l}\text { Center for } \\
\text { Genetic } \\
\text { Engineering } \\
\text { and } \\
\text { Biotechnology } \\
\text { (CIGB) }\end{array}$ & $\begin{array}{l}\text { Protein } \\
\text { subunit }\end{array}$ & Cuba & $1 / 2$ & RPCEC00000345 & Cuba & 88 & $\mathrm{~N} / \mathrm{A}$ & $\begin{array}{l}\text { Safety: occurrence and } \\
\text { intensity of AEs, subjects } \\
\text { with seroconversion of } \\
\text { anti-RBD IgG antibodies to } \\
\text { SARS-CoV-2 }\end{array}$ \\
\hline
\end{tabular}


Table A2. Cont.

\begin{tabular}{|c|c|c|c|c|c|c|c|c|c|c|}
\hline No & $\begin{array}{c}\text { Vaccine } \\
\text { Candidate }\end{array}$ & Developer & Vaccine Type & $\begin{array}{l}\text { Developer } \\
\text { Country }\end{array}$ & $\begin{array}{c}\text { Trial } \\
\text { Phase }\end{array}$ & Clinical Trial ID & Country & $\begin{array}{l}\text { Enrolment } \\
\text { Target }\end{array}$ & $\begin{array}{l}\text { Actual/Estimated } \\
\text { Trial Dates }\end{array}$ & Primary Outcome Measures \\
\hline 55 & $\begin{array}{l}\text { AdCLD- } \\
\text { CoV19 }\end{array}$ & $\begin{array}{l}\text { Cellid Co., } \\
\text { Ltd. }\end{array}$ & $\begin{array}{l}\text { Viral vector } \\
\text { (non- } \\
\text { replicating) }\end{array}$ & South Korea & $1 / 2$ & NCT04666012 & South Korea & 150 & $\begin{array}{l}29 \text { December 2020- } \\
\text { April } 2022\end{array}$ & $\begin{array}{c}\text { Incidence of SoAEs and } \\
\text { UnSoAEs }\end{array}$ \\
\hline 56 & GLS-5310 & $\begin{array}{l}\text { GeneOne Life } \\
\text { Science Inc }\end{array}$ & $\begin{array}{l}\text { DNA based } \\
\text { vaccine }\end{array}$ & South Korea & $1 / 2$ & NCT04673149 & South Korea & 345 & $\begin{array}{l}23 \text { December 2020- } \\
31 \text { December } 2022\end{array}$ & $\begin{array}{l}\text { Incidence of AEs; GMT of } \\
\text { antigen-specific binding } \\
\text { antibody titres }\end{array}$ \\
\hline 57 & S-268019 & Shionogi & $\begin{array}{l}\text { Protein } \\
\text { subunit }\end{array}$ & Japan & $1 / 2$ & jRCT2051200092 & Japan & 214 & $\mathrm{~N} / \mathrm{A}$ & $\begin{array}{l}\text { AEs, adverse reactions, SAEs, } \\
\text { local and systemic } \\
\text { reactogenicity SoAEs, GMT } \\
\text { of SARS-CoV-2 neutralizing } \\
\text { antibody }\end{array}$ \\
\hline 58 & $\begin{array}{l}\text { SARS-CoV-2- } \\
\text { RBD-Fc- } \\
\text { fusion } \\
\text { protein }\end{array}$ & $\begin{array}{c}\text { University } \\
\text { Medical } \\
\text { Center } \\
\text { Groningen + } \\
\text { Akston } \\
\text { Biosciences } \\
\text { Inc. }\end{array}$ & $\begin{array}{l}\text { Protein } \\
\text { subunit }\end{array}$ & $\begin{array}{l}\text { The } \\
\text { Netherlands }\end{array}$ & $1 / 2$ & NCT04681092 & $\begin{array}{l}\text { The } \\
\text { Netherlands }\end{array}$ & 130 & $\begin{array}{l}12 \text { April 2021- } \\
30 \text { June } 2021\end{array}$ & Safety / Tolerability (35 days) \\
\hline 59 & $\begin{array}{l}\text { COVAC }-1 \text { and } \\
\text { COVAC- } 2\end{array}$ & $\begin{array}{l}\text { University of } \\
\text { Saskatchewan }\end{array}$ & $\begin{array}{l}\text { Protein } \\
\text { subunit }\end{array}$ & Canada & $1 / 2$ & NCT04702178 & Canada & 108 & $\begin{array}{c}10 \text { February } 2021- \\
\text { February } 2023\end{array}$ & $\begin{array}{c}\text { AEs during } 28 \text { days after } \\
\text { each injection }\end{array}$ \\
\hline 60 & COVID-eVax & $\begin{array}{l}\text { Takis }+ \\
\text { Rottapharm } \\
\text { Biotech }\end{array}$ & $\begin{array}{l}\text { DNA based } \\
\text { vaccine }\end{array}$ & Italy & $1 / 2$ & NCT04788459 & Italy & 160 & $\begin{array}{c}25 \text { February } 2021- \\
\text { June } 2022\end{array}$ & $\begin{array}{l}\text { Local and systemic SoAEs, } \\
\text { UnSoAEs, quantitative } \\
\text { antibody titres, binding to the } \\
\text { specific SARS-CoV-2 antigen, } \\
\text { SARS-CoV-2 neutralizing } \\
\text { antibody titre, change from } \\
\text { baseline in antigen-specific } \\
\text { cellular immune responses to } \\
\text { SARS-CoV-2, percentage of } \\
\text { subjects who seroconverted }\end{array}$ \\
\hline
\end{tabular}


Table A2. Cont.

\begin{tabular}{|c|c|c|c|c|c|c|c|c|c|c|}
\hline No & $\begin{array}{l}\text { Vaccine } \\
\text { Candidate }\end{array}$ & Developer & Vaccine Type & $\begin{array}{l}\text { Developer } \\
\text { Country }\end{array}$ & $\begin{array}{c}\text { Trial } \\
\text { Phase }\end{array}$ & Clinical Trial ID & Country & $\begin{array}{c}\text { Enrolment } \\
\text { Target }\end{array}$ & $\begin{array}{l}\text { Actual/Estimated } \\
\text { Trial Dates }\end{array}$ & Primary Outcome Measures \\
\hline 61 & $\begin{array}{l}\text { Inactivated } \\
\text { (NDV based) } \\
\text { chimeric } \\
\text { vaccine }\end{array}$ & $\begin{array}{c}\text { Mahidol } \\
\text { University } \\
\text { and } \\
\text { Government } \\
\text { Pharmaceuti- } \\
\text { cal } \\
\text { Organization }\end{array}$ & $\begin{array}{l}\text { Inactivated } \\
\text { virus }\end{array}$ & Thailand & $1 / 2$ & NCT04764422 & Thailand & 460 & $\begin{array}{l}20 \text { March 2021- } \\
\text { April } 2023\end{array}$ & $\begin{array}{l}\text { Frequency of reportable local } \\
\text { and systemic SoAEs after } \\
\text { each vaccination; } \\
\text { measurement of changes in } \\
\text { hemoglobin, white blood } \\
\text { cells, platelet count, } \\
\text { creatinine, AST, ALT, } \\
\text { bilirubin }\end{array}$ \\
\hline 62 & VBI-2902a & $\begin{array}{l}\text { VBI Vaccines } \\
\text { Inc }\end{array}$ & $\begin{array}{l}\text { Virus like } \\
\text { particle }\end{array}$ & Canada & $1 / 2$ & NCT04773665 & Canada & 780 & $\begin{array}{l}15 \text { March 2021- } \\
\text { June } 2022\end{array}$ & $\begin{array}{c}\text { Rate and severity of local and } \\
\text { systemic SoAEs, UnSoAEs, } \\
\text { MAAEs, SAEs, and } \\
\text { laboratory abnormalities; } \\
\text { AEs leading to } \\
\text { discontinuation of study } \\
\text { vaccination }\end{array}$ \\
\hline 63 & EuCorVac-19 & $\begin{array}{l}\text { POP Biotech- } \\
\text { nologies and } \\
\text { EuBiologics } \\
\text { Co Ltd. }\end{array}$ & $\begin{array}{l}\text { Protein } \\
\text { subunit }\end{array}$ & South Korea & $1 / 2$ & NCT04783311 & South Korea & 280 & $\begin{array}{l}23 \text { February 2021- } \\
\text { January } 2023\end{array}$ & $\begin{array}{c}\text { Immediate AEs, local and } \\
\text { systemic AEs, UnSoAEs, } \\
\text { SAEs, AESIs. }\end{array}$ \\
\hline 64 & DS-5670a & $\begin{array}{l}\text { Daiichi } \\
\text { Sankyo Co } \\
\text { Ltd. }\end{array}$ & $\begin{array}{l}\text { RNA based } \\
\text { vaccine }\end{array}$ & Japan & $1 / 2$ & NCT04821674 & Japan & 152 & $\begin{array}{l}15 \text { March 2021- } \\
31 \text { December } 2022\end{array}$ & $\begin{array}{c}\text { Number of participants } \\
\text { reporting treatment-emergent } \\
\text { AEs, local and systemic AEs, } \\
\text { and SAEs; GMT, GMFR, and } \\
\text { SCR of SARS-CoV-2 specific } \\
\text { neutralizing antibody }\end{array}$ \\
\hline 65 & COVIVAC & $\begin{array}{l}\text { Institute of } \\
\text { Vaccines and } \\
\text { Medical } \\
\text { Biologicals }\end{array}$ & $\begin{array}{l}\text { Viral vector } \\
\text { (non- } \\
\text { replicating) }\end{array}$ & Viet Nam & $1 / 2$ & NCT04830800 & Viet Nam & 420 & $\begin{array}{l}10 \text { March 2021- } \\
30 \text { September } 2022\end{array}$ & $\begin{array}{l}\text { Number and severity of local } \\
\text { and systemic SoAEs, } \\
\text { UnSoAEs, SAEs, MAAEs, } \\
\text { AESIs, and clinically } \\
\text { significant hematological and } \\
\text { biochemical measurements }\end{array}$ \\
\hline
\end{tabular}


Table A2. Cont.

\begin{tabular}{|c|c|c|c|c|c|c|c|c|c|c|}
\hline No & $\begin{array}{l}\text { Vaccine } \\
\text { Candidate }\end{array}$ & Developer & Vaccine Type & $\begin{array}{l}\text { Developer } \\
\text { Country }\end{array}$ & $\begin{array}{l}\text { Trial } \\
\text { Phase }\end{array}$ & Clinical Trial ID & Country & $\begin{array}{l}\text { Enrolment } \\
\text { Target }\end{array}$ & $\begin{array}{l}\text { Actual/Estimated } \\
\text { Trial Dates }\end{array}$ & Primary Outcome Measures \\
\hline 66 & $\begin{array}{l}\text { Recombinant } \\
\text { SARS-CoV-2 } \\
\text { Vaccine }(\mathrm{CHO} \\
\text { Cell) }\end{array}$ & $\begin{array}{l}\text { National } \\
\text { Vaccine and } \\
\text { Serum } \\
\text { Institute }\end{array}$ & $\begin{array}{l}\text { Protein } \\
\text { subunit }\end{array}$ & China & $1 / 2$ & NCT04869592 & China & 3580 & $\begin{array}{l}25 \text { April 2021- } \\
25 \text { October } 2022\end{array}$ & $\begin{array}{l}\text { Incidence and severity of any } \\
\text { adverse reactions/events and } \\
\text { abnormal blood biochemistry, } \\
\text { blood routine, blood } \\
\text { coagulation function and } \\
\text { urine routine, SAEs, AESIs, } \\
\text { GMT of SARS-CoV-2 } \\
\text { neutralizing antibody }\end{array}$ \\
\hline 67 & EXG-5003 & $\begin{array}{c}\text { Elixirgen } \\
\text { Therapeutics } \\
\text { Inc }\end{array}$ & $\begin{array}{l}\text { RNA based } \\
\text { vaccine }\end{array}$ & Japan & $1 / 2$ & NCT04863131 & Japan & 60 & $\begin{array}{l}28 \text { April 2021- } \\
\text { 31 January } 2023\end{array}$ & $\begin{array}{l}\text { Number of participants } \\
\text { reporting local and systemic } \\
\text { AEs }\end{array}$ \\
\hline 68 & KD-414 & $\begin{array}{l}\text { KM Biologics } \\
\text { Co Ltd. }\end{array}$ & $\begin{array}{l}\text { Inactivated } \\
\text { virus }\end{array}$ & Japan & $1 / 2$ & jRCT2071200106 & Japan & 210 & $\mathrm{~N} / \mathrm{A}$ & $\begin{array}{l}\text { Safety: all adverse events and } \\
\text { immunogenicity: } \\
\text { neutralizing antibody } \\
\text { conversion rate against } \\
\text { SARS-CoV-2 }\end{array}$ \\
\hline 70 & QazCovac & $\begin{array}{l}\text { Research } \\
\text { Institute for } \\
\text { Biological } \\
\text { Safety } \\
\text { Problem }\end{array}$ & $\begin{array}{l}\text { Protein } \\
\text { subunit }\end{array}$ & Kazakhstan & $1 / 2$ & NCT04930003 & Kazakhstan & 244 & $\begin{array}{l}15 \text { June } 2021- \\
\text { December } 2021\end{array}$ & $\begin{array}{l}\text { Frequency of AEs for up to } 7 \\
\text { and } 21 \text { days after } \\
\text { immunization. The } \\
\text { proportion of volunteers with } \\
\text { increased levels of the } \\
\text { immune response of specific } \\
\text { neutralizing antibody titres } \\
\text { using ELISA following the } \\
\text { vaccination, compared with } \\
\text { placebo }\end{array}$ \\
\hline 71 & $\begin{array}{l}\text { AG0302- } \\
\text { COVID19 }\end{array}$ & $\begin{array}{l}\text { AnGes, } \\
\text { Inc/Osaka } \\
\text { University }\end{array}$ & $\begin{array}{l}\text { DNA based } \\
\text { vaccine }\end{array}$ & Japan & $1 / 2$ & NCT04993586 & Japan & 400 & $\begin{array}{l}29 \text { July 2021- } \\
31 \text { December } 2021\end{array}$ & $\begin{array}{c}\text { Incidence of } \\
\text { Treatment-Emergent AEs, } \\
\text { immunogenicity }\end{array}$ \\
\hline
\end{tabular}


Table A2. Cont.

\begin{tabular}{|c|c|c|c|c|c|c|c|c|c|c|}
\hline No & $\begin{array}{l}\text { Vaccine } \\
\text { Candidate }\end{array}$ & Developer & Vaccine Type & $\begin{array}{l}\text { Developer } \\
\text { Country }\end{array}$ & $\begin{array}{l}\text { Trial } \\
\text { Phase }\end{array}$ & Clinical Trial ID & Country & $\begin{array}{l}\text { Enrolment } \\
\text { Target }\end{array}$ & $\begin{array}{l}\text { Actual/Estimated } \\
\text { Trial Dates }\end{array}$ & Primary Outcome Measures \\
\hline 72 & Hipra & $\begin{array}{l}\text { Laboratorios } \\
\text { Hipra, S.A. }\end{array}$ & $\begin{array}{l}\text { Protein } \\
\text { subunit }\end{array}$ & Spain & $1 / 2$ & NCT05007509 & Spain & 30 & $\begin{array}{l}16 \text { August 2021- } \\
\text { September } 2022\end{array}$ & $\begin{array}{l}\text { Local and systemic SoAEs } \\
\text { and UnSoAEs }\end{array}$ \\
\hline 73 & $\begin{array}{l}\text { Versamune- } \\
\text { CoV-2FC } \\
\text { vaccine }\end{array}$ & $\begin{array}{c}\text { Farmacore } \\
\text { Biotecnologia } \\
\text { Ltd.a }\end{array}$ & $\begin{array}{l}\text { Protein } \\
\text { subunit }\end{array}$ & Brazil & $1 / 2$ & NCT05016934 & $\mathrm{N} / \mathrm{A}$ & $\mathrm{N} / \mathrm{A}$ & $\begin{array}{l}1 \text { November 2021- } \\
20 \text { April } 2022\end{array}$ & $\begin{array}{l}\text { Frequency and severity of } \\
\text { local and systemic AEs and } \\
\text { AESIs. }\end{array}$ \\
\hline 74 & ARCT-165 & $\begin{array}{c}\text { Arcturus } \\
\text { Therapeutics } \\
\text { Inc }\end{array}$ & $\begin{array}{l}\text { RNA based } \\
\text { vaccine }\end{array}$ & US & $1 / 2$ & NCT05037097 & Singapore, US & 72 & $\begin{array}{l}30 \text { August 2021- } \\
\text { March } 2023\end{array}$ & $\begin{array}{l}\text { Local and systemic SoAEs, } \\
\text { AEs, SAEs, MAAEs, new } \\
\text { onset of chronic disease, } \\
\text { abnormal chemistry and } \\
\text { hematology values; GMT and } \\
\text { GMFR of neutralizing } \\
\text { antibody }\end{array}$ \\
\hline 75 & ARCT-021 & $\begin{array}{l}\text { Arcturus } \\
\text { Therapeutics } \\
\text { Inc }\end{array}$ & $\begin{array}{l}\text { RNA based } \\
\text { vaccine }\end{array}$ & US & $1 / 2$ & NCT05037097 & Singapore, US & 72 & $\begin{array}{l}30 \text { August 2021- } \\
\text { March } 2023\end{array}$ & $\begin{array}{l}\text { Local and systemic SoAEs, } \\
\text { AEs, SAEs, MAAEs, new } \\
\text { onset of chronic disease, } \\
\text { abnormal chemistry and } \\
\text { hematology values; GMT and } \\
\text { GMFR of neutralizing } \\
\text { antibody }\end{array}$ \\
\hline 76 & $\begin{array}{l}\text { SII B.1.351, a } \\
\text { monovalent } \\
\text { (Beta) variant }\end{array}$ & Novavax & $\begin{array}{l}\text { Protein } \\
\text { subunit }\end{array}$ & US & $1 / 2$ & NCT05029856 & Australia & 240 & $\begin{array}{l}\text { February 2022- } \\
\text { August } 2022\end{array}$ & $\begin{array}{c}\text { MN50 GMTs to the } \\
\text { SARS-CoV-2 B.1.351 (Beta) } \\
\text { and B.1.617.2 (Delta), } \\
\text { expressed as GMT and } \\
\text { SCRs/SRRs. Local and } \\
\text { systemic SoAEs, UnSoAEs, } \\
\text { MAAEs }\end{array}$ \\
\hline 77 & $\begin{array}{l}\text { SII Bivalent: } \\
\text { (ancestral } \\
\text { strain and } \\
\text { (Beta) variant) }\end{array}$ & Novavax & $\begin{array}{l}\text { Protein } \\
\text { subunit }\end{array}$ & US & $1 / 2$ & NCT05029856 & Australia & 240 & $\begin{array}{l}\text { February 2022- } \\
\text { August } 2022\end{array}$ & $\begin{array}{c}\text { MN50 GMTs to the } \\
\text { SARS-CoV-2 B.1.351 (Beta) } \\
\text { and B.1.617.2 (Delta), } \\
\text { expressed as GMT and } \\
\text { SCRs/SRRs. Local and } \\
\text { systemic SoAEs, UnSoAEs, } \\
\text { MAAEs }\end{array}$ \\
\hline
\end{tabular}


Table A2. Cont.

\begin{tabular}{|c|c|c|c|c|c|c|c|c|c|c|}
\hline No & $\begin{array}{l}\text { Vaccine } \\
\text { Candidate }\end{array}$ & Developer & Vaccine Type & $\begin{array}{l}\text { Developer } \\
\text { Country }\end{array}$ & $\begin{array}{l}\text { Trial } \\
\text { Phase }\end{array}$ & Clinical Trial ID & Country & $\begin{array}{l}\text { Enrolment } \\
\text { Target }\end{array}$ & $\begin{array}{l}\text { Actual/Estimated } \\
\text { Trial Dates }\end{array}$ & Primary Outcome Measures \\
\hline 78 & $\begin{array}{l}\text { SII B.1.617.2, } \\
\text { monovalent } \\
\text { (Delta) variant }\end{array}$ & Novavax & $\begin{array}{l}\text { Protein } \\
\text { subunit }\end{array}$ & US & $1 / 2$ & NCT05029856 & Australia & 240 & $\begin{array}{l}\text { February 2022- } \\
\text { August } 2022\end{array}$ & $\begin{array}{c}\text { MN50 GMTs to the } \\
\text { SARS-CoV-2 B.1.351 (Beta) } \\
\text { and B.1.617.2 (Delta), } \\
\text { expressed as GMT and } \\
\text { SCRs/SRRs. Local and } \\
\text { systemic SoAEs, UnSoAEs, } \\
\text { MAAEs }\end{array}$ \\
\hline 79 & $\begin{array}{l}\text { AAV5-RBD-S } \\
\text { vaccine } \\
\text { (BCD-250) }\end{array}$ & Biocad & $\begin{array}{l}\text { Viral vector } \\
\quad \text { (non- } \\
\text { replicating) }\end{array}$ & Russia & $1 / 2$ & NCT05037188 & Russia & 160 & $\begin{array}{l}10 \text { August 2021- } \\
\text { December } 2022\end{array}$ & $\begin{array}{l}\text { Percentage of subjects with } \geq \\
4 \text { fold rise of serum } \\
\text { SARS-CoV-2-specific IgG titer } \\
\text { from baseline }\end{array}$ \\
\hline 80 & CoviVac & $\begin{array}{l}\text { Chumakov } \\
\text { Federal } \\
\text { Scientific } \\
\text { Center for } \\
\text { Research and } \\
\text { Development } \\
\text { of Immune- } \\
\text { and-Biological } \\
\text { Products }\end{array}$ & $\begin{array}{l}\text { Inactivated } \\
\text { virus }\end{array}$ & Russia & $1 / 2$ & NCT05046548 & Russia & 400 & $\begin{array}{l}3 \text { October } 2020- \\
1 \text { October } 2021\end{array}$ & Geometric mean titer (GMT) \\
\hline 81 & $\begin{array}{c}\text { VB10.2129, } \\
\text { encoding RBD }\end{array}$ & Vaccibody AS & $\begin{array}{l}\text { DNA based } \\
\text { vaccine }\end{array}$ & Norway & $1 / 2$ & NCT05069623 & Norway & 160 & $\begin{array}{c}27 \text { October 2021- } \\
\text { October } 2023\end{array}$ & $\begin{array}{c}\text { Local and systemic SoAEs, } \\
\text { UnSoAEs, SAEs }\end{array}$ \\
\hline 82 & VB10.2210 & Vaccibody AS & $\begin{array}{l}\text { DNA based } \\
\text { vaccine }\end{array}$ & Norway & $1 / 2$ & NCT05069623 & Norway & 160 & $\begin{array}{l}27 \text { October 2021- } \\
\text { October } 2023\end{array}$ & $\begin{array}{l}\text { Local and systemic SoAEs, } \\
\text { UnSoAEs, SAEs }\end{array}$ \\
\hline 83 & $\begin{array}{l}\text { SARS-CoV-2 } \\
\text { Protein } \\
\text { Subunit } \\
\text { Recombinant } \\
\text { Vaccine }\end{array}$ & Biofarma & $\begin{array}{l}\text { Protein } \\
\text { subunit }\end{array}$ & Indonesia & $1 / 2$ & NCT05067894 & Indonesia & 780 & $\begin{array}{l}\text { November 2021- } \\
\quad \text { March } 2022\end{array}$ & $\begin{array}{l}\text { Safety (phase I) and } \\
\text { immunogenicity (phase II) of } \\
\text { the SARS-CoV-2 protein } \\
\text { subunit recombinant vaccine. }\end{array}$ \\
\hline 84 & $\begin{array}{l}\text { MVA-SARS-2- } \\
\text { S }\end{array}$ & $\begin{array}{l}\text { University of } \\
\text { Munich }\end{array}$ & $\begin{array}{l}\text { Viral vector } \\
\quad \text { (non- } \\
\text { replicating) }\end{array}$ & Germany & 1 & NCT04569383 & Germany & 30 & $\begin{array}{l}\text { October 2020- } \\
\text { May } 2021\end{array}$ & $\begin{array}{l}\text { Percentage of participants } \\
\text { experiencing solicited local or } \\
\text { systemic reactogenicity }\end{array}$ \\
\hline
\end{tabular}


Table A2. Cont.

\begin{tabular}{|c|c|c|c|c|c|c|c|c|c|c|}
\hline No & $\begin{array}{l}\text { Vaccine } \\
\text { Candidate }\end{array}$ & Developer & Vaccine Type & $\begin{array}{l}\text { Developer } \\
\text { Country }\end{array}$ & $\begin{array}{l}\text { Trial } \\
\text { Phase }\end{array}$ & Clinical Trial ID & Country & $\begin{array}{c}\text { Enrolment } \\
\text { Target }\end{array}$ & $\begin{array}{c}\text { Actual/Estimated } \\
\text { Trial Dates }\end{array}$ & Primary Outcome Measures \\
\hline 85 & $\begin{array}{c}\text { LNP- } \\
\text { nCoVsaRNA }\end{array}$ & $\begin{array}{l}\text { Imperial } \\
\text { College } \\
\text { London }\end{array}$ & $\begin{array}{l}\text { RNA based } \\
\text { vaccine }\end{array}$ & UK & 1 & ISRCTN17072692 & UK & 320 & $\begin{array}{l}1 \text { April 2020- } \\
31 \text { July } 2021\end{array}$ & $\begin{array}{c}\text { Solicited local injection site } \\
\text { reactions, solicited systemic } \\
\text { and laboratory reactions, } \\
\text { UnSoAEs, SAEs, titres of } \\
\text { neutralizing antibody and } \\
\text { IgG }\end{array}$ \\
\hline 86 & $\begin{array}{l}\text { Covid- } \\
\text { 19/aAPC }\end{array}$ & $\begin{array}{l}\text { Shenzhen } \\
\text { Geno-Immune } \\
\text { Medical } \\
\text { Institute }\end{array}$ & $\begin{array}{l}\text { Viral vector } \\
\text { (Replicating) }\end{array}$ & China & 1 & NCT04299724 & China & 100 & $\begin{array}{l}15 \text { February 2020- } \\
31 \text { December } 2024\end{array}$ & $\begin{array}{l}\text { Frequency of vaccine events } \\
\text { and serious vaccine events, } \\
\text { proportion of subjects with } \\
\text { positive T cell response }\end{array}$ \\
\hline 87 & AdimrSC-2f & $\begin{array}{l}\text { Adimmune } \\
\text { Corporation }\end{array}$ & $\begin{array}{l}\text { Protein } \\
\text { subunit }\end{array}$ & Taiwan & 1 & NCT04522089 & Taiwan & 70 & $\begin{array}{l}20 \text { August 2020- } \\
20 \text { March } 2021\end{array}$ & $\begin{array}{l}\text { SoAEs and incidence of } \\
\text { abnormal laboratory tests } \\
\text { results }\end{array}$ \\
\hline 88 & $\begin{array}{l}\text { Covigenix } \\
\text { VAX-001 }\end{array}$ & $\begin{array}{l}\text { Entos Pharma- } \\
\text { ceuticals } \\
\text { Inc }\end{array}$ & $\begin{array}{l}\text { DNA based } \\
\text { vaccine }\end{array}$ & Canada & 1 & NCT04591184 & Canada & 72 & $\begin{array}{l}7 \text { April 2021- } \\
\text { August } 2022\end{array}$ & $\begin{array}{l}\text { Safety of a 2-dose regimen of } \\
\text { VAX-001 when doses are } \\
\text { given } 14 \text { days apart, Mean } \\
\text { change from baseline in } \\
\text { safety laboratory measures, } \\
\text { frequency of } \\
\text { treatment-emergent SAEs } \\
\text { throughout the study and up } \\
\text { to } 12 \text { months post-second } \\
\text { dose }\end{array}$ \\
\hline 89 & CORVax & $\begin{array}{l}\text { Providence } \\
\text { Health \& } \\
\text { Services }\end{array}$ & $\begin{array}{l}\text { DNA based } \\
\text { vaccine }\end{array}$ & US & 1 & NCT04627675 & US & 36 & $\begin{array}{l}30 \text { December 2020- } \\
\text { May } 2022\end{array}$ & $\begin{array}{l}\text { Toxicity and MAAEs at } \\
\text { various time frames }\end{array}$ \\
\hline 90 & ChulaCov19 & $\begin{array}{l}\text { Chulalongkorn } \\
\text { University }\end{array}$ & $\begin{array}{l}\text { RNA based } \\
\text { vaccine }\end{array}$ & Thailand & 1 & NCT04566276 & Thailand & 96 & $\begin{array}{l}\text { January 2021- } \\
\text { June } 2021\end{array}$ & $\begin{array}{l}\text { Frequency and grade of AEs, } \\
\text { reportable local and systemic } \\
\text { SoAEs }\end{array}$ \\
\hline 91 & bacTRL-Spike & $\begin{array}{l}\text { Symvivo } \\
\text { corporation }\end{array}$ & $\begin{array}{l}\text { DNA based } \\
\text { vaccine }\end{array}$ & Canada & 1 & NCT04334980 & Australia & 24 & $\begin{array}{l}2 \text { November } 2020- \\
28 \text { February } 2022\end{array}$ & $\begin{array}{l}\text { Frequency of adverse events } \\
\text { up to } 12 \text { months } \\
\text { post-vaccination }\end{array}$ \\
\hline
\end{tabular}


Table A2. Cont.

\begin{tabular}{|c|c|c|c|c|c|c|c|c|c|c|}
\hline No & $\begin{array}{l}\text { Vaccine } \\
\text { Candidate }\end{array}$ & Developer & Vaccine Type & $\begin{array}{l}\text { Developer } \\
\text { Country }\end{array}$ & $\begin{array}{l}\text { Trial } \\
\text { Phase }\end{array}$ & Clinical Trial ID & Country & $\begin{array}{c}\text { Enrolment } \\
\text { Target }\end{array}$ & $\begin{array}{c}\text { Actual/Estimated } \\
\text { Trial Dates }\end{array}$ & Primary Outcome Measures \\
\hline 92 & $\mathrm{COH} 04 \mathrm{~S} 1$ & $\begin{array}{l}\text { City of Hope } \\
\text { Medical } \\
\text { Center }\end{array}$ & $\begin{array}{l}\text { Viral vector } \\
\text { (non- } \\
\text { replicating) }\end{array}$ & US & 1 & NCT04639466 & US & 129 & $\begin{array}{l}11 \text { December } 2020- \\
10 \text { November } 2022\end{array}$ & $\begin{array}{l}\text { Incidence of adverse events } \\
\text { for up to } 365 \text { days }\end{array}$ \\
\hline 93 & MF59 & $\begin{array}{l}\text { The University } \\
\text { of Queensland }\end{array}$ & $\begin{array}{l}\text { Protein } \\
\text { Subunit }\end{array}$ & Australia & 1 & NCT04495933 & Australia & 216 & $\begin{array}{c}13 \text { July 2020- } \\
8 \text { November } 2021\end{array}$ & $\begin{array}{l}\text { Local and systemic SoAEs, } \\
\text { UnSoAEs, SAEs, GMT of the } \\
\text { serum antibody and Nab } \\
\text { response }\end{array}$ \\
\hline 94 & COVIGEN & $\begin{array}{l}\text { The University } \\
\text { of Sydney } \\
\text { Bionet Co., } \\
\text { Ltd. }\end{array}$ & $\begin{array}{l}\text { DNA based } \\
\text { vaccine }\end{array}$ & Australia & 1 & NCT04742842 & Australia & 150 & $\begin{array}{l}15 \text { February 2021- } \\
31 \text { December } 2022\end{array}$ & $\begin{array}{c}\text { Frequency of solicited local } \\
\text { and systemic reactogenicity } \\
\text { AEs, UnSoAEs, SAEs, } \\
\text { MAAEs, change in safety } \\
\text { laboratory values from } \\
\text { baseline }\end{array}$ \\
\hline 95 & BBV154 & Bharat Biotech & $\begin{array}{l}\text { Viral vector } \\
\text { (non- } \\
\text { replicating) }\end{array}$ & India & 1 & NCT04751682 & India & 175 & $\begin{array}{l}1 \text { March 2021- } \\
30 \text { November } 2021\end{array}$ & $\begin{array}{l}\text { Incidence of immediate AEs, } \\
\text { local and systemic SoAEs, } \\
\text { SAEs, and UnSoAEs }\end{array}$ \\
\hline 97 & $\begin{array}{l}\text { CoV2 SAM } \\
\text { (LNP) }\end{array}$ & GlaxoSmithKline & $\begin{array}{l}\text { RNA based } \\
\text { vaccine }\end{array}$ & UK & 1 & NCT04758962 & US & 40 & $\begin{array}{l}15 \text { February 2021- } \\
9 \text { May } 2022\end{array}$ & $\begin{array}{c}\text { Participants with at least } 1 \\
\text { solicited administration site } \\
\text { event and solicited systemic } \\
\text { event, during } 7 \text {-day } \\
\text { follow-up period, with any } \\
\text { UnSoAEs during 30-day } \\
\text { follow-up period after each } \\
\text { vaccination, and with any } \\
\text { hematological and } \\
\text { biochemical laboratory } \\
\text { abnormality at screening, day } \\
1,2,8,31,32 \text {, and } 38 \text {. }\end{array}$ \\
\hline
\end{tabular}


Table A2. Cont.

\begin{tabular}{|c|c|c|c|c|c|c|c|c|c|c|}
\hline No & $\begin{array}{l}\text { Vaccine } \\
\text { Candidate }\end{array}$ & Developer & Vaccine Type & $\begin{array}{l}\text { Developer } \\
\text { Country }\end{array}$ & $\begin{array}{l}\text { Trial } \\
\text { Phase }\end{array}$ & Clinical Trial ID & Country & $\begin{array}{l}\text { Enrolment } \\
\text { Target }\end{array}$ & $\begin{array}{l}\text { Actual/Estimated } \\
\text { Trial Dates }\end{array}$ & Primary Outcome Measures \\
\hline 98 & NBP2001 & $\begin{array}{l}\text { SK Bioscience } \\
\text { Co Ltd. }\end{array}$ & $\begin{array}{l}\text { Protein } \\
\text { subunit }\end{array}$ & South Korea & 1 & NCT04760743 & South Korea & 50 & $\begin{array}{l}17 \text { December 2020- } \\
\text { April } 2022\end{array}$ & $\begin{array}{c}\text { Occurrence of immediate } \\
\text { systemic reactions, local and } \\
\text { systemic SoAEs, UnSoAEs, } \\
\text { SAEs, MAAEs, and AESIs, } \\
\text { GMT and GMFR of IgG and } \\
\text { neutralizing antibody to the } \\
\text { SARS-CoV-2 }\end{array}$ \\
\hline 100 & $\begin{array}{c}\text { SpFN } \\
\text { COVID-19 } \\
\text { Vaccine }\end{array}$ & $\begin{array}{l}\text { Walter Reed } \\
\text { Army Institute } \\
\text { of Research }\end{array}$ & $\begin{array}{l}\text { Protein } \\
\text { subunit }\end{array}$ & US & 1 & NCT04784767 & US & 72 & $\begin{array}{l}5 \text { April 2021- } \\
30 \text { October } 2023\end{array}$ & $\begin{array}{l}\text { Participants with local and } \\
\text { systemic reactions, incidents } \\
\text { of treatment-adverse events } \\
\text { as assessed by FDA toxicity } \\
\text { grading scale, and } \\
\text { participants with humoral } \\
\text { immune response }\end{array}$ \\
\hline 101 & $\begin{array}{l}\text { FAKHRAVAC } \\
\text { (MIVAC) }\end{array}$ & $\begin{array}{l}\text { Organization } \\
\text { of Defensive } \\
\text { Innovation } \\
\text { and Research }\end{array}$ & $\begin{array}{l}\text { Inactivated } \\
\text { virus }\end{array}$ & Iran & 1 & $\begin{array}{l}\text { IRCT20210206- } \\
\text { 050259N1 }\end{array}$ & Iran & 135 & $\mathrm{~N} / \mathrm{A}$ & $\begin{array}{l}\text { Abnormal vital signs and } \\
\text { anaphylactic reactions } \\
\text { immediately after } \\
\text { vaccination, local and } \\
\text { systemic AEs within the first } \\
\text { week post-vaccination, } \\
\text { abnormal laboratory findings }\end{array}$ \\
\hline 102 & MV-014-212 & $\begin{array}{c}\text { Meissa } \\
\text { Vaccines Inc }\end{array}$ & $\begin{array}{c}\text { Live- } \\
\text { Attenuated }\end{array}$ & US & 1 & NCT04798001 & US & 130 & $\begin{array}{l}12 \text { April 2021- } \\
31 \text { October } 2022\end{array}$ & $\begin{array}{c}\text { SoAEs, UnSoAEs, SAEs, } \\
\text { MAAEs, and change in } \\
\text { serum neutralizing antibody } \\
\text { titres against } \\
\text { vaccine-encoded } \\
\text { SARS-CoV-2 S protein }\end{array}$ \\
\hline
\end{tabular}


Table A2. Cont.

\begin{tabular}{|c|c|c|c|c|c|c|c|c|c|c|}
\hline No & $\begin{array}{c}\text { Vaccine } \\
\text { Candidate }\end{array}$ & Developer & Vaccine Type & $\begin{array}{l}\text { Developer } \\
\text { Country }\end{array}$ & $\begin{array}{c}\text { Trial } \\
\text { Phase }\end{array}$ & Clinical Trial ID & Country & $\begin{array}{l}\text { Enrolment } \\
\text { Target }\end{array}$ & $\begin{array}{l}\text { Actual/Estimated } \\
\text { Trial Dates }\end{array}$ & Primary Outcome Measures \\
\hline 103 & $\begin{array}{l}\text { Koçak-19 } \\
\text { Inaktif } \\
\text { Adjuvanlı } \\
\text { COVID-19 } \\
\text { Vaccine }\end{array}$ & Kocak Farma & $\begin{array}{l}\text { Inactivatedviral } \\
\text { vecviral virus }\end{array}$ & Turkey & 1 & NCT04838080 & Turkey & 38 & $\begin{array}{l}19 \text { March 2021- } \\
20 \text { October } 2021\end{array}$ & $\begin{array}{l}\text { AEs, from day } 0 \text { until the end } \\
\text { of follow up period of } 6 \\
\text { months }\end{array}$ \\
\hline 104 & ABNCoV2 & $\begin{array}{l}\text { Radboud } \\
\text { University }\end{array}$ & $\begin{array}{l}\text { Virus like } \\
\text { particle }\end{array}$ & $\begin{array}{l}\text { The } \\
\text { Netherlands }\end{array}$ & 1 & NCT04839146 & $\begin{array}{l}\text { The } \\
\text { Netherlands }\end{array}$ & 42 & $\begin{array}{l}11 \text { March 2021- } \\
20 \text { December } 2021\end{array}$ & $\begin{array}{c}\text { Safety: possibly related } \\
\text { Grade } 3 \text { AEs and SAEs, } \\
\text { Immunogenicity endpoint: } \\
\text { concentration of } \\
\text { ABNCoV2-specific antibodies }\end{array}$ \\
\hline 105 & HDT-301 & $\begin{array}{l}\text { SENAI } \\
\text { CIMATEC }\end{array}$ & $\begin{array}{l}\text { RNA based } \\
\text { vaccine }\end{array}$ & Brazil & 1 & NCT04844268 & $\mathrm{N} / \mathrm{A}$ & 78 & $\begin{array}{l}\text { May 2021- } \\
\text { July } 2022\end{array}$ & $\begin{array}{c}\text { Safety and tolerability of two } \\
\text { doses of HDT- } 1 \text { vaccine (day } \\
1,29 \text { and } 57)\end{array}$ \\
\hline 106 & $\begin{array}{l}\text { Adjuvanted } \\
\text { Inactivated } \\
\text { Vaccine }\end{array}$ & $\begin{array}{l}\text { The Scientific } \\
\text { and } \\
\text { Technological } \\
\text { Research } \\
\text { Council of } \\
\text { Turkey }\end{array}$ & $\begin{array}{l}\text { Inactivated } \\
\text { virus }\end{array}$ & Turkey & 1 & NCT04866069 & Turkey & 50 & $\begin{array}{l}25 \text { April 2021- } \\
\text { April } 2022\end{array}$ & $\begin{array}{l}\text { AAEs, local and systemic } \\
\text { SoAEs and UnSoAEs }\end{array}$ \\
\hline 107 & mRNA-1283 & $\begin{array}{l}\text { ModernaTX, } \\
\text { Inc }\end{array}$ & $\begin{array}{l}\text { RNA based } \\
\text { vaccine }\end{array}$ & US & 1 & NCT04813796 & US & 125 & $\begin{array}{l}11 \text { March 2021- } \\
13 \text { April } 2022\end{array}$ & $\begin{array}{l}\text { Number of participants with } \\
\text { solicited local and systemic } \\
\text { reactogenicity Adverse } \\
\text { Reactions (ARs), UnSoAEs, } \\
\text { and MAAEs, AESIs, and } \\
\text { SAEs }\end{array}$ \\
\hline 108 & $\begin{array}{l}\text { Recombinant } \\
\text { NDV Vectored } \\
\text { Vaccine }\end{array}$ & $\begin{array}{l}\text { Laboratorio } \\
\text { Avi-Mex }\end{array}$ & $\begin{array}{l}\text { Inactivated } \\
\text { virus }\end{array}$ & Mexico & 1 & NCT04871737 & Mexico & 90 & $\begin{array}{l}20 \text { May 2021- } \\
\text { June } 2022\end{array}$ & $\begin{array}{l}\text { AEs, pregnancy test, } \\
\text { urinalysis, oxygen saturation }\end{array}$ \\
\hline 109 & $\begin{array}{l}\text { mRNACOVID- } \\
19 \\
\text { Vaccine }\end{array}$ & $\begin{array}{l}\text { Stemirna } \\
\text { Therapeutics } \\
\text { Co Ltd. and } \\
\text { Shanghai East } \\
\text { Hospital }\end{array}$ & $\begin{array}{l}\text { RNA based } \\
\text { vaccine }\end{array}$ & China & 1 & $\begin{array}{l}\text { ChiCTR21000- } \\
\quad 45984\end{array}$ & China & 30 & $\begin{array}{l}25 \text { March 2021- } \\
25 \text { May } 2022\end{array}$ & Safety and immunogenicity \\
\hline
\end{tabular}


Table A2. Cont.

\begin{tabular}{|c|c|c|c|c|c|c|c|c|c|c|}
\hline No & $\begin{array}{l}\text { Vaccine } \\
\text { Candidate }\end{array}$ & Developer & Vaccine Type & $\begin{array}{l}\text { Developer } \\
\text { Country }\end{array}$ & $\begin{array}{c}\text { Trial } \\
\text { Phase }\end{array}$ & Clinical Trial ID & Country & $\begin{array}{l}\text { Enrolment } \\
\text { Target }\end{array}$ & $\begin{array}{l}\text { Actual/Estimated } \\
\text { Trial Dates }\end{array}$ & Primary Outcome Measures \\
\hline 110 & CoVepiT & $\begin{array}{c}\text { OSE } \\
\text { Immunothera- } \\
\text { peutic }\end{array}$ & $\begin{array}{l}\text { Protein } \\
\text { subunit }\end{array}$ & Belgium & 1 & NCT04885361 & Belgium & 48 & $\begin{array}{l}26 \text { May 2021- } \\
31 \text { March } 2022\end{array}$ & $\begin{array}{l}\text { The incidence of solicited } \\
\text { local and systemic } \\
\text { reactogenicity signs and } \\
\text { symptoms, UnSoAEs, SAEs, } \\
\text { AESIs, subjects with } \\
\text { significantly increased CD8+ } \\
\text { T cells responding to } \\
\text { SARS-CoV-2 }\end{array}$ \\
\hline 111 & CoV2-OGEN1 & USSF/Vaxform & $\begin{array}{l}\text { Protein } \\
\text { subunit }\end{array}$ & US & 1 & NCT04893512 & $\mathrm{N} / \mathrm{A}$ & 45 & $\begin{array}{c}7 \text { June 2021- } \\
15 \text { September } 2022\end{array}$ & $\begin{array}{l}\text { Safety evaluation of 2-dose } \\
\text { vaccination schedule of orally } \\
\text { administered CoV2-OGEN1 } \\
\text { by following local and } \\
\text { systemic adverse events }\end{array}$ \\
\hline 112 & $\begin{array}{c}\text { LNP-nCOV } \\
\text { saRNA-02 } \\
\text { Vaccine }\end{array}$ & $\begin{array}{c}\text { MRC/UVRI } \\
\text { and LSHTM } \\
\text { Uganda } \\
\text { Research Unit }\end{array}$ & $\begin{array}{l}\text { RNA based } \\
\text { vaccine }\end{array}$ & Uganda & 1 & NCT04934111 & Uganda & 42 & $\begin{array}{c}\text { September 2021- } \\
\text { August } 2022\end{array}$ & $\begin{array}{l}\text { Participant with solicited } \\
\text { local injection site and } \\
\text { systemic reactions, UnSoAEs, } \\
\text { SAEs, titre of neutralizing } \\
\text { antibody and IgG }\end{array}$ \\
\hline 113 & $\begin{array}{c}\text { Baiya } \\
\text { SARS-CoV-2 } \\
\text { Vax } 1 \text { Vaccine }\end{array}$ & $\begin{array}{c}\text { Baiya } \\
\text { Phytopharm } \\
\text { Co Ltd. }\end{array}$ & $\begin{array}{l}\text { Protein } \\
\text { subunit }\end{array}$ & Thailand & 1 & NCT04953078 & $\mathrm{N} / \mathrm{A}$ & 96 & $\begin{array}{l}\text { September 2021- } \\
\text { November } 2022\end{array}$ & $\begin{array}{l}\text { Frequency and grade SoAEs } \\
\text { and AEs, change in blood } \\
\text { pressure, pulse rate, } \\
\text { respiratory rate, and physical } \\
\text { condition, safety laboratory } \\
\text { value }\end{array}$ \\
\hline 114 & $\begin{array}{l}\text { PIV5-SARS } \\
\text { CoV-2 }\end{array}$ & CyanVac LLC & $\begin{array}{l}\text { Viral vector } \\
\text { (non- } \\
\text { replicating) }\end{array}$ & US & 1 & NCT04954287 & US & 80 & $\begin{array}{c}\text { July 2021- } \\
\text { November } 2022\end{array}$ & SoAEs, UnSoAEs \\
\hline 115 & $202-\mathrm{CoV}$ & $\begin{array}{l}\text { Shanghai } \\
\text { Zerun } \\
\text { Biotechnology, } \\
\text { Walvax } \\
\text { Biotechnology }\end{array}$ & $\begin{array}{l}\text { Protein } \\
\text { subunit }\end{array}$ & China & 1 & NCT04982068 & China & 144 & $\begin{array}{l}12 \text { July 2021- } \\
\text { October } 2022\end{array}$ & SoAEs, UnSoAEs \\
\hline
\end{tabular}


Table A2. Cont.

\begin{tabular}{|c|c|c|c|c|c|c|c|c|c|c|}
\hline No & $\begin{array}{l}\text { Vaccine } \\
\text { Candidate }\end{array}$ & Developer & Vaccine Type & $\begin{array}{l}\text { Developer } \\
\text { Country }\end{array}$ & $\begin{array}{c}\text { Trial } \\
\text { Phase }\end{array}$ & Clinical Trial ID & Country & $\begin{array}{l}\text { Enrolment } \\
\text { Target }\end{array}$ & $\begin{array}{l}\text { Actual/Estimated } \\
\text { Trial Dates }\end{array}$ & Primary Outcome Measures \\
\hline 116 & COVIDITY & Scancell Ltd. & $\begin{array}{l}\text { DNA based } \\
\text { vaccine }\end{array}$ & UK & 1 & NCT05047445 & South Africa & 40 & $\begin{array}{c}30 \text { September 2021- } \\
\text { June } 2022\end{array}$ & $\begin{array}{l}\text { Safety and tolerability of } \\
\text { COVIDITY as assessed by } \\
\text { AEs, vital signs, and physical } \\
\text { examination }\end{array}$ \\
\hline 117 & $\begin{array}{l}\text { PIKA- } \\
\text { adjuvanted } \\
\text { vaccine }\end{array}$ & $\begin{array}{l}\text { Yisheng } \\
\text { Biopharma }\end{array}$ & $\begin{array}{l}\text { Protein } \\
\text { subunit }\end{array}$ & Singapore & 1 & $\begin{array}{c}\text { ACTRN1262100- } \\
1009808\end{array}$ & $\begin{array}{c}\text { Australia, } \\
\text { New Zealand }\end{array}$ & 45 & $\begin{array}{l}24 \text { September 2021- } \\
13 \text { June } 2022\end{array}$ & $\begin{array}{l}\text { To assess the safety and } \\
\text { tolerability of the PIKA } \\
\text { COVID-19 vaccine by } \\
\text { monitoring AEs and clinical } \\
\text { laboratory tests }\end{array}$ \\
\hline 118 & $\begin{array}{l}\text { SARS-CoV-2 } \\
\text { DNA vaccine }\end{array}$ & $\begin{array}{l}\text { The University } \\
\text { of Hong Kong; } \\
\text { Immuno Cure } \\
3 \text { Limited }\end{array}$ & $\begin{array}{l}\text { DNA based } \\
\text { vaccine }\end{array}$ & Hong Kong & 1 & NCT05102643 & Hong Kong & 30 & $\begin{array}{c}\text { November 2021- } \\
\text { December } 2022\end{array}$ & Reactogenicity and AEs \\
\hline 119 & $\begin{array}{l}\text { Ad5- } \\
\text { triCoV /Mac } \\
\text { or ChAd- } \\
\text { triCoV } / \mathrm{Mac}\end{array}$ & $\begin{array}{l}\text { McMaster } \\
\text { University }\end{array}$ & $\begin{array}{l}\text { Viral vector } \\
\text { (non- } \\
\text { replicating) }\end{array}$ & Canada & 1 & NCT05094609 & Canada & 30 & $\begin{array}{l}9 \text { November 2021- } \\
30 \text { June } 2023\end{array}$ & $\begin{array}{l}\text { Number of participants } \\
\text { reporting AEs and severity of } \\
\text { AEs following vaccination }\end{array}$ \\
\hline 120 & $\begin{array}{l}\text { T-cell priming } \\
\text { specific } \\
\text { peptides on a } \\
\text { gold } \\
\text { nanoparticle }\end{array}$ & $\begin{array}{l}\text { Emergex } \\
\text { Vaccines }\end{array}$ & $\begin{array}{l}\text { Protein } \\
\text { subunit }\end{array}$ & Switzerland & 1 & NCT05113862 & Switzerland & 26 & $\begin{array}{l}\text { December 2021- } \\
\text { November } 2022\end{array}$ & $\begin{array}{l}\text { Local and systemic SoAEs, } \\
\text { UnSoAEs, SAEs, AESIs, } \\
\text { SAEs, MAAEs, AESIs. GMT } \\
\text { and GMFR of } \\
\text { Anti-SAS-CoV-2 RBD IgG } \\
\text { and neutralizing } \\
\text { anti-SARS-CoV-2 }\end{array}$ \\
\hline 121 & IN-B009 & $\begin{array}{l}\text { HK inno.N } \\
\text { Corporation }\end{array}$ & $\begin{array}{l}\text { Protein } \\
\text { subunit }\end{array}$ & South Korea & 1 & NCT05113849 & South Korea & 40 & $\begin{array}{l}16 \text { September 2021- } \\
\text { February } 2023\end{array}$ & $\begin{array}{l}\text { Occurrence of IAR, local and } \\
\text { systemic AE, UnSoAE, }\end{array}$ \\
\hline
\end{tabular}




\section{References}

1. Huang, C.; Wang, Y.; Li, X.; Ren, L.; Zhao, J.; Hu, Y.; Zhang, L.; Fan, G.; Xu, J.; Gu, X.; et al. Clinical features of patients infected with 2019 novel coronavirus in Wuhan, China. Lancet 2020, 395, 497-506. [CrossRef]

2. World Health Organization. WHO Virtual Press Conference on COVID-19. Available online: https://www.who.int/docs/defau lt-source/coronaviruse/transcripts / who-audio-emergencies-coronavirus-press-conference-full-and-final-11mar2020.pdf?sfv rsn=cb432bb3_2 (accessed on 11 March 2020).

3. World Health Organization. Novel Coronavirus 2019. Available online: https:/ / covid19.who.int/ (accessed on 29 November 2021).

4. $\quad$ Sørensen, M.D.; Sørensen, B.; Gonzalez-Dosal, R.; Melchjorsen, C.J.; Weibel, J.; Wang, J.; Jun, C.W.; Huanming, Y.; Kristensen, P. Severe acute respiratory syndrome (SARS): Development of diagnostics and antivirals. Ann. N. Y. Acad. Sci. 2006, 1067, 500-505. [CrossRef] [PubMed]

5. Zumla, A.; Hui, D.S.; Perlman, S. Middle East respiratory syndrome. Lancet 2015, 386, 995-1007. [CrossRef]

6. Lu, R.; Zhao, X.; Li, J.; Niu, P.; Yang, B.; Wu, H.; Wang, W.; Song, H.; Huang, B.; Zhu, N.; et al. Genomic characterisation and epidemiology of 2019 novel coronavirus: Implications for virus origins and receptor binding. Lancet 2020, 395, 565-574. [CrossRef]

7. Gordon, D.E.; Jang, G.M.; Bouhaddou, M.; Xu, J.; Obernier, K.; White, K.M.; O'Meara, M.J.; Rezelj, V.V.; Guo, J.Z.; Swaney, D.L.; et al. A SARS-CoV-2 protein interaction map reveals targets for drug repurposing. Nature 2020, 583, 459-468. [CrossRef] [PubMed]

8. Bosch, B.J.; van der Zee, R.; de Haan, C.A.; Rottier, P.J. The coronavirus spike protein is a class I virus fusion protein: Structural and functional characterization of the fusion core complex. J. Virol. 2003, 77, 8801-8811. [CrossRef]

9. Huang, Y.; Yang, C.; Xu, X.-f.; Xu, W.; Liu, S.-w. Structural and functional properties of SARS-CoV-2 spike protein: Potential antivirus drug development for COVID-19. Acta Pharmacol. Sin. 2020, 41, 1141-1149. [CrossRef]

10. Ou, X.; Liu, Y.; Lei, X.; Li, P.; Mi, D.; Ren, L.; Guo, L.; Guo, R.; Chen, T.; Hu, J.; et al. Characterization of spike glycoprotein of SARS-CoV-2 on virus entry and its immune cross-reactivity with SARS-CoV. Nat. Commun. 2020, 11, 1620. [CrossRef] [PubMed]

11. Xia, S.; Zhu, Y.; Liu, M.; Lan, Q.; Xu, W.; Wu, Y.; Ying, T.; Liu, S.; Shi, Z.; Jiang, S.; et al. Fusion mechanism of 2019-nCoV and fusion inhibitors targeting HR1 domain in spike protein. Cell. Mol. Immunol. 2020, 17, 765-767. [CrossRef]

12. Ju, B.; Zhang, Q.; Ge, J.; Wang, R.; Sun, J.; Ge, X.; Yu, J.; Shan, S.; Zhou, B.; Song, S.; et al. Human neutralizing antibodies elicited by SARS-CoV-2 infection. Nature 2020, 584, 115-119. [CrossRef]

13. Abbasi-Oshaghi, E.; Mirzaei, F.; Farahani, F.; Khodadadi, I.; Tayebinia, H. Diagnosis and treatment of coronavirus disease 2019 (COVID-19): Laboratory, PCR, and chest CT imaging findings. Int. J. Surg. 2020, 79, 143-153. [CrossRef]

14. Lauring, A.S.; Hodcroft, E.B. Genetic Variants of SARS-CoV-2-What Do They Mean? JAMA 2021, 325, 529-531. [CrossRef]

15. Centers for Disease Control and Prevention (CDC). SARS-CoV-2 Variant Classifications and Definitions. Available online: https:/ / www.cdc.gov/coronavirus/2019-ncov/variants/variant-info.html (accessed on 22 November 2021).

16. WHO. Classification of Omicron (B.1.1.529): SARS-CoV-2 Variant of Concern. Available online: https://www.who.int/news/ite m/26-11-2021-classification-of-omicron-(b.1.1.529)-sars-cov-2-variant-of-concern (accessed on 29 November 2021).

17. Wink, P.L.; Zempulski Volpato, F.C.; Monteiro, F.L.; Willig, J.B.; Zavascki, A.P.; Luís Barth, A.; Martins, A.F. First identification of SARS-CoV-2 Lambda (C.37) variant in Southern Brazil. Infect. Control. Hosp. Epidemiol. 2021, 9, 1-2. [CrossRef]

18. WHO. Tracking SARS-CoV-2 Variants. Available online: https://www.who.int/en/activities/tracking-SARS-CoV-2-variants/ (accessed on 22 November 2021).

19. Rambaut, A.; Holmes, E.C.; O’Toole, Á.; Hill, V.; McCrone, J.T.; Ruis, C.; du Plessis, L.; Pybus, O.G. A dynamic nomenclature proposal for SARS-CoV-2 lineages to assist genomic epidemiology. Nat. Microbiol. 2020, 5, 1403-1407. [CrossRef]

20. Walls, A.C.; Park, Y.J.; Tortorici, M.A.; Wall, A.; McGuire, A.T.; Veesler, D. Structure, Function, and Antigenicity of the SARS-CoV-2 Spike Glycoprotein. Cell 2020, 181, 281-292. [CrossRef]

21. Hoffmann, M.; Kleine-Weber, H.; Schroeder, S.; Krüger, N.; Herrler, T.; Erichsen, S.; Schiergens, T.S.; Herrler, G.; Wu, N.H.; Nitsche, A.; et al. SARS-CoV-2 Cell Entry Depends on ACE2 and TMPRSS2 and Is Blocked by a Clinically Proven Protease Inhibitor. Cell 2020, 181, 271-280. [CrossRef] [PubMed]

22. Jonathan, K.; Kosinski-Collins, M.; Sundberg, E. Coronavirus Structure, Vaccine and Therapy Development. Available online: https://web.mit.edu/fnl/volume/324/king_etal.html (accessed on 6 September 2021).

23. Chen, N.; Zhou, M.; Dong, X.; Qu, J.; Gong, F.; Han, Y.; Qiu, Y.; Wang, J.; Liu, Y.; Wei, Y.; et al. Epidemiological and clinical characteristics of 99 cases of 2019 novel coronavirus pneumonia in Wuhan, China: A descriptive study. Lancet 2020, 395, 507-513. [CrossRef]

24. Li, Q.; Guan, X.; Wu, P.; Wang, X.; Zhou, L.; Tong, Y.; Ren, R.; Leung, K.S.M.; Lau, E.H.Y.; Wong, J.Y.; et al. Early Transmission Dynamics in Wuhan, China, of Novel Coronavirus-Infected Pneumonia. N. Engl. J. Med. 2020, 382, 1199-1207. [CrossRef]

25. Lechien, J.R.; Chiesa-Estomba, C.M.; De Siati, D.R.; Horoi, M.; Le Bon, S.D.; Rodriguez, A.; Dequanter, D.; Blecic, S.; El Afia, F.; Distinguin, L.; et al. Olfactory and gustatory dysfunctions as a clinical presentation of mild-to-moderate forms of the coronavirus disease (COVID-19): A multicenter European study. Eur. Arch. Oto-Rhino-Laryngol. 2020, 277, 2251-2261. [CrossRef] [PubMed]

26. Lescure, F.X.; Bouadma, L.; Nguyen, D.; Parisey, M.; Wicky, P.H.; Behillil, S.; Gaymard, A.; Bouscambert-Duchamp, M.; Donati, F.; Le Hingrat, Q.; et al. Clinical and virological data of the first cases of COVID-19 in Europe: A case series. Lancet. Infect. Dis. 2020, 20, 697-706. [CrossRef] 
27. Wu, C.; Chen, X.; Cai, Y.; Xia, J.; Zhou, X.; Xu, S.; Huang, H.; Zhang, L.; Zhou, X.; Du, C.; et al. Risk Factors Associated With Acute Respiratory Distress Syndrome and Death in Patients With Coronavirus Disease 2019 Pneumonia in Wuhan, China. JAMA Intern. Med. 2020, 180, 934-943. [CrossRef]

28. Richardson, S.; Hirsch, J.S.; Narasimhan, M.; Crawford, J.M.; McGinn, T.; Davidson, K.W.; Barnaby, D.P.; Becker, L.B.; Chelico, J.D.; Cohen, S.L.; et al. Presenting Characteristics, Comorbidities, and Outcomes among 5700 Patients Hospitalized with COVID-19 in the New York City Area. JAMA 2020, 323, 2052-2059. [CrossRef] [PubMed]

29. Nath, A. Long-Haul COVID. Neurology 2020, 95, 559-560. [CrossRef] [PubMed]

30. Carfi, A.; Bernabei, R.; Landi, F.; for the Gemelli Against COVID-19 Post-Acute Care Study Group. Persistent Symptoms in Patients After Acute COVID-19. JAMA 2020, 324, 603-605. [CrossRef]

31. Garrigues, E.; Janvier, P.; Kherabi, Y.; Le Bot, A.; Hamon, A.; Gouze, H.; Doucet, L.; Berkani, S.; Oliosi, E.; Mallart, E.; et al. Post-discharge persistent symptoms and health-related quality of life after hospitalization for COVID-19. J. Infect. 2020, 81, e4-e6. [CrossRef] [PubMed]

32. Jabri, A.; Kalra, A.; Kumar, A.; Alameh, A.; Adroja, S.; Bashir, H.; Nowacki, A.S.; Shah, R.; Khubber, S.; Kanaa'N, A.; et al. Incidence of Stress Cardiomyopathy During the Coronavirus Disease 2019 Pandemic. JAMA Netw. Open 2020, 3, e2014780. [CrossRef] [PubMed]

33. Puntmann, V.O.; Carerj, M.L.; Wieters, I.; Fahim, M.; Arendt, C.; Hoffmann, J.; Shchendrygina, A.; Escher, F.; Vasa-Nicotera, M.; Zeiher, A.M.; et al. Outcomes of Cardiovascular Magnetic Resonance Imaging in Patients Recently Recovered From Coronavirus Disease 2019 (COVID-19). JAMA Cardiol. 2020, 5, 1265-1273. [CrossRef] [PubMed]

34. Nalbandian, A.; Sehgal, K.; Gupta, A.; Madhavan, M.V.; McGroder, C.; Stevens, J.S.; Cook, J.R.; Nordvig, A.S.; Shalev, D.; Sehrawat, T.S.; et al. Post-acute COVID-19 syndrome. Nat. Med. 2021, 27, 601-615. [CrossRef]

35. Vincent, M.J.; Bergeron, E.; Benjannet, S.; Erickson, B.R.; Rollin, P.E.; Ksiazek, T.G.; Seidah, N.G.; Nichol, S.T. Chloroquine is a potent inhibitor of SARS coronavirus infection and spread. Virol. J. 2005, 2, 69. [CrossRef]

36. Elavarasi, A.; Prasad, M.; Seth, T.; Sahoo, R.K.; Madan, K.; Nischal, N.; Soneja, M.; Sharma, A.; Maulik, S.K.; Shalimar; et al. Chloroquine and Hydroxychloroquine for the Treatment of COVID-19: A Systematic Review and Meta-analysis. J. Gen. Intern. Med. 2020, 35, 3308-3314. [CrossRef]

37. Horby, P.; Mafham, M.; Linsell, L.; Bell, J.L.; Staplin, N.; Emberson, J.R.; Wiselka, M.; Ustianowski, A.; Elmahi, E.; Prudon, B.; et al. Effect of Hydroxychloroquine in Hospitalized Patients with COVID-19: Preliminary results from a multi-centre, randomized, controlled trial. medRxiv 2020. [CrossRef]

38. FDA. Coronavirus (COVID-19) Update: FDA Revokes Emergency Use Authorization for Chloroquine and Hydroxychloroquine. Available online: https:/ / www.fda.gov/news-events/press-announcements/coronavirus-COVID-19-update-fda-revokes-em ergency-use-authorization-chloroquine-and (accessed on 22 June 2021).

39. Beigel, J.H.; Tomashek, K.M.; Dodd, L.E.; Mehta, A.K.; Zingman, B.S.; Kalil, A.C.; Hohmann, E.; Chu, H.Y.; Luetkemeyer, A.; Kline, S.; et al. Remdesivir for the Treatment of COVID-19-Final Report. N. Engl. J. Med. 2020, 383, 1813-1826. [CrossRef] [PubMed]

40. First COVID-19 Treatment Recommended for EU Authorisation. Available online: https://www.ema.europa.eu/en/news/first -COVID-19-treatment-recommended-eu-authorisation (accessed on 22 June 2021).

41. FDA Approves First Treatment for COVID-19. Available online: https://www.fda.gov/news-events/press-announcements/fdaapproves-first-treatment-COVID-19 (accessed on 22 June 2021).

42. The WHO Rapid Evidence Appraisal for COVID-19 Therapies (REACT) Working Group; Sterne, J.A.C.; Murthy, S.; Diaz, J.V.; Slutsky, A.S.; Villar, J.; Angus, D.C.; Annane, D.; Azevedo, L.C.P.; Berwanger, O.; et al. Association Between Administration of Systemic Corticosteroids and Mortality Among Critically Ill Patients With COVID-19: A Meta-analysis. JAMA 2020, 324, 1330-1341. [CrossRef]

43. NIH. Therapeutic Management of Adults With COVID-19. Available online: https://www.covid19treatmentguidelines.nih.gov /management/therapeutic-management/ (accessed on 22 June 2021).

44. Merck and Ridgeback's Investigational Oral Antiviral Molnupiravir Reduced the Risk of Hospitalization or Death by Approximately 50 Percent Compared to Placebo for Patients with Mild or Moderate COVID-19 in Positive Interim Analysis of Phase 3 Study. Available online: https://www.merck.com/news/merck-and-ridgebacks-investigational-oral-antiviral-molnupiravir-re duced-the-risk-of-hospitalization-or-death-by-approximately-50-percent-compared-to-placebo-for-patients-with-mild-or-m oderat/ (accessed on 15 November 2021).

45. First Oral Antiviral for COVID-19, Lagevrio (Molnupiravir), Approved by MHRA. Available online: https://www.gov.uk/gover nment/news/first-oral-antiviral-for-COVID-19-lagevrio-molnupiravir-approved-by-mhra (accessed on 15 November 2021).

46. Bartoli, A.; Gabrielli, F.; Alicandro, T.; Nascimbeni, F.; Andreone, P. COVID-19 treatment options: A difficult journey between failed attempts and experimental drugs. Intern. Emerg. Med. 2021, 16, 281-308. [CrossRef]

47. Wolff, J.A.; Malone, R.W.; Williams, P.; Chong, W.; Acsadi, G.; Jani, A.; Felgner, P.L. Direct gene transfer into mouse muscle in vivo. Science 1990, 247, 1465-1468. [CrossRef]

48. Pfizer's Novel COVID-19 Oral Antiviral Treatment Candidate Reduced Risk of Hospitalization or Death by $89 \%$ in Interim Analysis of Phase 2/3 Epic-Hr Study. Available online: https://www.pfizer.com/news/press-release/press-release-detail/pfiz ers-novel-COVID-19-oral-antiviral-treatment-candidate (accessed on 15 November 2021).

49. Kayser, V.R.I. A Concise History of Vaccines and Vaccination. Hum. Vaccin. Immunother. 2021, in press. [CrossRef] 
50. Willis, N.J. Edward Jenner and the eradication of smallpox. Scott. Med. J. 1997, 42, 118-121. [CrossRef] [PubMed]

51. Tang, D.C.; DeVit, M.; Johnston, S.A. Genetic immunization is a simple method for eliciting an immune response. Nature 1992, 356, 152-154. [CrossRef] [PubMed]

52. Pronker, E.S.; Weenen, T.C.; Commandeur, H.; Claassen, E.H.J.H.M.; Osterhaus, A.D.M.E. Risk in Vaccine Research and Development Quantified. PLoS ONE 2013, 8, e57755. [CrossRef] [PubMed]

53. Plotkin, S.; Robinson, J.M.; Cunningham, G.; Iqbal, R.; Larsen, S. The complexity and cost of vaccine manufacturing-An overview. Vaccine 2017, 35, 4064-4071. [CrossRef] [PubMed]

54. Regulatory Approval of Pfizer/BioNTech Vaccine for COVID-19. Available online: https://www.gov.uk/government/publicatio ns/regulatory-approval-of-pfizer-biontech-vaccine-for-COVID-19 (accessed on 17 June 2021).

55. FDA Takes Key Action in Fight Against COVID-19 By Issuing Emergency Use Authorization for First COVID-19 Vaccine. Available online: https://www.fda.gov/news-events/press-announcements/fda-takes-key-action-fight-against-COVID-19-is suing-emergency-use-authorization-first-COVID-19 (accessed on 21 June 2021).

56. WHO COVID-19 Vaccine Tracker and Landscape. Available online: https://www.who.int/publications/m/item/draft-landscap e-of-COVID-19-candidate-vaccines (accessed on 6 August 2021).

57. The New York Times Coronavirus Vaccine Tracker. Available online: https://www.nytimes.com/interactive/2020/science/cor onavirus-vaccine-tracker.html (accessed on 6 August 2021).

58. Sabbaghi, A.; Miri, S.M.; Keshavarz, M.; Zargar, M.; Ghaemi, A. Inactivation methods for whole influenza vaccine production. Rev. Med. Virol. 2019, 29, e2074. [CrossRef] [PubMed]

59. Sanders, B.; Koldijk, M.; Schuitemaker, H. Inactivated Viral Vaccines. In Vaccine Analysis: Strategies, Principles, and Control; Nunnally, B.K., Turula, V.E., Sitrin, R.D., Eds.; Springer: Berlin/Heidelberg, Germany, 2015; pp. 45-80.

60. Ramesh, N. Types of Vaccines Infographics. Available online: https:/ / sites.bu.edu/covid-corps/projects/science-communicatio n/types-of-vaccines-infographics / (accessed on 6 September 2021).

61. WHO. Status of COVID-19 Vaccines within WHO EUL/PQ Evaluation Process. Available online: https://www.who.int/teams/ regulation-prequalification/eul/COVID-19 (accessed on 28 June 2021).

62. Al Kaabi, N.; Zhang, Y.; Xia, S.; Yang, Y.; Al Qahtani, M.M.; Abdulrazzaq, N.; Al Nusair, M.; Hassany, M.; Jawad, J.S.; Abdalla, J.; et al. Effect of 2 Inactivated SARS-CoV-2 Vaccines on Symptomatic COVID-19 Infection in Adults: A Randomized Clinical Trial. JAMA 2021, 326, 35-45. [CrossRef] [PubMed]

63. Zhang, M.-X.; Zhang, T.-T.; Shi, G.-F.; Cheng, F.-M.; Zheng, Y.-M.; Tung, T.-H.; Chen, H.-X. Safety of an inactivated SARS-CoV-2 vaccine among healthcare workers in China. Expert Rev. Vaccines 2021, 20, 891-898. [CrossRef]

64. Sinovac. Responses to the SAGE Working Group on COVID-19 Vaccines. Available online: https://www.who.int/publications/i /item/WHO-2019-nCoV-vaccines-SAGE_recommendation-Sinovac-CoronaVac-background-2021.1 (accessed on 21 April 2021).

65. Hansson, M.; Nygren, P.A.; Ståhl, S. Design and production of recombinant subunit vaccines. Biotechnol. Appl. Biochem. 2000, 32, 95-107. [CrossRef]

66. Christensen, D. Vaccine adjuvants: Why and how. Hum. Vaccines Immunother 2016, 12, 2709-2711. [CrossRef]

67. Oxford. Types of Vaccine. Available online: https://vk.ovg.ox.ac.uk/vk/types-of-vaccine (accessed on 12 August 2021).

68. NIH. Vaccine Types. Available online: https://www.niaid.nih.gov/research/vaccine-types (accessed on 12 August 2021).

69. Dai, L.; Gao, G.F. Viral targets for vaccines against COVID-19. Nat. Rev. Immunol. 2021, 21, 73-82. [CrossRef]

70. Ura, T.; Okuda, K.; Shimada, M. Developments in Viral Vector-Based Vaccines. Vaccines 2014, 2, 624-641. [CrossRef]

71. Jackson, D.A.; Symons, R.H.; Berg, P. Biochemical Method for Inserting New Genetic Information into DNA of Simian Virus 40: Circular SV40 DNA Molecules Containing Lambda Phage Genes and the Galactose Operon of Escherichia coli. Proc. Natl. Acad. Sci. USA 1972, 69, 2904-2909. [CrossRef]

72. Vrba, S.M.; Kirk, N.M.; Brisse, M.E.; Liang, Y.; Ly, H. Development and Applications of Viral Vectored Vaccines to Combat Zoonotic and Emerging Public Health Threats. Vaccines 2020, 8, 680. [CrossRef]

73. Voysey, M.; Clemens, S.A.C.; Madhi, S.A.; Weckx, L.Y.; Folegatti, P.M.; Aley, P.K.; Angus, B.; Baillie, V.L.; Barnabas, S.L.; Bhorat, Q.E.; et al. Single-dose administration and the influence of the timing of the booster dose on immunogenicity and efficacy of ChAdOx1 nCoV-19 (AZD1222) vaccine: A pooled analysis of four randomised trials. Lancet 2021, 397, 881-891. [CrossRef]

74. Pottegård, A.; Lund, L.C.; Karlstad, Ø.; Dahl, J.; Andersen, M.; Hallas, J.; Lidegaard, Ø.; Tapia, G.; Gulseth, H.L.; Ruiz, P.L.D.; et al. Arterial events, venous thromboembolism, thrombocytopenia, and bleeding after vaccination with Oxford-AstraZeneca ChAdOx1-S in Denmark and Norway: Population based cohort study. BMJ 2021, 373, n1114. [CrossRef]

75. Wise, J. COVID-19: European countries suspend use of Oxford-AstraZeneca vaccine after reports of blood clots. BMJ 2021, 372, n699. [CrossRef]

76. Baker, A.T.; Boyd, R.J.; Sarkar, D.; Teijeira-Crespo, A.; Chan, C.K.; Bates, E.; Waraich, K.; Vant, J.; Wilson, E.; Truong, C.D.; et al. ChAdOx1 interacts with CAR and PF4 with implications for thrombosis with thrombocytopenia syndrome. Sci. Adv. 2021, 7, eabl8213. [CrossRef] [PubMed]

77. Vogel, F.R.; Sarver, N. Nucleic acid vaccines. Clin. Microbiol. Rev. 1995, 8, 406-410. [CrossRef]

78. Zhang, C.; Maruggi, G.; Shan, H.; Li, J. Advances in mRNA Vaccines for Infectious Diseases. Front. Immunol. 2019, 10, 594. [CrossRef]

79. Rodríguez-Gascón, A.; del Pozo-Rodríguez, A.; Solinís, M.Á. Development of nucleic acid vaccines: Use of self-amplifying RNA in lipid nanoparticles. Int. J. Nanomed. 2014, 9, 1833-1843. [CrossRef] [PubMed] 
80. Silveira, M.M.; Moreira, G.M.S.G.; Mendonça, M. DNA vaccines against COVID-19: Perspectives and challenges. Life Sci. 2021, 267, 118919. [CrossRef] [PubMed]

81. Pardi, N.; Hogan, M.J.; Porter, F.W.; Weissman, D. mRNA vaccines-A new era in vaccinology. Nat. Rev. Drug Discov. 2018, 17, 261-279. [CrossRef] [PubMed]

82. Liu, M.A. A Comparison of Plasmid DNA and mRNA as Vaccine Technologies. Vaccines 2019, 7, 37. [CrossRef] [PubMed]

83. FDA. U.S. Pfizer-BioNTech COVID-19 Vaccine EUA Letter of Authorization Reissued. Available online: https://www.fda.gov/ media/144412/download (accessed on 5 October 2021).

84. FDA. U.S. Pfizer-BioNTech COVID-19 Vaccine. Available online: https:/ / www.fda.gov/emergency-preparedness-and-response/ coronavirus-disease-2019-COVID-19/pfizer-biontech-COVID-19-vaccine (accessed on 18 May 2021).

85. Holm, M.R.; Poland, G.A. Critical aspects of packaging, storage, preparation, and administration of mRNA and adenovirusvectored COVID-19 vaccines for optimal efficacy. Vaccine 2021, 39, 457-459. [CrossRef] [PubMed]

86. Kollewe, J. COVID-19 Vaccines: The Contracts, Prices and Profits. Available online: https://www.theguardian.com/world/2021 /aug/11/COVID-19-vaccines-the-contracts-prices-and-profits (accessed on 12 August 2021).

87. FDA. U.S. Moderna COVID-19 Vaccine EUA Letter of Authorization. Available online: https://www.fda.gov/media/144636/d ownload (accessed on 18 May 2021).

88. FDA. U.S. Moderna COVID-19 Vaccine. Available online: https://www.fda.gov/emergency-preparedness-and-response/corona virus-disease-2019-COVID-19/moderna-COVID-19-vaccine (accessed on 18 May 2021).

89. Santos, A.F.; Gaspar, P.D.; de Souza, H.J.L. Refrigeration of COVID-19 Vaccines: Ideal Storage Characteristics, Energy Efficiency and Environmental Impacts of Various Vaccine Options. Energies 2021, 14, 1849. [CrossRef]

90. Vogel, G.; Kupferschmidt, K. Side effect worry grows for AstraZeneca vaccine. Science 2021, 372, 14. [CrossRef]

91. Torjesen, I. COVID-19: AstraZeneca vaccine is approved in EU with no upper age limit. BMJ 2021, 372, n295. [CrossRef] [PubMed]

92. Dyer, O. COVID-19: Countries are learning what others paid for vaccines. BMJ 2021, 372, n281. [CrossRef]

93. McDougallScientific. 2021 COVID-19 Vaccines: Summary, Updates and Status. Available online: https:/ /www.mcdougallscienti fic.com/wp-content/uploads/2021-COVID-19-Vaccine-and-Clicnial-Trials-Update.pdf (accessed on 12 August 2021).

94. Farooq, U.; Shahzad, A. Pakistan to Start Private Imports of CanSino COVID-19 Vaccine for Sale. Available online: https: //www.reuters.com/article/us-health-coronavirus-pakistan-vaccine-idUSKBN2BE0N3 (accessed on 12 August 2021).

95. WHO. The J\&J COVID-19 Vaccine: What You Need to Know. Available online: https://www.who.int/news-room/feature-storie s/detail/the-j-j-COVID-19-vaccine-what-you-need-to-know (accessed on 18 May 2021).

96. Trefis Team. What's Happening With Johnson \& Johnson's COVID-19 Vaccine? Available online: https://www.forbes.com/sites /greatspeculations/2021/06/09/whats-happening-with-johnson--johnsons-COVID-19-vaccine/?sh=53842c5f1aed (accessed on 12 August 2021).

97. WHO. The Sinopharm COVID-19 Vaccine: What You Need to Know. Available online: https://www.who.int/news-room/featur e-stories / detail/the-sinopharm-COVID-19-vaccine-what-you-need-to-know\#: :text=A\%20large\%20multi\%2Dcountry\%20P hase,efficacy\%20against \%20hospitalization\%20was\%2079\%25. (accessed on 18 May 2021).

98. WHO. Evidence Assessment: Sinopharm/BBIBP COVID-19 Vaccine. Available online: https://cdn.who.int/media/docs/default -source/immunization/sage/2021/april/2_sage29apr2021_critical-evidence_sinopharm.pdf (accessed on 18 May 2021).

99. WHO. COVID-19 Vaccine (Vero Cell), Inactivated (Sinopharm). Available online: https://www.who.int/docs/default-source/co ronaviruse/v.3_21195_sinopharm-vaccine-explainer-24.pdf?sfvrsn=e7507eb4_19\&download=true (accessed on 12 August 2021).

100. Reuters. Hungary Publishes Chinese, Russian Vaccine Contracts Amid COVID-19 Surge. Available online: https://www.reuters. com/article/us-health-coronavirus-hungary-idUSKBN2B30YP (accessed on 12 August 2021).

101. Reuters. Sinovac Coronavirus Vaccine Offered by Chinese City for Emergency Use Costs $\$ 60$. Available online: https://www.re uters.com/article/us-health-coronavirus-china-vaccine-idUSKBN2710UQ (accessed on 12 August 2021).

102. Sputnik, V. The Cost of One Dose of the Sputnik V Vaccine Will be Less Than $\$ 10$ for International Market. Available online: https:/ / sputnikvaccine.com/newsroom/pressreleases/the-cost-of-one-dose-will-be-less-than-10-for-international-mark ets / (accessed on 11 September 2021).

103. Zimmer, C.; Corum, J.; Wee, S.-L. Coronavirus Vaccine Tracker. Available online: https://www.nytimes.com/interactive/2020/s cience/coronavirus-vaccine-tracker.html? (accessed on 15 November 2021).

104. PrecisionVax. EpiVacCorona Vaccine. Available online: https://www.precisionvaccinations.com/vaccines/epivaccorona-vaccine (accessed on 11 September 2021).

105. Kapur, M. For All Its "Made in India" Pitch, Covaxin Is the Most Expensive COVID-19 Vaccine in India. Available online: https: //qz.com/india/2019375/why-does-covaxin-cost-more-than-covishield-and-sputnik-in-india/ (accessed on 11 September 2021).

106. Demesinova, A. Kazakhstan Vaccine against CVI to be Rolled Out in Late April. Available online: https:/ / www.kazpravda.kz/e n/news/society/kazakhstan-vaccine-against-cvi-to-be-rolled-out-in-late-april (accessed on 11 September 2021).

107. He, Q.; Mao, Q.; An, C.; Zhang, J.; Gao, F.; Bian, L.; Li, C.; Liang, Z.; Xu, M.; Wang, J. Heterologous prime-boost: Breaking the protective immune response bottleneck of COVID-19 vaccine candidates. Emerg. Microbes Infect. 2021, 10, 629-637. [CrossRef] [PubMed]

108. Callaway, E. Mix-And-Match COVID Vaccines Trigger Potent Immune Response. Nature 2021, 593, 491. [CrossRef] 
109. Liu, X.; Shaw, R.H.; Stuart, A.S.V.; Greenland, M.; Aley, P.K.; Andrews, N.J.; Cameron, J.C.; Charlton, S.; Clutterbuck, E.A.; Collins, A.M.; et al. Safety and immunogenicity of heterologous versus homologous prime-boost schedules with an adenoviral vectored and mRNA COVID-19 vaccine (Com-COV): A single-blind, randomised, non-inferiority trial. Lancet 2021, 398, 856-869. [CrossRef]

110. Hillus, D.; Schwarz, T.; Tober-Lau, P.; Hastor, H.; Thibeault, C.; Kasper, S.; Helbig, E.T.; Lippert, L.J.; Tscheak, P.; Schmidt, M.L.; et al. Safety, reactogenicity, and immunogenicity of homologous and heterologous prime-boost immunisation with ChAdOx1-nCoV19 and BNT162b2: A prospective cohort study. medRxiv 2021. [CrossRef]

111. Schmidt, T.; Klemis, V.; Schub, D.; Mihm, J.; Hielscher, F.; Marx, S.; Abu-Omar, A.; Schneitler, S.; Becker, S.L.; Gärtner, B.C.; et al. Immunogenicity and reactogenicity of a heterologous COVID-19 prime-boost vaccination compared with homologous vaccine regimens. medRxiv 2021. medRxiv: 2021.06.13.21258859. [CrossRef]

112. CDC. Delta Variant: What We Know About the Science? Available online: https://www.cdc.gov/coronavirus/2019-ncov/varian ts / delta-variant.html (accessed on 15 August 2021).

113. Mahase, E. Delta variant: What is happening with transmission, hospital admissions, and restrictions? BMJ 2021,373 , n1513. [CrossRef]

114. Lopez Bernal, J.; Andrews, N.; Gower, C.; Gallagher, E.; Simmons, R.; Thelwall, S.; Stowe, J.; Tessier, E.; Groves, N.; Dabrera, G.; et al. Effectiveness of COVID-19 Vaccines against the B.1.617.2 (Delta) Variant. N. Engl. J. Med. 2021, 385, 585-594. [CrossRef] [PubMed]

115. Bergwerk, M.; Gonen, T.; Lustig, Y.; Amit, S.; Lipsitch, M.; Cohen, C.; Mandelboim, M.; Levin, E.G.; Rubin, C.; Indenbaum, V.; et al. COVID-19 Breakthrough Infections in Vaccinated Health Care Workers. N. Engl. J. Med. 2021, 385, 1474-1484. [CrossRef]

116. Stephenson, J. COVID-19 Vaccinations in Nursing Home Residents and Staff Give Robust Protection, Though Breakthrough Infections Still Possible. JAMA Health Forum 2021, 2, e211195. [CrossRef]

117. Shrotri, M.; Navaratnam, A.M.D.; Nguyen, V.; Byrne, T.; Geismar, C.; Fragaszy, E.; Beale, S.; Fong, W.L.E.; Patel, P.; Kovar, J.; et al. Spike-antibody waning after second dose of BNT162b2 or ChAdOx1. Lancet 2021, 398, 385-387. [CrossRef]

118. Bar-On, Y.M.; Goldberg, Y.; Mandel, M.; Bodenheimer, O.; Freedman, L.; Kalkstein, N.; Mizrahi, B.; Alroy-Preis, S.; Ash, N.; Milo, R.; et al. Protection of BNT162b2 Vaccine Booster against COVID-19 in Israel. N. Engl. J. Med. 2021, 385, 1393-1400. [CrossRef] [PubMed]

119. Munro, A.P.S.; Janani, L.; Cornelius, V.; Aley, P.K.; Babbage, G.; Baxter, D.; Bula, M.; Cathie, K.; Chatterjee, K.; Dodd, K.; et al. Safety and immunogenicity of seven COVID-19 vaccines as a third dose (booster) following two doses of ChAdOx1 nCov-19 or BNT162b2 in the UK (COV-BOOST): A blinded, multicentre, randomised, controlled, phase 2 trial. Lancet 2021, 398, 2258-2276. [CrossRef]

120. Factbox: Countries Weigh Need for Booster COVID-19 Shots. Available online: https://www.reuters.com/business/healthcarepharmaceuticals / countries-weigh-need-booster-COVID-19-shots-2021-08-05/ (accessed on 15 August 2021).

121. Moscow Begins Booster Vaccine Campaign as Cases Surge. Available online: https://www.reuters.com/business/healthcare-phar maceuticals/moscow-begins-booster-vaccine-campaign-russias-COVID-19-cases-surge-2021-07-01/ (accessed on 15 August 2021).

122. Turkey Offers COVID-19 Booster Shot After Early Use of Chinese Vaccine. Available online: https://www.wsj.com/articles/tur key-offers-COVID-19-booster-shot-after-using-chinese-vaccine-in-early-drive-11625144544 (accessed on 15 August 2021).

123. FDA. Coronavirus (COVID-19) Update: FDA Authorizes Additional Vaccine Dose for Certain Immunocompromised Individuals. Available online: https://www.fda.gov/news-events/press-announcements/coronavirus-COVID-19-update-fda-authorizes -additional-vaccine-dose-certain-immunocompromised (accessed on 15 August 2021).

124. WHO. Interim Statement on COVID-19 Vaccine Booster Doses. Available online: https://www.who.int/news/item/10-08-2021-i nterim-statement-on-COVID-19-vaccine-booster-doses (accessed on 16 August 2021).

125. Tajikistan Declares Mandatory COVID-19 Vaccination. Available online: https://tass.com/world/1310239 (accessed on 15 August 2021).

126. Dyer, O. COVID-19: Turkmenistan becomes first country to make vaccination mandatory for all adults. BMJ 2021, 374, n1766. [CrossRef]

127. Saudi Arabia's Vaccination Rate Spikes as Deadline Approaches. Available online: https://www.bloomberg.com/news/articles/ 2021-07-15/saudi-arabia-s-vaccination-rate-spikes-as-deadline-approaches (accessed on 15 August 2021).

128. Factbox: Countries Making COVID-19 Vaccines Mandatory. Available online: https://www.reuters.com/world/countries-make -COVID-19-vaccines-mandatory-2021-07-13/ (accessed on 15 August 2021).

129. California and New York City to Mandate Vaccine for Government Workers. Available online: https://www.theguardian.com/us-n ews/2021/jul/26/covid-california-new-york-city-department-of-veterans-affairs-vaccine-mandate (accessed on 15 August 2021).

130. Coronavirus: Thousands Protest against Restrictions across Europe. Available online: https://www.dw.com/en/coronavirus-th ousands-protest-against-restrictions-across-europe/a-58627841 (accessed on 15 August 2021).

131. COVAX-Working for Global Equitable Access to COVID-19 Vaccines. Available online: https://www.who.int/initiatives/act-ac celerator/covax (accessed on 24 August 2021).

132. COVAX Vaccine Roll-Out. Available online: https://www.gavi.org/covax-vaccine-roll-out\#country-updates (accessed on 24 August 2021).

133. CEPI. COVAX: CEPI's Response to COVID-19. Available online: https:/ /cepi.net/covax/ (accessed on 24 August 2021). 
134. Director-General's Opening Remarks at the Media Briefing on COVID-19. Available online: https://www.who.int/director-g eneral/speeches/detail/director-general-s-opening-remarks-at-the-media-briefing-on-COVID-19-9-april-2021 (accessed on 4 September 2021).

135. MacDonald, N.E.; Sage Working Group on Vaccine Hesitancy. Vaccine hesitancy: Definition, scope and determinants. Vaccine 2015, 33, 4161-4164. [CrossRef]

136. Durbach, N. 'They Might As Well Brand Us': Working-Class Resistance to Compulsory Vaccination in Victorian England. Soc. Hist. Med. 2000, 13, 45-63. [CrossRef]

137. Patel, M.K.; Orenstein, W.A. Classification of global measles cases in 2013-17 as due to policy or vaccination failure: A retrospective review of global surveillance data. Lancet Glob. Health 2019, 7, e313-e320. [CrossRef]

138. de Figueiredo, A.; Simas, C.; Karafillakis, E.; Paterson, P.; Larson, H.J. Mapping global trends in vaccine confidence and investigating barriers to vaccine uptake: A large-scale retrospective temporal modelling study. Lancet 2020, 396, 898-908. [CrossRef]

139. Smith, T.C. Vaccine Rejection and Hesitancy: A Review and Call to Action. Open Forum Infect. Dis. 2017, 4, ofx146. [CrossRef]

140. Zucker, J.R.; Rosen, J.B.; Iwamoto, M.; Arciuolo, R.J.; Langdon-Embry, M.; Vora, N.M.; Rakeman, J.L.; Isaac, B.M.; Jean, A.; Asfaw, M.; et al. Consequences of Undervaccination-Measles Outbreak, New York City, 2018-2019. N. Engl. J. Med. 2020, 382, $1009-1017$. [CrossRef] [PubMed]

141. Wakefield, A.J.; Murch, S.H.; Anthony, A.; Linnell, J.; Casson, D.M.; Malik, M.; Berelowitz, M.; Dhillon, A.P.; Thomson, M.A.; Harvey, P.; et al. RETRACTED: Ileal-lymphoid-nodular hyperplasia, non-specific colitis, and pervasive developmental disorder in children. Lancet 1998, 351, 637-641. [CrossRef]

142. Taylor, B.; Miller, E.; Farrington, C.; Petropoulos, M.-C.; Favot-Mayaud, I.; Li, J.; Waight, P.A. Autism and measles, mumps, and rubella vaccine: No epidemiological evidence for a causal association. Lancet 1999, 353, 2026-2029. [CrossRef]

143. Kennedy, J. Populist politics and vaccine hesitancy in Western Europe: An analysis of national-level data. Eur. J. Public Health 2019, 29, 512-516. [CrossRef]

144. Germani, F.; Biller-Andorno, N. The anti-vaccination infodemic on social media: A behavioral analysis. PLoS ONE 2021, 16, e0247642. [CrossRef]

145. Zhang, E.J.; Chughtai, A.A.; Heywood, A.; MacIntyre, C.R. Influence of political and medical leaders on parental perception of vaccination: A cross-sectional survey in Australia. BMJ Open 2019, 9, e025866. [CrossRef] [PubMed]

146. Kata, A. Anti-vaccine activists, Web 2.0, and the postmodern paradigm-An overview of tactics and tropes used online by the anti-vaccination movement. Vaccine 2012, 30, 3778-3789. [CrossRef]

147. WHO. Ten Threats to Global Health in 2019. Available online: https://www.who.int/news-room/spotlight/ten-threats-to-globa 1-health-in-2019 (accessed on 18 July 2021).

148. Sarasty, O.; Carpio, C.E.; Hudson, D.; Guerrero-Ochoa, P.A.; Borja, I. The demand for a COVID-19 vaccine in Ecuador. Vaccine 2020, 38, 8090-8098. [CrossRef]

149. Sallam, M.; Dababseh, D.; Eid, H.; Al-Mahzoum, K.; Al-Haidar, A.; Taim, D.; Yaseen, A.; Ababneh, N.A.; Bakri, F.G.; Mahafzah, A. High Rates of COVID-19 Vaccine Hesitancy and Its Association with Conspiracy Beliefs: A Study in Jordan and Kuwait among Other Arab Countries. Vaccines 2021, 9, 42. [CrossRef] [PubMed]

150. Dror, A.A.; Eisenbach, N.; Taiber, S.; Morozov, N.G.; Mizrachi, M.; Zigron, A.; Srouji, S.; Sela, E. Vaccine hesitancy: The next challenge in the fight against COVID-19. Eur. J. Epidemiol. 2020, 35, 775-779. [CrossRef]

151. Robinson, E.; Jones, A.; Lesser, I.; Daly, M. International estimates of intended uptake and refusal of COVID-19 vaccines: A rapid systematic review and meta-analysis of large nationally representative samples. Vaccine 2021, 39, 2024-2034. [CrossRef]

152. Daly, M.; Robinson, E. Willingness to vaccinate against COVID-19 in the US: Longitudinal evidence from a nationally representative sample of adults from April-October 2020. medRxiv 2020. [CrossRef]

153. Roozenbeek, J.; Schneider, C.R.; Dryhurst, S.; Kerr, J.; Freeman, A.L.J.; Recchia, G.; van der Bles, A.M.; van der Linden, S. Susceptibility to misinformation about COVID-19 around the world. R. Soc. Open Sci. 2020, 7, 201199. [CrossRef]

154. Yasmin, F.; Najeeb, H.; Moeed, A.; Naeem, U.; Asghar, M.S.; Chughtai, N.U.; Yousaf, Z.; Seboka, B.T.; Ullah, I.; Lin, C.Y.; et al. COVID-19 Vaccine Hesitancy in the United States: A Systematic Review. Front. Public Health 2021, 9, 770985. [CrossRef] [PubMed]

155. Zhu, F.-C.; Guan, X.-H.; Li, Y.-H.; Huang, J.-Y.; Jiang, T.; Hou, L.-H.; Li, J.-X.; Yang, B.-F.; Wang, L.; Wang, W.-J.; et al. Immunogenicity and safety of a recombinant adenovirus type-5-vectored COVID-19 vaccine in healthy adults aged 18 years or older: A randomised, double-blind, placebo-controlled, phase 2 trial. Lancet 2020, 396, 479-488. [CrossRef]

156. WHO. Strategic Advisory Group of Experts on Immunization (SAGE) COVID-19 Vaccines Technical Documents. Available online: https:/ / www.who.int/groups/strategic-advisory-group-of-experts-on-immunization/COVID-19-materials (accessed on 22 November 2021). 